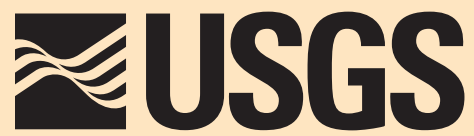

\title{
Spatial and Temporal Variations in Oceanographic and Meteorologic Forcing Along the Central California Coast, 1980-2002
}

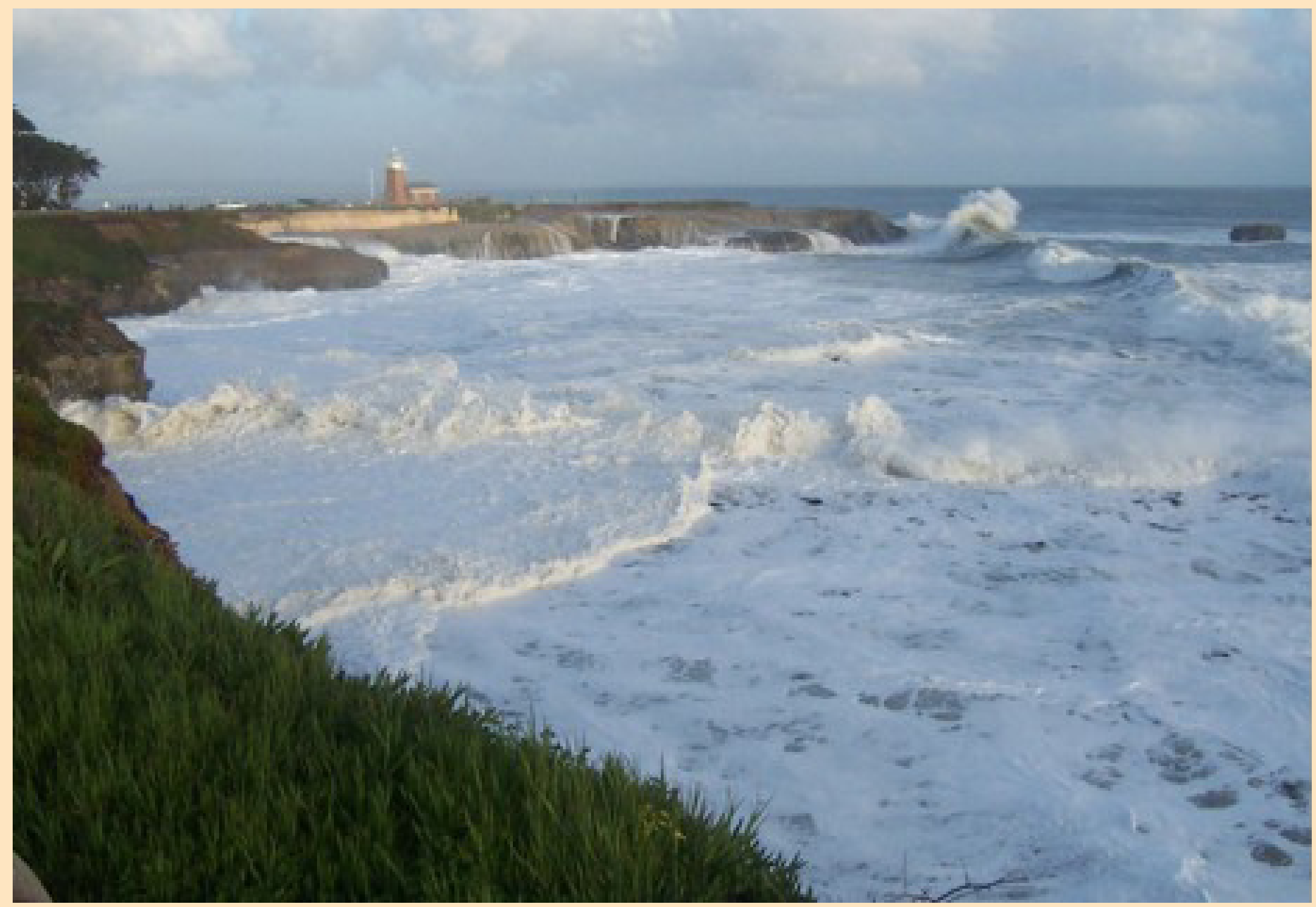

Scientific Investigations Report 2005-5085 


\section{Spatial and Temporal Variations in Oceanographic and Meteorologic Forcing Along the Central California Coast, 1980-2002}

By Curt D. Storlazzi and Dana K. Wingfield

Scientific Investigations Report 2005-5085 


\title{
U.S. Department of the Interior \\ Gale A. Norton, Secretary
}

\author{
U.S. Geological Survey \\ Charles G. Groat, Director
}

U.S. Geological Survey, Reston, Virginia: 2005

For sale by U.S. Geological Survey Information Services

Box 25286, Denver Federal Center

Denver, C0 80225-0046

This report and any updates to it are available online at: http://pubs.usgs.gov/sir/2005/5085/

For additional information write to:

U.S. Geological Survey

Box 25046, Mail Stop 421, Denver Federal Center

Denver, C0 80225-0046

Additional USGS publications can be found at:

http://geology.usgs.gov/products.html

For more information about the USGS and its products:

Telephone: 1-888-ASK-USGS (1-888-275-8747)

World Wide Web: http://www.usgs.gov/

Any use of trade, product, or firm names in this publication is for descriptive purposes only and does not imply endorsement by the U.S. Government.

Although this report is in the public domain, it may contain copyrighted materials that are noted in the text. Permission to reproduce those items must be secured from the individual copyright owners.

\section{Cataloging-in-Publication data are on file with the Library of Congress}

Produced in the Western Region, Menlo Park, California

Manuscript approved for publication, April 26, 2005

Text edited by George A. Havach

Layout and design by Stephen L. Scott 


\section{Contents}

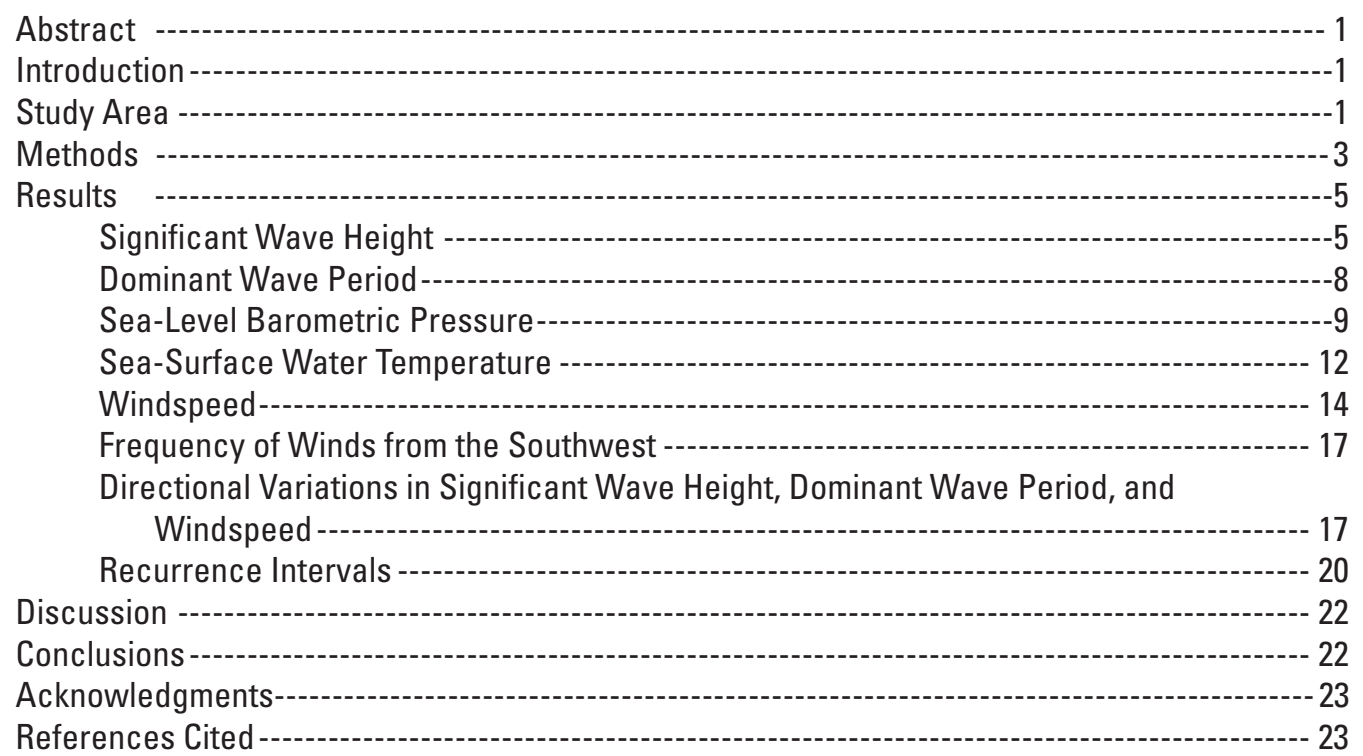

\section{Appendixes}

1. Raw and calculated datasets from eight buoys deployed off the central California the National Oceanic and Atmospheric Administration's National Data Buoy Center over the study period (1980-2002)

2-7. Schematic plots of mean monthly data coverage at eight buoys deployed by the National Oceanic and Atmospheric Administration's National Data Buoy Center buoys over the study period (1980-2002) for:

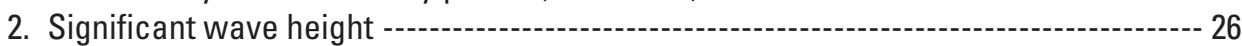

3. Dominant wave period --- 27

4. Sea-level barometric pressure -- 28

5. Sea-surface water temperature ----- 29

6. Windspeed ---:- 30

7. Frequency of winds from the southwest -- 31

8-15. Mean monthly statistics of oceanographic and meteorologic parameters for all months and for El Niño and La Niña months at:

8. Eel River buoy---:- 32

9. Point Arena buoy-- 33

10. Bodega buoy-- 34

11. San Francisco buoy--- 35

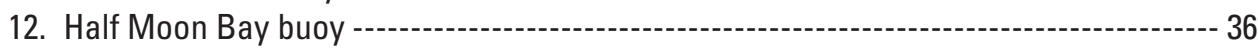

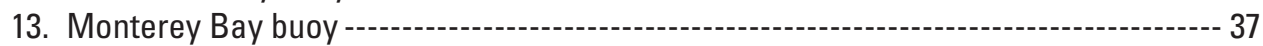

14. Cape San Martin buoy-- 38

15. Point Arguello buoy - 39 


\section{Figures}

1. California, showing the locations of offshore study area and eight buoys deployed off the central coastline by the National Oceanic and Atmospheric Administration's National Data Buoy Center over the study period

2. Bar chart showing data coverage at eight buoys deployed off central California by the National Oceanic and Atmospheric Administration's National Data Buoy

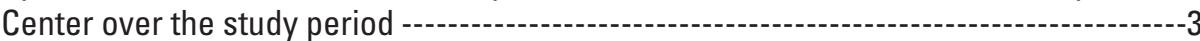

3-21. Plots of:

3. Multivariate El Niño-Southern Oscillation index over the study period --------------------5

4. Monthly variation in mean significant wave height during all months, El Niño months, and La Niña months throughout study area over the study period ------------6

5. Monthly variation in significant wave heights larger than $4 \mathrm{~m}$ during all months, El Niño months, and La Niña months throughout the study area over the study period

6. Monthly variation in significant wave heights larger than $6 \mathrm{~m}$ during all months, El Niño months, and La Niña months throughout the study area over the study period

7. Long-term trends of mean significant wave height throughout the study area over the study period ---

8. Long-term trends of exceedances of significant wave heights larger than $4 \mathrm{~m}$ and larger than $6 \mathrm{~m}$ throughout the study area over the study period --------------9

9. Monthly variation in mean dominant wave period during all months, El Niño months, and La Niña months throughout the study area over the study period -------9

10. Long-term trends of mean dominant wave period throughout the study area over the study period

11. Monthly variation in mean sea-level barometric pressure during all months, El Niño months, and La Niña months throughout the study area over the study period

12. Monthly variation in sea-level barometric pressures lower than 1000 mbars during all months, El Niño months, and La Niña months throughout the study area over the study period

13. Monthly variation in sea-level barometric pressures lower than 990 mbars during all months, El Niño months, and La Niña months throughout the study area over the study period

14. Long-term trends of mean sea-level barometric pressure throughout the study area over the study period

15. Long-term trends of sea-level barometric pressures lower than 1000 mbars throughout the study area over the study period

16. Monthly variation in mean sea-surface water temperature during all months, El Niño months, and La Niña months throughout the study area over the study period

17. Long-term trends of mean sea-surface water temperature throughout the study area over the study period

18. Monthly variation in mean windspeed during all months, El Niño months, and La Niña months throughout the study area over the study period 
19. Long-term trends of mean windspeed throughout the study area over the study period

20. Monthly variation in the frequency of winds from the southwest during all months, El Niño months, and La Niña months throughout the study area over the study period

21. Long-term trends in the frequency of winds from the southwest throughout the study area over the study period--- 17

22-24. Compass plots of:

22. Variation in hourly significant wave height as a function of hourly dominant wave direction at the Monterey Bay buoy during years when concurrent directional wave and wind data were available

23. Variation in hourly dominant wave period as a function of hourly dominant wave direction at the Monterey Bay buoy during years when concurrent directional wave and wind data were available

24. Variation in hourly windspeed as a function of hourly wind direction at the Monterey Bay buoy during years when concurrent directional wave and wind data were available-

25. Bar charts showing frequency distribution of the highest 10 percent of largest hourly significant wave heights as a function of hourly dominant wave direction during El Niño events, La Niña events, and changes in dominant wave direction between two end members, from observations at the Monterey Bay buoy during years when concurrent directional wave and wind data were available

26. Diagram illustrating general wave patterns along the central California coast, synthesized from more than $2,800,000$ hourly observations of significant wave height, dominant wave period, dominant wave direction, windspeed, and wind direction at Monterey Bay buoy during years when concurrent directional wave and wind data were available

\section{Tables}

1. Station data for eight deep-water buoys deployed by the National Oceanic and Atmospheric Administration's National Data Buoy Center along the central California coast since the early 1980s

2. Recurrence-interval projections of maximums of oceanographic and meteorologic parameters

3. Long-term trends of oceanographic and meteorologic parameters throughout the study area over the study period (1980-2002) 


\title{
Spatial and Temporal Variations in Oceanographic and Meteorologic Forcing Along the Central California Coast, 1980-2002
}

\author{
By Curt D. Storlazzi and Dana K. Wingfield
}

\begin{abstract}
Since the 1980s, our understanding of such important large-scale phenomena as El Niño events and the California Current System that drive physical, chemical, and biologic processes along the U.S. west coast has greatly improved. However, our ability to predict the influence of annual and interannual events on a regional scale still remains limited. We have analyzed high-resolution hourly data from eight National Oceanic and Atmospheric Administration buoys deployed since the early 1980s off central California to study spatial and temporal variations in oceanographic and meteorologic forcing along the coast. We identified seasonal to interannual trends in significant wave height, dominant wave period, sea-level barometric pressure, seasurface water temperature, windspeed, and wind direction were identified, as well as significant departures in these trends during El Niño and La Niña periods. The results suggest increasing wave heights and wave periods, decreasing sea-level barometric pressures and variations in sea-surface water temperatures, and increasing variations in windspeed and wind direction off central California between 1980 and 2002.
\end{abstract}

\section{Introduction}

The El Niño events between 1980 and 2002 (most notably in 1982-83 and 1997-98) adversely affected the entire North American Pacific coast (Komar, 1998). Studies by Seymour (1983) and Inman (1991) suggest that winter-storm intensity and the resulting wave heights off southern California are increasing. Allan and Komar (2000) and Bromirski and others (in press) also noted considerable interannual variation in storm-generated wave heights, as well as a general trend of increasing wave heights in the eastern North Pacific, while the area off central California is a "transition zone" from high-energy wave action in the Pacific Northwest to milder wave conditions off southern California. This increase in storminess, as well as in the frequency of storms propagating at lower latitudes across the northeastern Pacific (Brewer and Jackson, 2000), leads to greater coastal erosion, with especially severe shoreline damage during El
Niño years (Seymour and others, 1984; Storlazzi and Griggs, 2000). Schwing and others (2002) observed the evolution of oceanic and atmospheric anomalies (that is, sea-surface water temperature, sea-level barometric pressure, windspeed, and wave height) associated with El Niño/La Niña events in both the Northeast Pacific and the California Current System (CCS). Some studies have focused on the large-scale biologic-physical coupling in the CCS during El Niño years (Chelton and others, 1982; Lynn and others, 1998), and others on smaller, more localized impacts, such as El Niño's effects on processes in Monterey Bay (Griggs and Johnson, 1983; Kudela and Chavez, 2000).

Although our understanding of these important physical phenomena that drive physical, chemical, and biologic processes along the U.S. west coast has improved since 1990, our ability to predict the oceanographic and meteorologic forcing that drives these processes over large spatial and temporal scales in the "transition zone" off central California remains limited. The deployment and continued maintenance of robust operational oceanographic deep-water buoys by the National Oceanic and Atmospheric Administration (NOAA) since the early 1980s provides numerous high-resolution hourly data, such as significant wave height, dominant wave period, windspeed, wind direction, sea-level barometric pressure, air temperature, and sea-surface water temperature. The datasets generated by these systems are now long enough in duration to clearly identify long-term trends and calculate statistically significant probability estimates of the behavior of the measured parameters. In this report, we discuss the spatial and temporal variations in these parameters for eight stations along the central California coast between the Eel River and Point Conception over seasonal to interannual (that is, El Niño and La Niña) climatic cycles.

\section{Study Area}

This study focuses on the 640-km-long central California coast from the Eel River in the north to Point Conception in the south (fig. 1). Central California has a rugged coastline characterized by a narrow continental shelf and coastal mountains cut with high seacliffs and narrow river valleys. The distribution of sediment varies across the shelf. The 
coarsest sediment accumulates in shallow depressions, in the surf zone, and at the shelf break (Anima and others, 2002; Edwards, 2002), and fine to medium sediment offshore to depths of about $20 \mathrm{~m}$, where large volumes of sand generally do not move in response to surface waves during most of the year (Dingler and Reiss, 2002).

The general offshore wave climate of California is characterized by three regimes: Northern Hemisphere swell, Southern swell, and locally wind driven waves (Storlazzi and Griggs, 2000). Northern Hemisphere swell is generated by extratropical cyclones in the North Pacific, generally during the winter months of November through March, when deepwater waves can exceed $8 \mathrm{~m}$ in height (National Marine Consultants, 1960). Southern swell is generated by winter storms in the South Pacific during the Northern Hemisphere's summer or by hurricanes and tropical depressions off Central America during the Northern Hemisphere's summer and early fall. Although Southern swell produces long periods (>20 s) waves, these waves generally are much smaller in height than those produced by Northern Hemisphere swell. Locally wind-driven waves develop rapidly in the winter when low-pressure systems track near central California, or

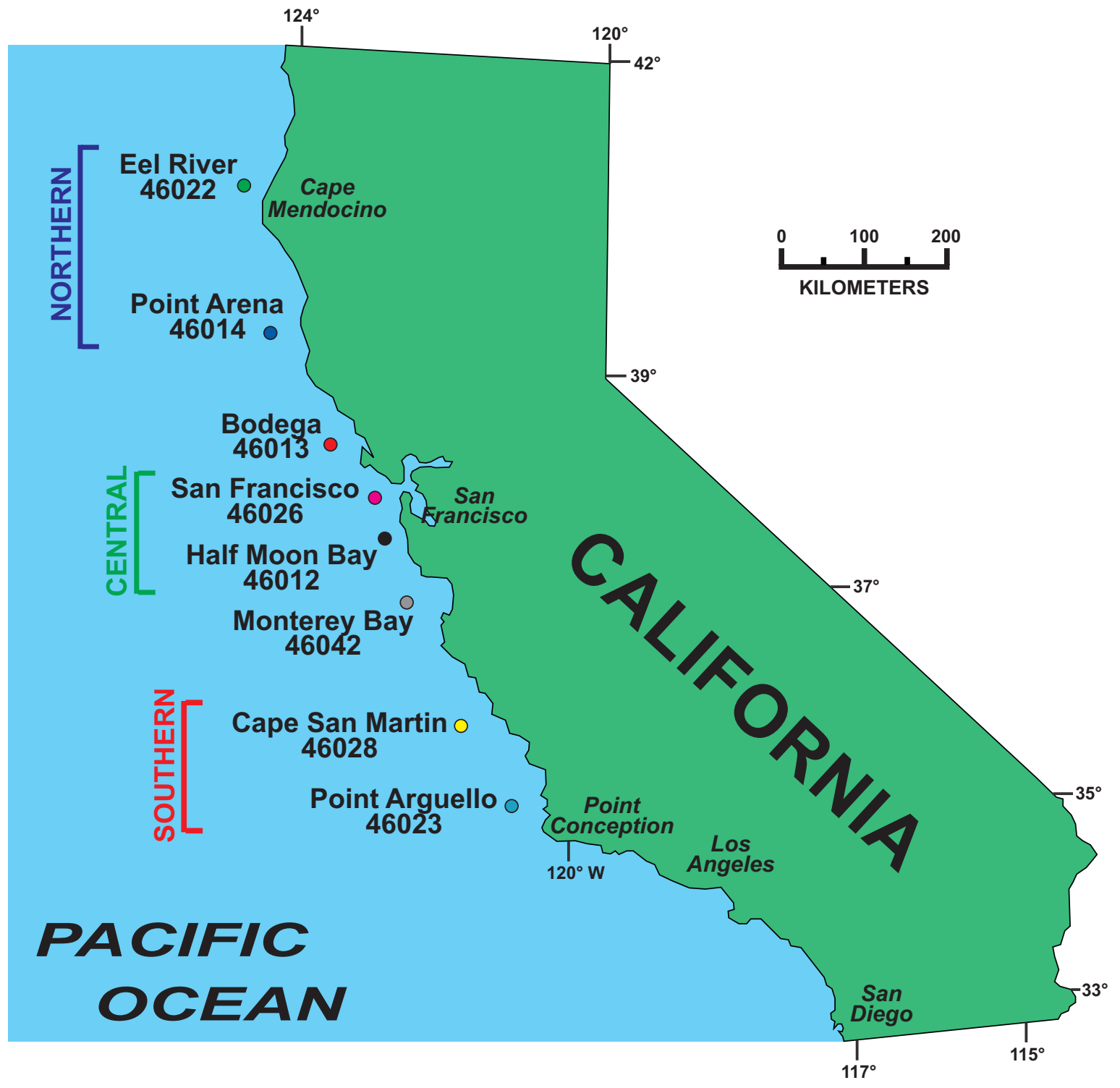

Figure 1. California, showing locations of offshore study area and eight buoys (colored circles) deployed off central coastline by the National Oceanic and Atmospheric Administration's National Data Buoy Center over study period (1980-2002). Colors correspond to individual buoys' data plots in figures 4-6, 9, 11-13, 16, and 18. 
in spring and summer when strong sea breezes are generated (Griggs and Johnson, 1979).

\section{Methods}

Since the early 1980s, NOAA's National Data Buoy Center (NDBC) has deployed several buoys off the U.S. coast to monitor various oceanographic and atmospheric parameters. This study is based on data from eight offshore buoys along the central California coast (fig. 1; table 1). Each buoy is designated with a five-digit, location-specific station number of the style " $460 X X$ ". Datasets are available online at the National Data Buoy Center's (2004) Web site. These buoys record hourly data for various oceanographic and meteorologic parameters, including significant wave height $\left(H_{\text {sig }}\right)$, dominant wave period $\left(T_{\text {dom }}\right)$, dominant wave direction $\left(W V_{\text {dir }}\right)$, sea-level barometric pressure $\left(S L B_{\text {pres }}\right)$, seasurface water temperature $\left(W_{\text {temp }}\right)$, windspeed $\left(W N D_{\mathrm{spd}}\right)$, and wind direction $\left(W N D_{\text {dir }}\right)$. The only buoy equipped to measure $W V_{\text {dir }}$ is the Monterey Bay buoy (sta. 46042), which acquired that capability in the early $1990 \mathrm{~s}$, and so the $W V_{\text {dir }}$ dataset is only 10 years long (1993-2002). Other recorded parameters not discussed here include air temperature (in degrees Celsius), dewpoint temperature, wind-gust speed, average wave period, station visibility, and pressure tendency (in pascals).

After 2 decades of data acquisition, these datasets are now long enough in duration to determine significant patterns and long-term (decadal) trends in these parameters in the study area (fig. 1). To desample and increase the statistical significance of the data, monthly means, minimums, maximums, and standard deviations were calculated for
Table 1. Station data for eight deep-water buoys deployed by the National Oceanic and Atmospheric Administration's National Data Buoy Center along the central California coast since the early 1980s

[See figure 1 for locations. All stations recorded hourly data on significant wave height, dominant wave period, sea-level barometric pressure, sea-surface water temperature, windspeed, and wind direction, except the Monterey Bay buoy, which also recorded dominant wave direction]

\begin{tabular}{ccccc}
\hline Buoy & Station & $\begin{array}{c}\text { Latitude } \\
\mathrm{N} .\end{array}$ & $\begin{array}{c}\text { Longitude } \\
\text { W. }\end{array}$ & $\begin{array}{c}\text { Water depth } \\
(\mathrm{m})\end{array}$ \\
\hline Eel River --------------- & 46022 & $40^{\circ} 43^{\prime} 12^{\prime \prime}$ & $124^{\circ} 31^{\prime} 12^{\prime \prime}$ & 329 \\
Point Arena ---------- & 46014 & $39^{\circ} 13^{\prime} 00^{\prime \prime}$ & $123^{\circ} 57^{\prime} 57^{\prime \prime}$ & 265 \\
Bodega ------------- & 46013 & $38^{\circ} 13^{\prime} 30^{\prime \prime}$ & $123^{\circ} 19^{\prime} 00^{\prime \prime}$ & 123 \\
San Francisco-------- & 46026 & $37^{\circ} 45^{\prime} 32^{\prime \prime}$ & $122^{\circ} 50^{\prime} 00^{\prime \prime}$ & 52 \\
Half Moon Bay------- & 46012 & $37^{\circ} 21^{\prime} 28^{\prime \prime}$ & $122^{\circ} 52^{\prime} 53^{\prime \prime}$ & 88 \\
Monterey Bay -------- & 46042 & $36^{\circ} 45^{\prime} 11^{\prime \prime}$ & $122^{\circ} 25^{\prime} 21^{\prime \prime}$ & 1,920 \\
Cape San Martin ----- & 46028 & $35^{\circ} 44^{\prime} 08^{\prime \prime}$ & $121^{\circ} 53^{\prime} 24^{\prime \prime}$ & 1,112 \\
Point Arguello------- & 46023 & $34^{\circ} 42^{\prime} 50^{\prime \prime}$ & $120^{\circ} 58^{\prime} 00^{\prime \prime}$ & 384 \\
\hline
\end{tabular}

$H_{\text {sig }}, T_{\text {dom }}, S L B_{\text {pres }}, W_{\text {temp }}$, and $W N D_{\text {spd }}$ during each month of the entire study period. Owing to varying buoy-deployment dates, buoy failure, and maintenance operations, however, some gaps exist in the datasets throughout the study period (fig. 2). Initial deployment dates range from 1980 (Half Moon Bay buoy, sta. 46012, fig. 1) to 1987 (Monterey Bay buoy, sta. 46042). Gaps in the datasets due to buoy failure and (or) maintenance range in duration from several weeks to entire seasons. When calculating monthly statistics, sufficient data were required by which to compare various buoys. To obtain equally weighted calculations, months with less

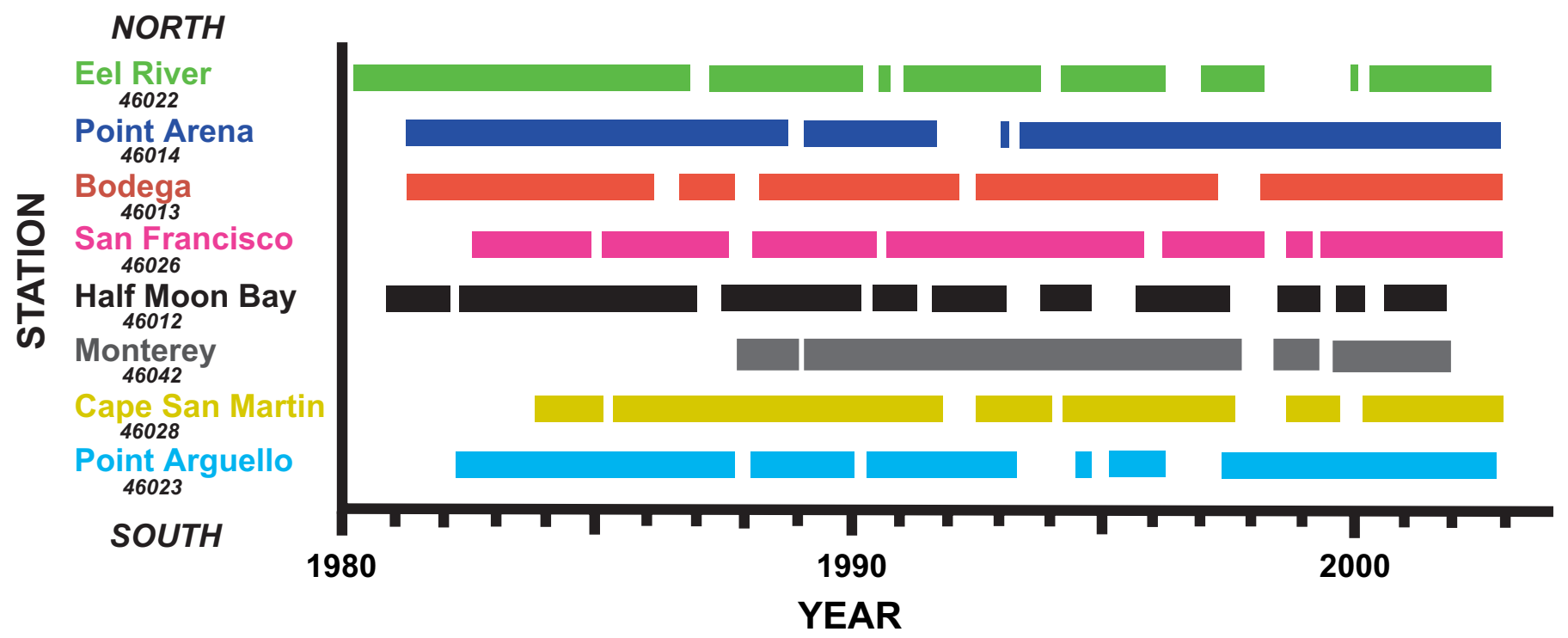

Figure 2. Bar chart showing data coverage at eight buoys deployed off central California (see fig. 1 for locations) by the National 0 ceanic and Atmospheric Administration's National Data Buoy Center over study period (1980-2002). Gaps are due to variations in deployment dates, maintenance periods, and instrument failure. 
than 480 hours (20 days) worth of data were excluded from the analysis.

Monthly exceedances, in terms of the percentage of time over which a parameter was observed to exceed a given value, were determined to identify periods of sustained extreme conditions whose cumulative effects are important for certain physical processes but might not be adequately described by the mean and standard deviation. Monthly exceedances were calculated for $H_{\text {sig }}$ values greater than 4 , 6 , and $8 \mathrm{~m}$ and for $S L B_{\text {pres }}$ values lower than 1000,990 , and 980 mbars for each buoy. In this way, the frequency and magnitude of monthly $H_{\text {sig }}$ and $S L B_{\text {pres }}$ values throughout El Niño events, La Niña events, and months of neither event could be calculated by dividing the number of hours over which the chosen value of $H_{\text {sig }}$ and (or) $S L B_{\text {pres }}$ was exceeded during a given month by the total number of recorded hours of observation during that month.

Wind directions along the central California coast are typically from the west-northwest at azimuths $270-359^{\circ}$ (Inman and Jenkins, 1997), driven by a region of high pressure, termed the "California High" that generally resides off northern California during the spring and summer. Observations of wind directions at (blowing from) azimuths $070-250^{\circ}$ were of particular interest because these directions would be counter to the normal wind direction. The frequency of winds from the southwest $\left(W N D_{\text {wsw }}\right)$, in combination with Ekman steering, drives warm surface water onshore and downward, causing "downwelling" at the coastline. This parameter has been shown by numerous workers to be significant to many physical processes along the U.S. west coast (Inman and Jenkins, 1997; Storlazzi and Griggs, 2000; Storlazzi and others, 2003, 2004). Monthly means, minimums, maximums, and standard deviations of $W N D_{\text {wsw }}$ were also calculated.

Once calculated, monthly statistics were separated into three parts of the study area (fig. 1): northern (Eel River buoy, sta. 46022, and Point Arena buoy, sta. 46014), central (San Francisco buoy, sta. 46026, and Half Moon Bay buoy, sta. 46012), and southern (Cape San Martin buoy, sta. 46028, and Point Arguello buoy, sta. 46023). Data from the Bodega buoy (sta. 46013) and the Monterey Bay buoy (sta. 46042) were omitted so that the calculations for part of the study area were based on the same number of buoys. The data from each buoy were equally weighted and averaged together to give values for each oceanographic and atmospheric parameter in each part of the study area. The minimum, maximum, mean, standard deviation, observed exceedances, and long-term trends of each parameter were then determined for each part of the study area.

From recurrence-interval projections and calculated extreme values, the average time between events of a given magnitude can be estimated (Carter and others, 1986). For example, a 2-year recurrence interval for $H_{\text {sig }}$ suggests that the probability of an occurrence of a given extreme value is once every 2 years. The inverse, or reciprocal, of the recurrence interval is the probability of such an occurrence equaling or exceeding the given extreme value. Return magnitudes were based on Fisher-Tippet type I distributions (Carter and others, 1986) of monthly maximums, and 2-, 10-, 50-, and 100-year return-magnitude projections were calculated for $H_{\text {sig }}, T_{\text {dom }}, S L B_{\text {pres }}, W_{\text {temp }}$, and $W N D_{\text {spd. }}$.

The El Niño-Southern Oscillation (ENSO) cycle is an interannual phenomenon composed of episodic El Niño and La Niña climatic events. The Southern Oscillation index (SOI), which is a proxy measure used to determine the presence and strength of an ENSO event, is the quantitative difference in the pressure centers of Tahiti, French Polynesia (generally a region of low sea-level barometric pressure), and Darwin, Australia (typically a region of high sea-level barometric pressure). These two opposite ends of the Southern Oscillation create a pressure gradient that is used to characterize warm and cold ENSO phases (Glantz, 2001). A negative SOI phase represents an El Niño event, in which below-average barometric pressures occur at Tahiti and above-average barometric pressures at Darwin, whereas a positive SOI phase represents a La Niña event and reverse barometric pressure gradients, respectively (Glantz, 2001).

Although the SOI is derived specifically from barometric-pressure anomalies, the multivariate ENSO index (MEI), devised by Wolter and Timlin (1998), incorporates multiple factors to give a weighted average of the main oceanic-atmospheric ENSO-related features. In addition to sea-level barometric pressure, other variables include sea-surface water temperature, surface air temperature, total cloudiness, and zonal (north-south) and meridional (east-west) components of surface winds. The MEI (fig. 3) is read opposite to the SOI, with negative values representing cold ENSO phases (La Niña) and positive values representing warm ENSO phases (El Niño).

To understand how these oceanographic and meteorologic parameters are influenced by ENSO events, we broke down the monthly statistics into three categories based on the corresponding MEIs for each specific month: all months of the study period, El Niño months, and La Niña months. Monthly MEIs before 1993 were normalized to an average MEI of 0.0 and a standard deviation of 1.0 (National Oceanic and Atmospheric Administration, Climate Diagnostics Center, 2004). Cutoff MEIs were used to separate index values of El Niño, La Niña, and "normal" months, that is, months when neither El Niño nor La Niña conditions were observed. Any month when the MEI was greater than 1.0 was defined as an El Niño month, any month when the MEI was less than -0.5 as a La Niña month, and any month when the MEI was less than 1.0 but greater than -0.5 as a normal month. The monthly mean, standard deviation of the mean, and mean of the standard deviation of $H_{\text {sig }}, T_{\text {dom }}, S L B_{\text {pres }}, W_{\text {temp }}, W N D_{\text {spd }}$, and $W N D_{\text {wsw }}$ were matched with their corresponding monthly MEIs. In this way, monthly numeric MEI intensities could be assigned with concurrent buoy data to categorize the oceanic and atmospheric parameters into El Niño months, La Niña months, or normal months. 


\section{Results}

\section{Significant Wave Height}

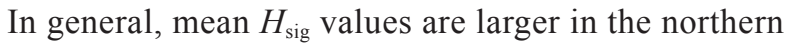
part of the study area (fig. 1) and smaller in the southern part. A significant deviation from this trend is visible on the San Francisco buoy's (sta. 46026) wave record, which on average is much lower than those of the surrounding buoys. These smaller-than-average $H_{\text {sig }}$ values are due to this buoy's location on the inner part (50-m depth) of the broadest section of the Continental Shelf in the study area. By the time these waves reach the San Francisco buoy, they have

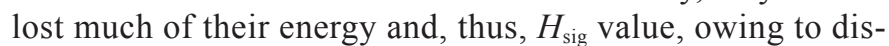
sipation of wave energy as they interact with the sea floor in the shallower parts of the Continental Shelf. Seasonally, mean $H_{\text {sig }}$ values are largest during the winter (November-February), ranging from 2.74 to $3.09 \mathrm{~m}$ in the northern part of the study area and from 2.31 to $2.50 \mathrm{~m}$ in the southern part (fig. 4A; see apps. 2, 8-15). Spatial trends show an increasing wave-climate variation during the winter, with mean $H_{\text {sig }}$ values 0.35 to $0.59 \mathrm{~m}$ larger in the northern part of the study area than in the southern part. During the summer (June-August), mean $H_{\text {sig }}$ values are generally smaller, ranging from 1.62 to $1.96 \mathrm{~m}$ in the northern part of the study area and from 1.72 to $2.02 \mathrm{~m}$ in the southern part.

Mean $H_{\text {sig }}$ values range from 0.26 to $1.16 \mathrm{~m}$ larger during El Niño winter months than during normal winter months (fig. 4B). During the El Niño month of February, mean $H_{\text {sig }}$ are largest in all parts of the study area (fig. 1): almost $0.5 \mathrm{~m}$ larger ( $1.16 \mathrm{~m}$ larger than average) in the northern part of the study area than in the southern part ( $0.70 \mathrm{~m}$ larger than average). Mean $H_{\text {sig values during El }}$ Niño summer months vary less than during the winter. Mean $H_{\text {sig }}$ values are lowest in May ( $0.44 \mathrm{~m}$ smaller than average).

Although mean $H_{\text {sig }}$ values are larger than normal during La Niña winter months, they are only 0.04 to $0.36 \mathrm{~m}$ larger than average (fig. $4 \mathrm{C}$ ). Mean $H_{\text {sig values are largest }}$ during the La Niña month of November, when they are 0.18 $\mathrm{m}$ larger than average in the southern part of the study area $0.15 \mathrm{~m}$ larger than average in the northern part. Mean $H_{\text {sig }}$

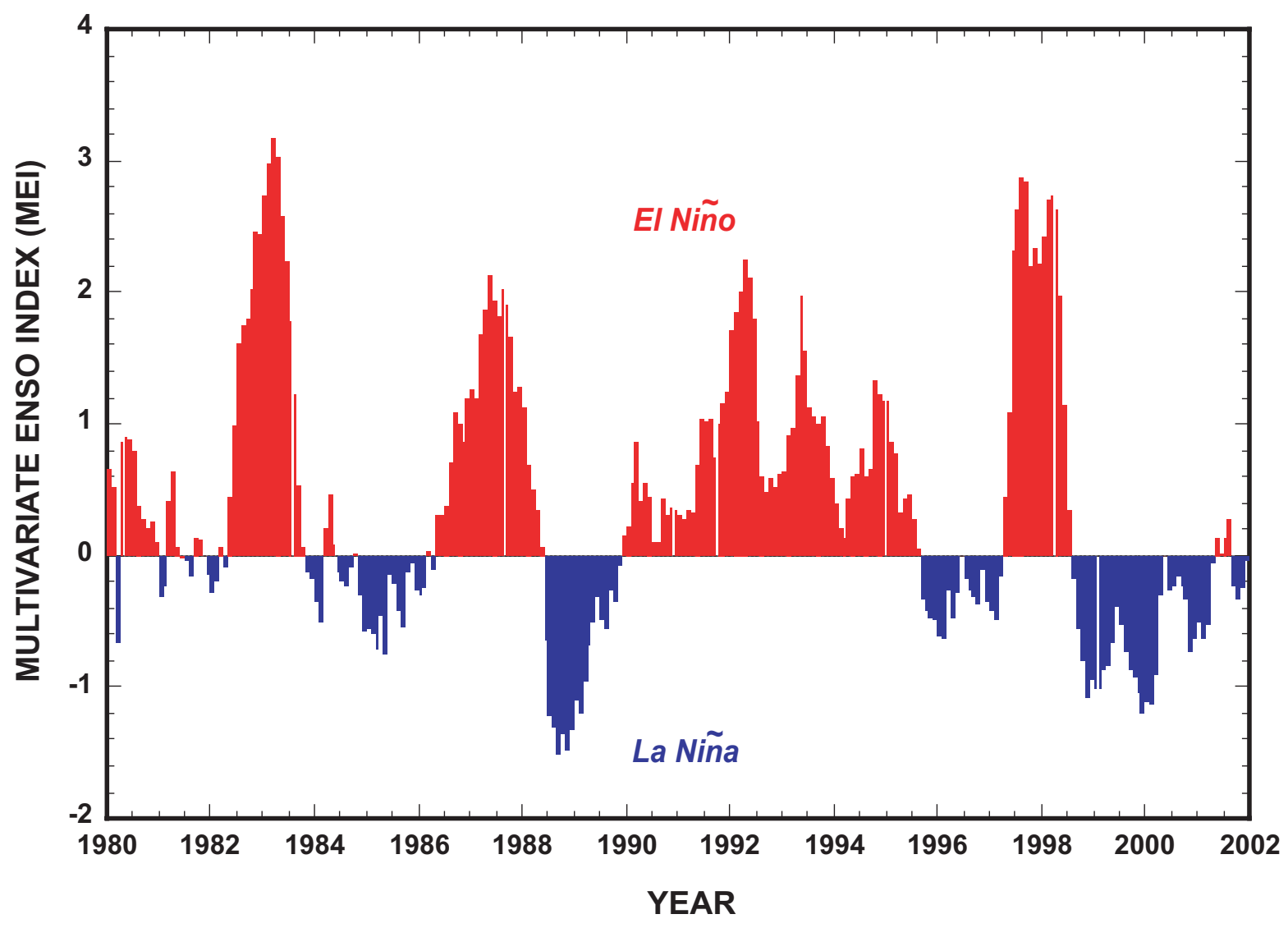

Figure 3. Multivariate El Niño-Southern Oscillation (ENSO) index (MEI) over study period (1980-2002). MEl is opposite of the Southern Oscillation index, with negative (blue) values representing cold ENSO phases (La Niña conditions) and positive (red) values representing warm ENSO phases (El Niño conditions). 
values during La Niña summer months are typically smaller than during normal summer months, ranging from $0.25 \mathrm{~m}$ smaller than average to only $0.19 \mathrm{~m}$ larger than average.

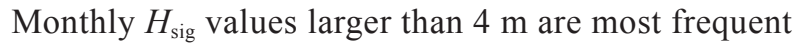
in the northern part of the study area (figs. 1, 5A) in December, when they make up as much as 21.64 percent of total monthly $H_{\text {sig }}$ values observations. In contrast, monthly $H_{\text {sig }}$ values larger than $4 \mathrm{~m}$ are most frequent in the southern part of the study area in March, when they make up as much as 11.41 percent of total monthly $H_{\text {sig }}$ observations.

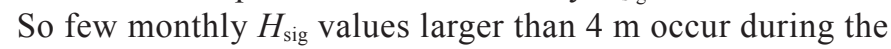
summer that they are not statistically significant.

Throughout the study period, monthly $H_{\text {sig }}$ values larger than $4 \mathrm{~m}$ are most frequent during El Niño winter months (November-February, fig. $5 B$ ): as much as 32.08 percent more frequent than average in the northern part of the study area (fig. 1) and as much as 14.59 percent more frequent than average in the southern part. Monthly $H_{\text {sig }}$ values larger than $4 \mathrm{~m}$ are less frequent and vary less during La Niña

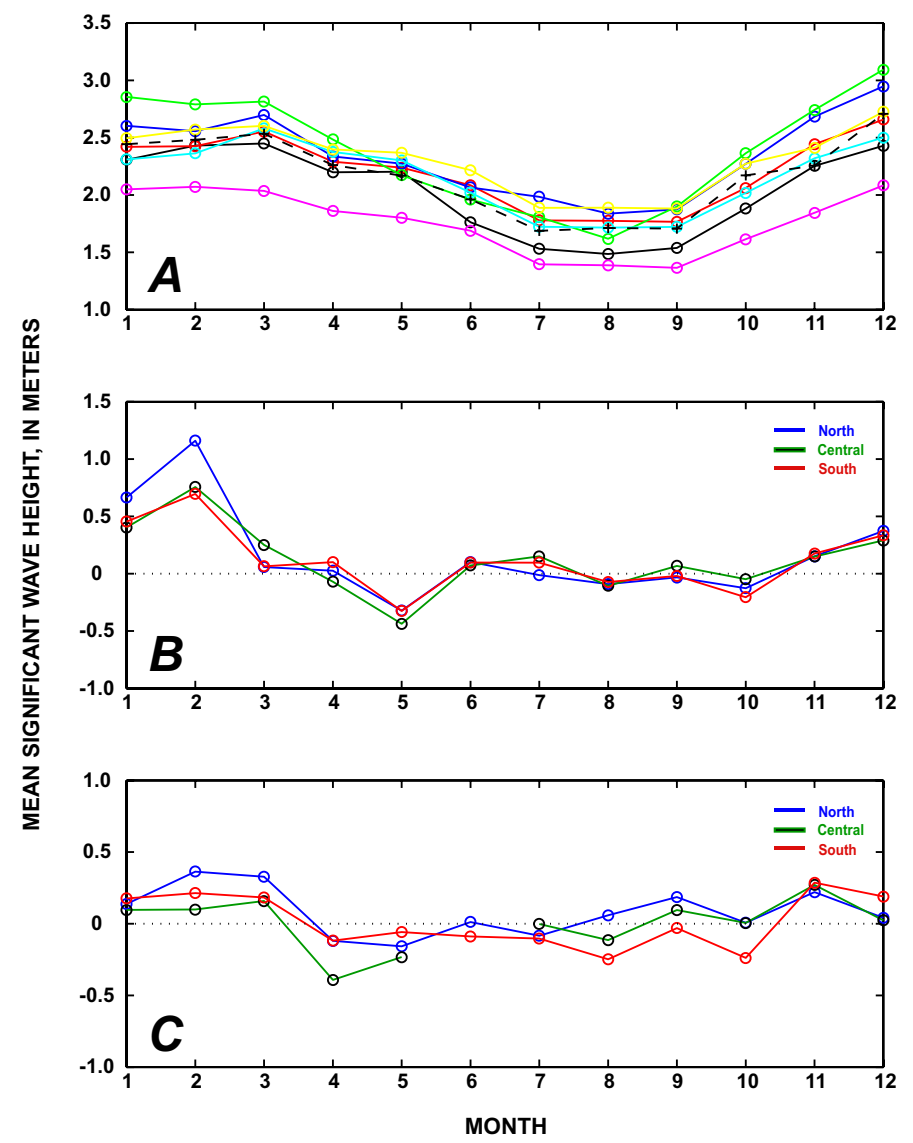

Figure 4. Monthly variation in mean significant wave height $\left(H_{\text {sig }}\right)$ during all months $(A)$, during El Niño months $(B)$, and during La Niña months $(C)$ throughout study area (fig. 1) over study period (19802002). Colored curves in figure $4 A$ correspond to individual buoys located in figure 1 . Note that mean $H_{\text {sig }}$ values are typically largest during El Niño winter months. winters than during El Niño winters (fig. $5 C$ ). As during El Niño winter months, monthly $H_{\text {sig }}$ values larger than $4 \mathrm{~m}$ are most frequent in February, ranging from 4.45 percent more frequent in the southern part of the study area to as much as 9.70 percent more frequent in the northern part.

Monthly $H_{\text {sig }}$ values larger than $6 \mathrm{~m}$ during normal, non-ENSO periods are most frequent in the early winter (December), when they make up 2.63 percent of total monthly $H_{\text {sig }}$ values in the northern part of the study area (figs. 1, 6A). During El Niño winter months, monthly $H_{\text {sig }}$ values larger than $6 \mathrm{~m}$ are most frequent in February, ranging from 1.20 percent more frequent than average in the southern part of the study area to 3.98 percent more frequent than average in the northern part (fig. 6B). Whereas El Niño monthly $H_{\text {sig }}$ values larger than $6 \mathrm{~m}$ are most frequent during the late winter, La Niña monthly $H_{\text {sig }}$ values larger than $6 \mathrm{~m}$ are most frequent in the early winter. For example, during the La Niña month of December they are as much as 1.31 percent more frequent than average in the

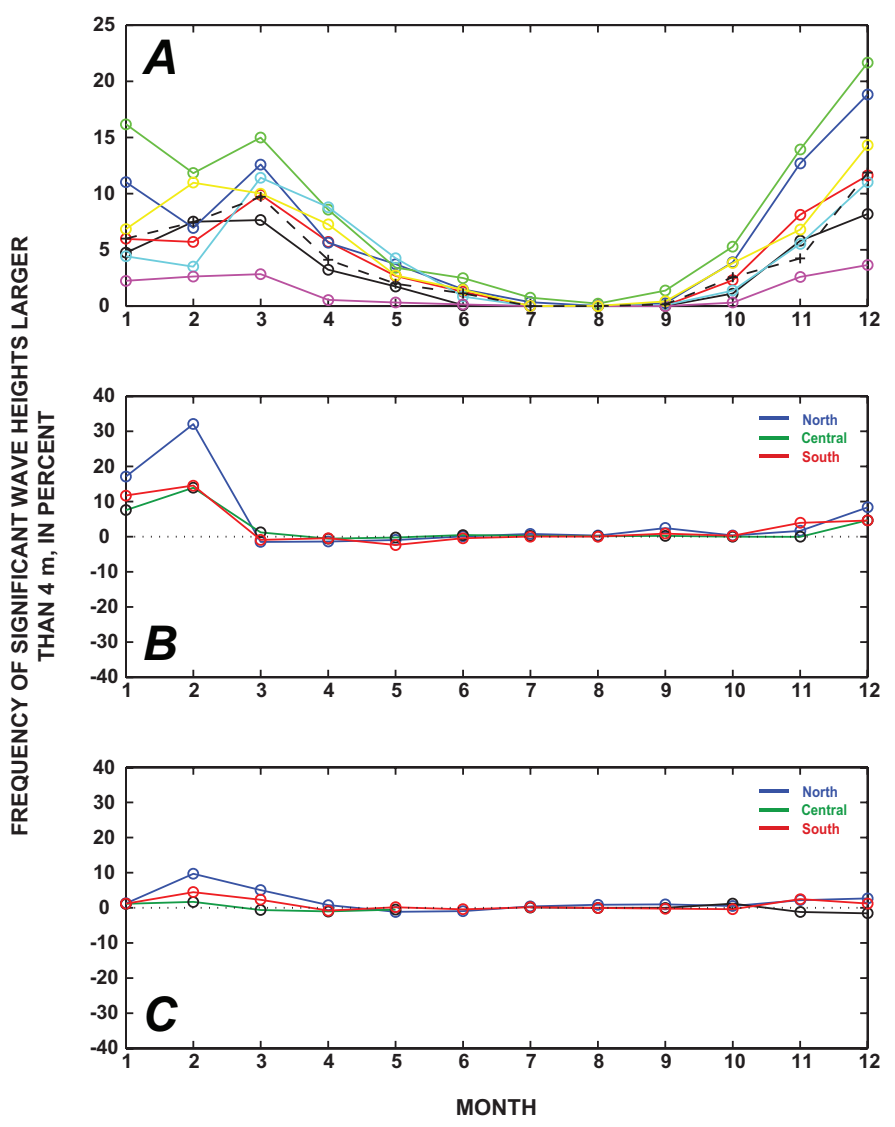

Figure 5. Monthly variation in significant wave heights $\left(H_{\text {sig }}\right)$ larger than $4 \mathrm{~m}$ during all months $(A)$, during El Niño months $(B)$, and during La Niña months $(C)$ throughout study area (fig. 1) over study period (1980-2002). Colored curves in figure $5 A$ correspond to individual buoys located in figure 1 . Note that $H_{\text {sig }}$ values larger than $4 \mathrm{~m}$ are most frequent during El Niño late winter months. 
northern part of the study area but only 0.59 percent more frequent than average in the southern part.

Long-term trends of mean, maximum, and minimum $H_{\text {sig }}$ values, as well as monthly $H_{\text {sig }}$ exceedances ( $>4 \mathrm{~m}$ and $>6 \mathrm{~m}$ ), all increased over the study period. Monthly mean $H_{\text {sig }}$ values on average increased by $0.020 \mathrm{~m} / \mathrm{yr}$ in all parts of the study area (figs. 1, 7A). Long-term trends of $H_{\text {sig }}$ variation increased the most (by $0.010 \mathrm{~m} / \mathrm{yr}$ ) in the southern part of the study area and the least (by $0.006 \mathrm{~m} / \mathrm{yr}$ ) in the northern part (fig. $7 B$ ). In addition, long-term trends of maximum $H_{\text {sig }}$ values on average also increased over the study period, specifically in a north-to-south trend: from $0.057 \mathrm{~m} / \mathrm{yr}$ in the northern part of the study area, through $0.068 \mathrm{~m} / \mathrm{yr}$ in the central part, to $0.077 \mathrm{~m} / \mathrm{yr}$ in the southern part (fig. $7 C$ ). In contrast, long-term trends of minimum

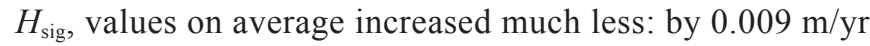
in the northern part of the study area and by only 0.002 $\mathrm{m} / \mathrm{yr}$ in the southern part (fig. $7 \mathrm{D}$ ). Long-term trends of monthly $H_{\text {sig }}$ values larger than $4 \mathrm{~m}$ on average increased

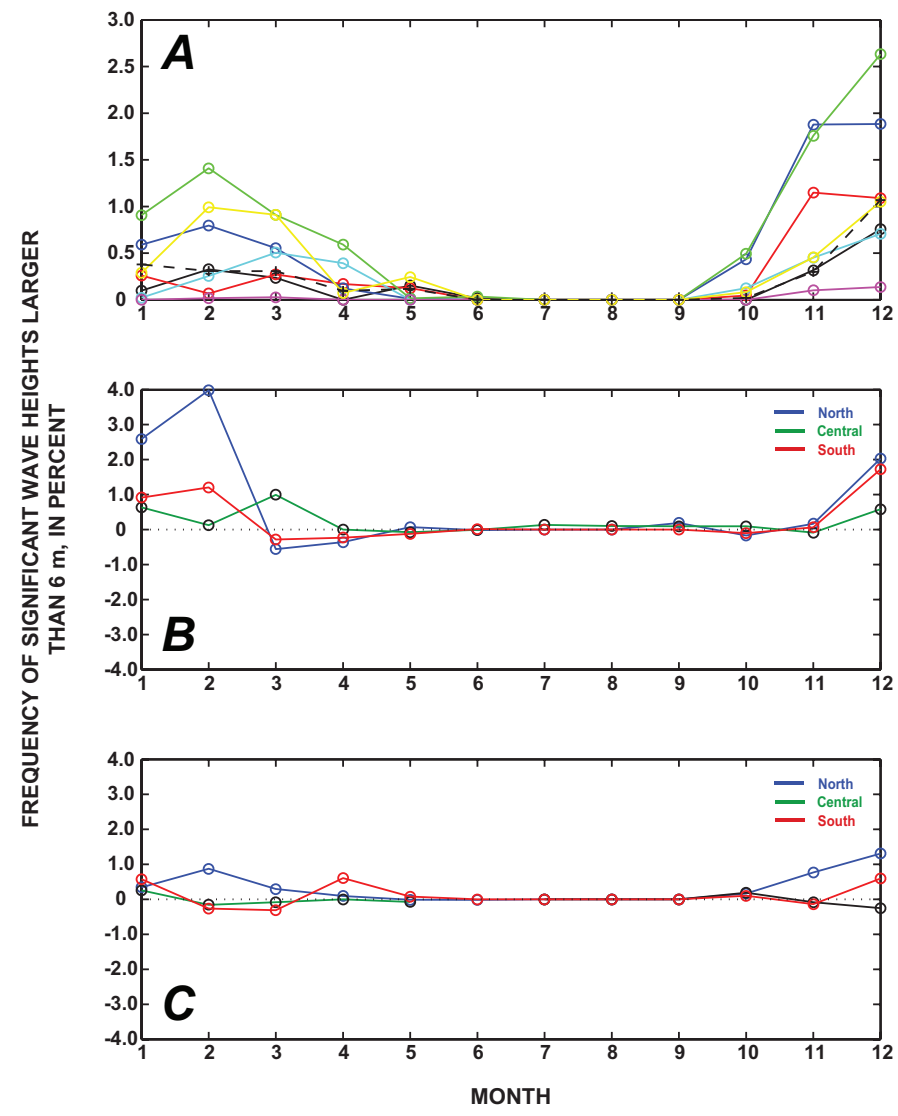

Figure 6. Monthly variation in significant wave heights $\left(H_{\text {sig }}\right)$ larger than $6 \mathrm{~m}$ during all months $(A)$, during El Niño months $(B)$, and during La Niña months $(C)$ throughout study area (fig. 1) over study period (1980-2002). Colored curves in figure $6 A$ correspond to individual buoys located in figure 1 . Note that $H_{\text {sig }}$ values larger than $6 \mathrm{~m}$ are consistently most frequent in northern part of study area (fig. 1). by $0.004 \mathrm{~m} / \mathrm{yr}$ at the north end of the study area and by $0.002 \mathrm{~m} / \mathrm{yr}$ at the south end (fig. $8 A$ ). Long-term trends of monthly $H_{\text {sig }}$ values larger than $6 \mathrm{~m}$ trends were not statistically significant (fig. $8 B$ ).

\section{Dominant Wave Period}

Mean $T_{\text {dom }}$ values range from 8.78 to $10.09 \mathrm{~s}$ during the summer and from 12.08 to $13.71 \mathrm{~s}$ during the winter (fig. $9 A$; see apps. $3,8-15)$. Mean $T_{\text {dom }}$ values typically peak in February: at $12.94 \mathrm{~s}$ in the northern part of the study area (fig. 1) and at $13.71 \mathrm{~s}$ in the southern part. Generally, mean $T_{\text {dom }}$ values are shorter in the summer and shortest in July and August: $8.78 \mathrm{~s}$ in the northern part of the study area and $9.44 \mathrm{~s}$ in the southern part. Annual mean $T_{\text {dom }}$ values on average are $0.60 \mathrm{~s}$ longer in the southern part of the study area than in the northern part.

Mean $T_{\text {dom }}$ values are typically 0.24 to $1.81 \mathrm{~s}$ longer during El Niño winter months than during normal winter months (fig. 9B). El Niño $T_{\text {dom }}$ values generally peak in January, 1 month earlier than during normal months, ranging from $0.96 \mathrm{~s}$ longer in the northern part of the study area (fig. 1) to $1.81 \mathrm{~s}$ longer in the southern part. Only in the central part of the study area are mean $T_{\text {dom }}$ values shorter than normal (by $0.15 \mathrm{~s}$ ) in February, possibly owing to the passage of storms through this part of the study area. Mean $T_{\text {dom }}$ values are longer than normal in the northern and southern parts of the study area during February (by 0.86 $\mathrm{s}$ and $0.07 \mathrm{~s}$, respectively). Mean $T_{\text {dom }}$ variation is greater during El Niño summer months than during El Niño winter months, ranging from $0.46 \mathrm{~s}$ shorter than average to $0.41 \mathrm{~s}$ longer than average. Mean $T_{\text {dom }}$ values in the southern part of the study area remain slightly longer than in the central or northern parts until September, when they are $0.30 \mathrm{~s}$ shorter than average in the northern part of the study area and $0.74 \mathrm{~s}$ shorter than average in the southern part.

During La Niña winter months, mean $T_{\text {dom }}$ values peak in November, ranging from $1.13 \mathrm{~s}$ longer in the northern part of the study area to $1.28 \mathrm{~s}$ longer than normal in the southern part (figs. 1, 9C). During La Niña months, mean $T_{\text {dom }}$ values are shortest in February, ranging from 0.41 to $0.60 \mathrm{~s}$ shorter than average throughout the study area. During La Niña summer months, mean $T_{\text {dom }}$ values are generally at or above average in the southern and central portions of the study area, and generally slightly below average in the northern part. During La Niña summer months, mean $T_{\text {dom }}$ values range from $0.30 \mathrm{~s}$ shorter than average in the northern part of the study area to $0.79 \mathrm{~s}$ longer than average in the southern part. In general, mean $T_{\text {dom }}$ variation is greatest in the southern part of the study area throughout the year during both El Niño and La Niña months.

Long-term trends of mean $T_{\text {dom }}$ variation on average increased over the study period (fig. 10A): from $0.035 \mathrm{~s} / \mathrm{yr}$ in the northern part of the study area to $0.045 \mathrm{~s} / \mathrm{yr}$ in the 

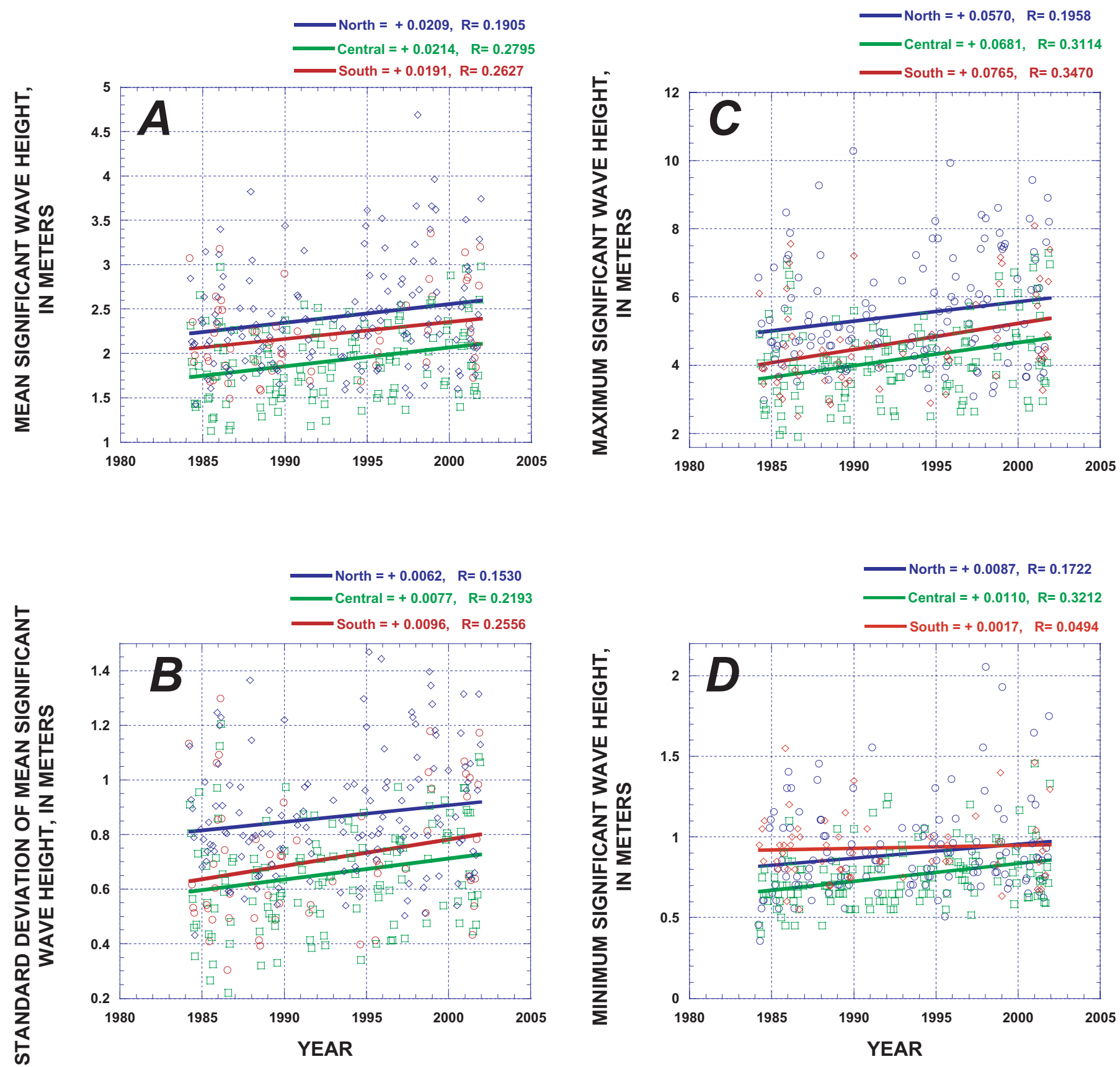

Figure 7. Long-term trends of mean significant wave height $\left(H_{\text {sig }}\right)$ throughout study area (fig. 1) over study period (1980-2002). $A$, Mean $H_{\text {sig }}$ value. $B$, Standard deviation of mean $H_{\text {sig }}$ value. $C$, Maximum $H_{\text {sig }}$ value. $D$, Minimum $H_{\text {sig }}$ value. Note that trendlines show increases in all parameters. 

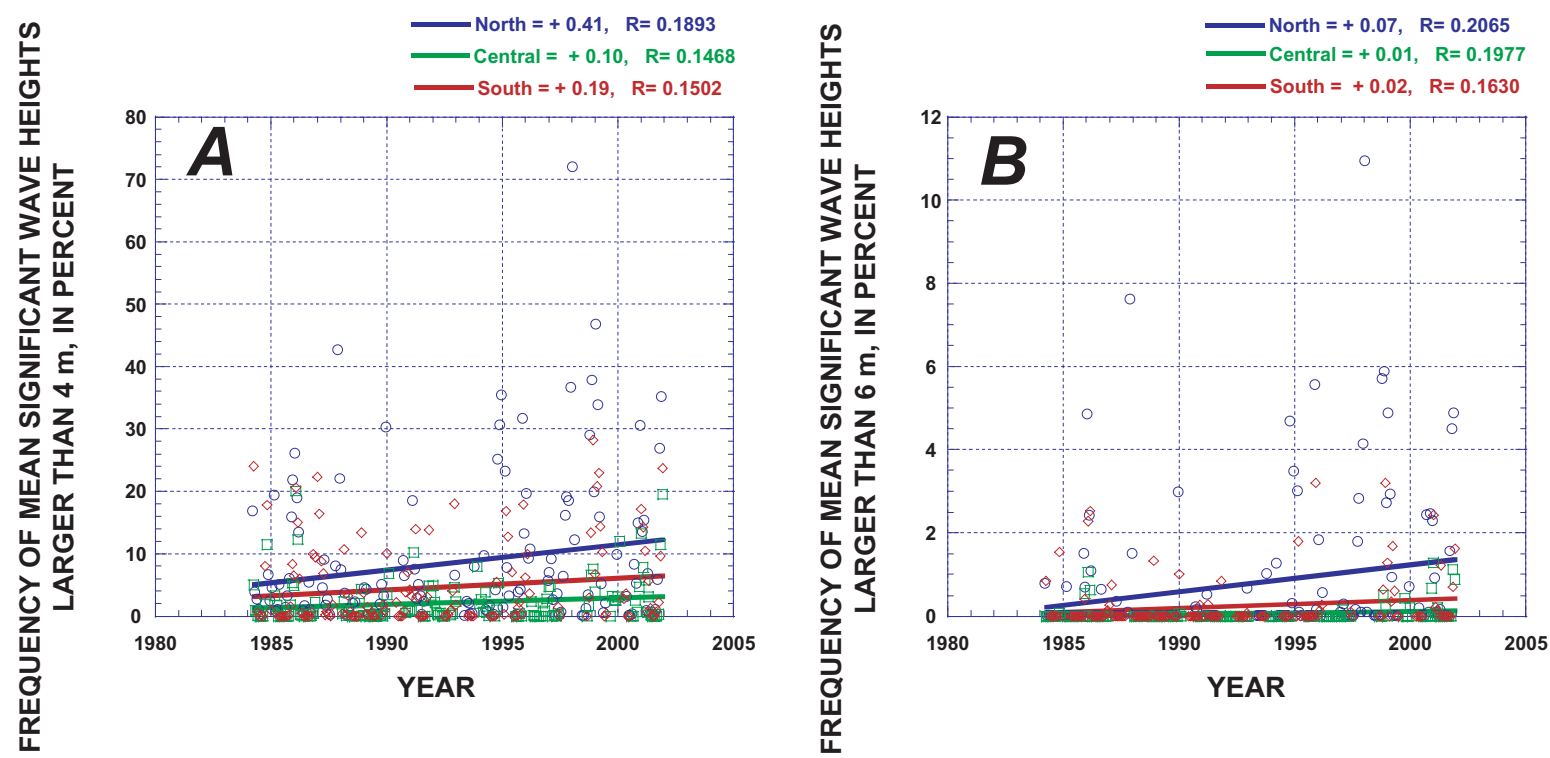

Figure 8. Long-term trends of exceedances of significant wave heights $\left(H_{\text {sig }}\right)$ larger than $4 \mathrm{~m}(A)$ and larger than $6 \mathrm{~m}(B)$ throughout study area (fig. 1) over study period (1980-2002). Note that trendlines show increases in both parameters.

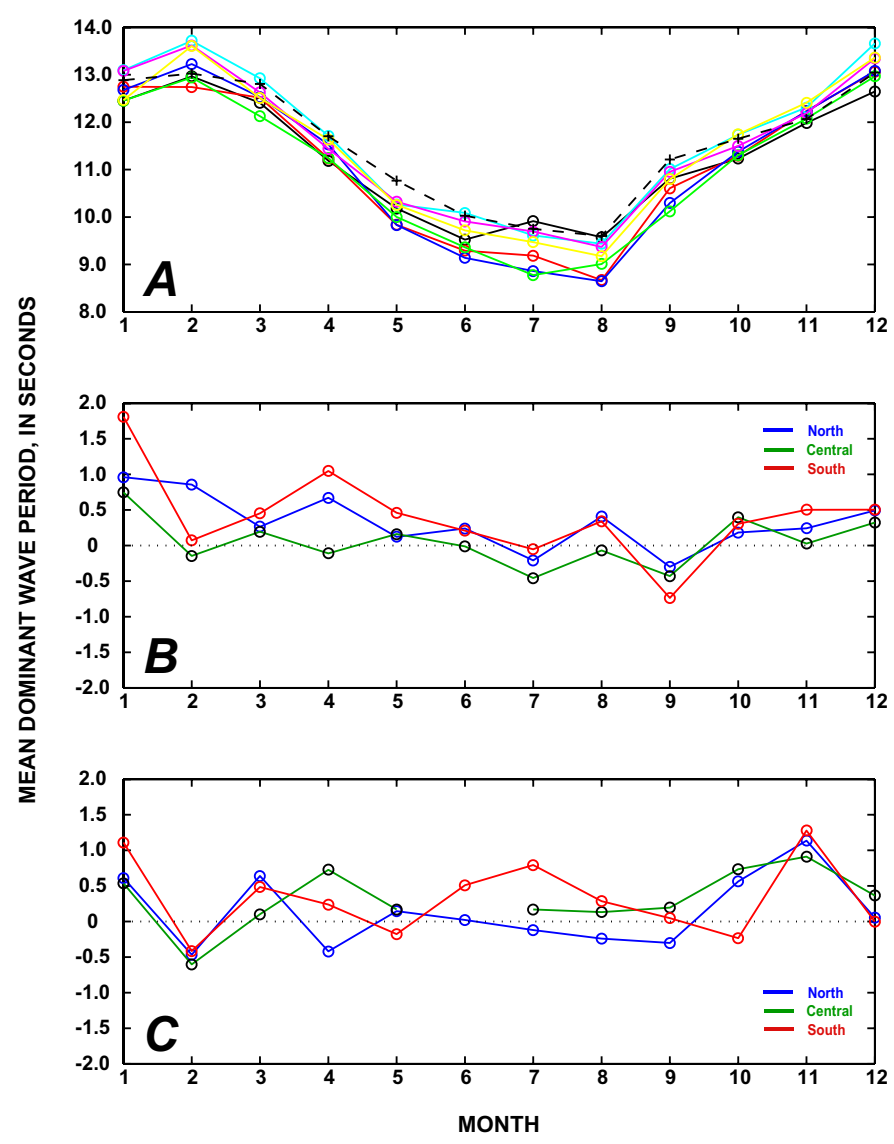

Figure 9. Monthly variation in mean dominant wave period $\left(T_{\text {dom }}\right)$ during all months $(A)$, during El Niño months $(B)$, and during La Niña months (C) throughout study area (fig. 1) over study period (1980-2002). Colored curves in figure $9 A$ correspond to individual buoys located in figure 1. Note that monthly mean $T_{\text {dom }}$ variation is greatest during El Niño late winter months and La Niña early winter months. southern part (figs. 1, 10A). In addition, the mean $T_{\text {dom }}$ standard deviation increased in all parts of the study area. Long-term trends of maximum $T_{\text {dom }}$ values increased in all parts of the study area: from $0.035 \mathrm{~s} / \mathrm{yr}$ in the southern part of the study area to $0.061 \mathrm{~s} / \mathrm{yr}$ in the northern part (fig. $10 C)$. Long-term trends of minimum $T_{\text {dom }}$ values increased in both the northern and southern parts of the study area (by 0.001 and $0.028 \mathrm{~s} / \mathrm{yr}$, respectively), whereas the variation in minimum $T_{\text {dom }}$ values for the central part was not statistically significant (fig. 10D).

\section{Sea-Level Barometric Pressure}

Mean $S L B_{\text {pres }}$ values range from 1017.52 to 1019.55 mbars during normal winter months and from 1014.26 to 1017.31 mbars during normal summer months (fig. 11A; see apps. 4, 8-15). Mean $S L B_{\text {pres }}$ north-to-south spatial variation is less in winter than in summer. For example, during normal winter months, mean $S L B_{\text {pres }}$ values on average are only 0.60 mbar higher in the northern part of the study area (fig. 1) than in the southern part. In contrast, during the summer months, mean $S L B_{\text {pres }}$ values on average are 2.64 mbars higher in the northern part of the study area than in the southern part. Mean $S L B_{\text {pres }}$ values generally peak in the winter and reach their lowest point in the late summer. During the winter months of December and January, mean $S L B_{\text {pres }}$ values are highest in the north-central part of the study area (Bodega buoy, sta. 46013, fig. 1), reaching 1019.95 mbars. Conversely, mean $S L B_{\text {pres }}$ values are lowest from June to August, dropping to 1014.44 mbars in the southern part of the study area.

Mean $S L B_{\text {pres }}$ values are generally 0.34 to 7.44 mbars lower during El Niño winter months than during normal winter months (fig. 11B). Mean $S L B_{\text {pres }}$ variation is greatest during 

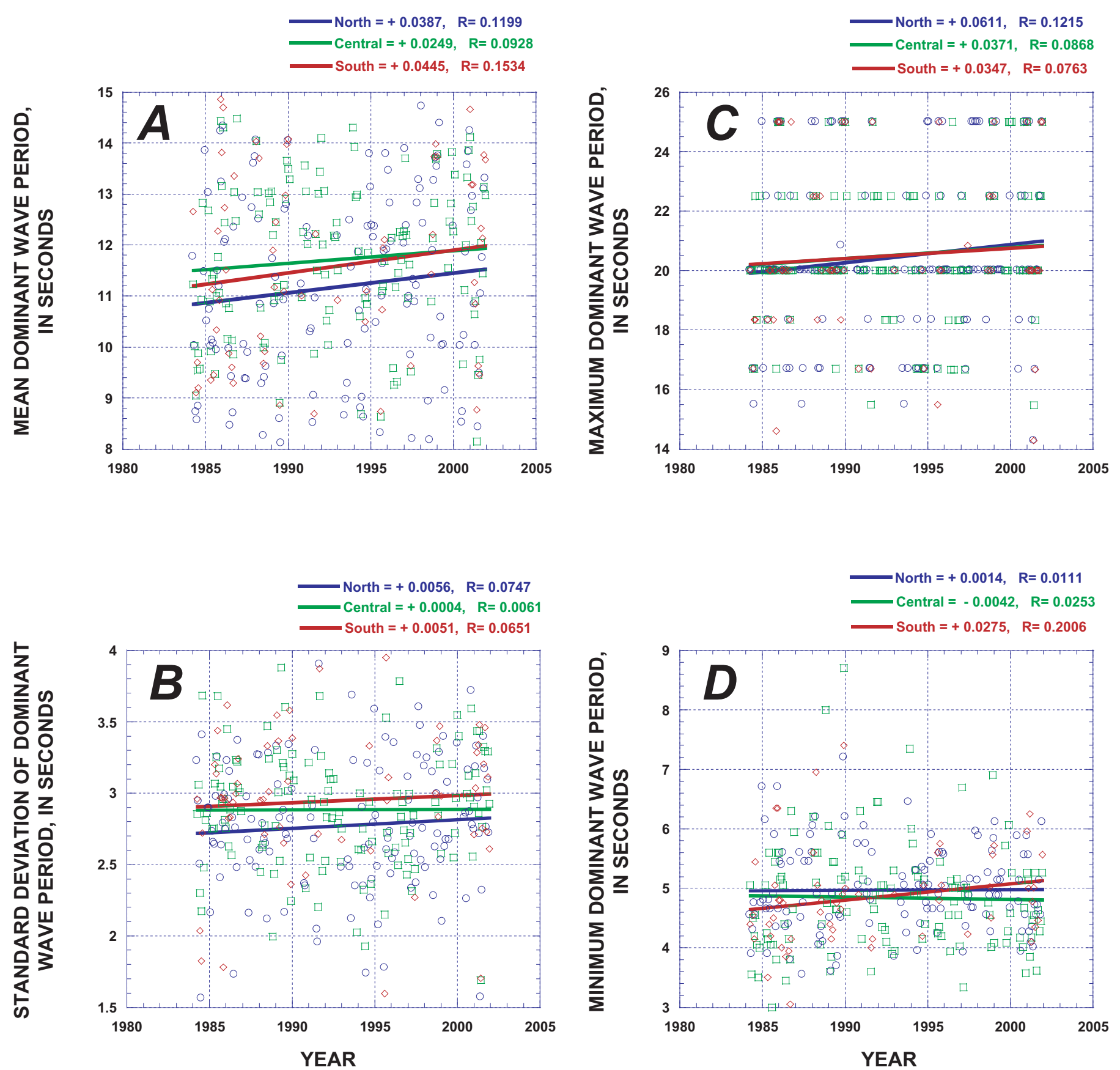

Figure 10. Long-term trends of mean dominant wave period ( $\left.T_{\text {dom }}\right)$ throughout study area (fig. 1) over study period (1980-2002). $A$, Mean $T_{\text {dom }}$ value. $B$, Standard deviation of mean $T_{\text {dom }}$ value. $C$, Maximum $T_{\text {dom }}$ value. $D$, Minimum $T_{\text {dom }}$ value. Note that trendlines show increasing spatial variation in mean, standard deviation of mean, and minimum $T_{\text {dom }}$ values. 
the El Niño month of February, ranging from 1.81 mbars lower than average in the southern part of the study area (fig. 1) to 7.44 mbars lower than average in the northern part. Mean $S L B_{\text {pres }}$ values are consistently lower than average during El Niño winter months but typically slightly higher than average during La Niña winter months, when mean $S L B_{\text {pres }}$ values peak in December (fig. 11C). During La Niña winter months, mean $S L B_{\text {pres }}$ values range from 1.45 mbars higher than average in the southern part of the study area to 2.48 mbars greater than average in the northern part.

Mean $S L B_{\text {pres }}$ variation is generally less during the summer than during the winter for both El Niño and La Niña events. During El Niño summer months from May to July, mean $S L B_{\text {pres }}$ values are 0.15 to 0.87 mbar below average in the northern part of the study area and 0.32 to 0.66 mbar below average in the southern part (figs. 1, 11B). In

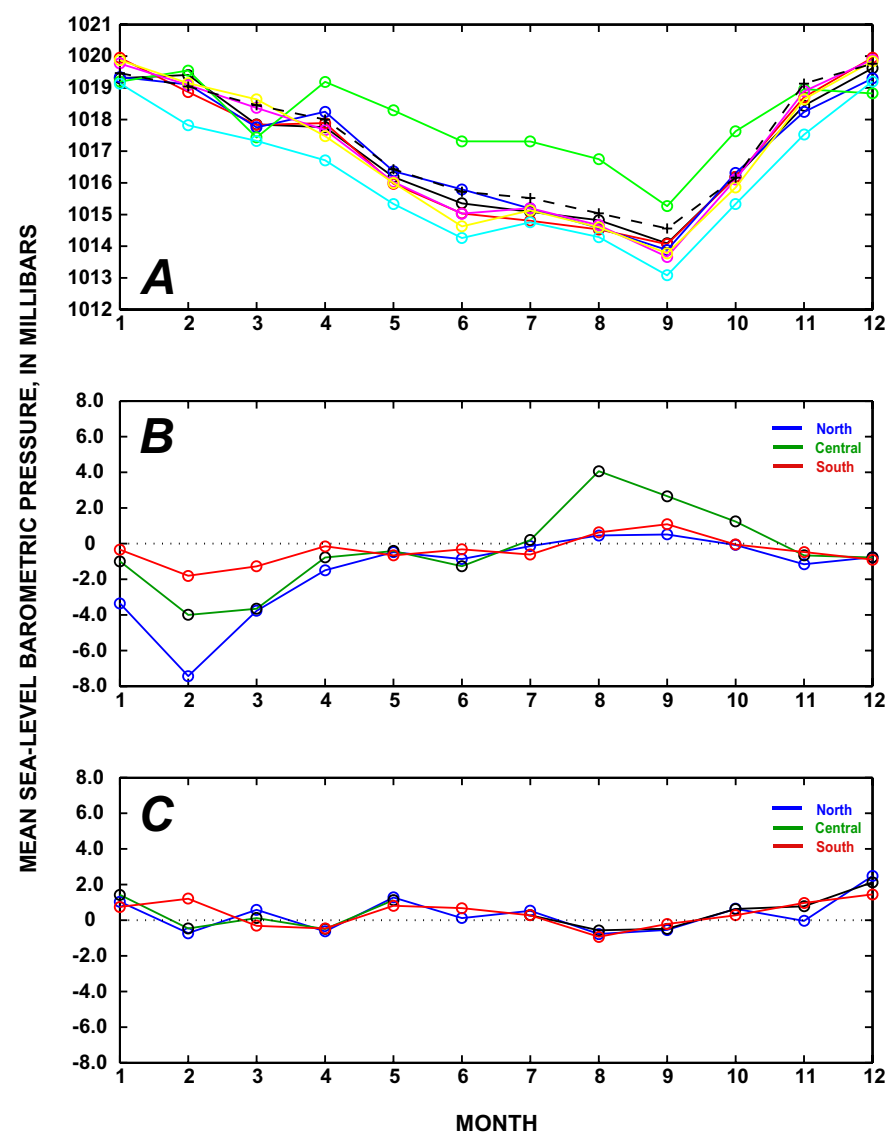

Figure 11. Monthly variation in mean sea-level barometric pressure $\left(S L B_{\text {pres }}\right)$ during all months $(A)$, during El Niño months $(B)$, and during La Niña months $(C)$ throughout study area (fig. 1) over study period (1980-2002). Colored curves in figure $11 A$ correspond to individual buoys located in figure 1 . Note that monthly mean $S L B_{\text {pres }}$ values are lower during El Niño late winter months than during La Niña winter months. the central part of the study area, mean $S L B_{\text {pres }}$ variation is greatest during El Niño summer months, ranging from 1.27 mbars below average in June to 4.06 mbars above average in August. In contrast, mean $S L B_{\text {pres }}$ values during La Niña summer months range downward from 1.27 mbars above normal in May to only 0.27 mbar above normal in July (fig. $11 C$ ). During the La Niña month of August, mean $S L B_{\text {pres }}$ values in the southern part of the study area decrease the most - to 0.93 mbar below average.

Over the study period, monthly $S L B_{\text {pres }}$ values lower than 1000 mbars are typically more frequent from November to March (fig. 12A). Conversely, almost no monthly $S L B_{\text {pres }}$ values less than 1000 mbars occur during the rest of the year. In December, as many as 3.27 percent of total monthly $S L B_{\text {pres }}$ observations are lower than 1000 mbars at the north end of the study area (fig. 1) but almost none in the southern part, where they are more frequent in the late
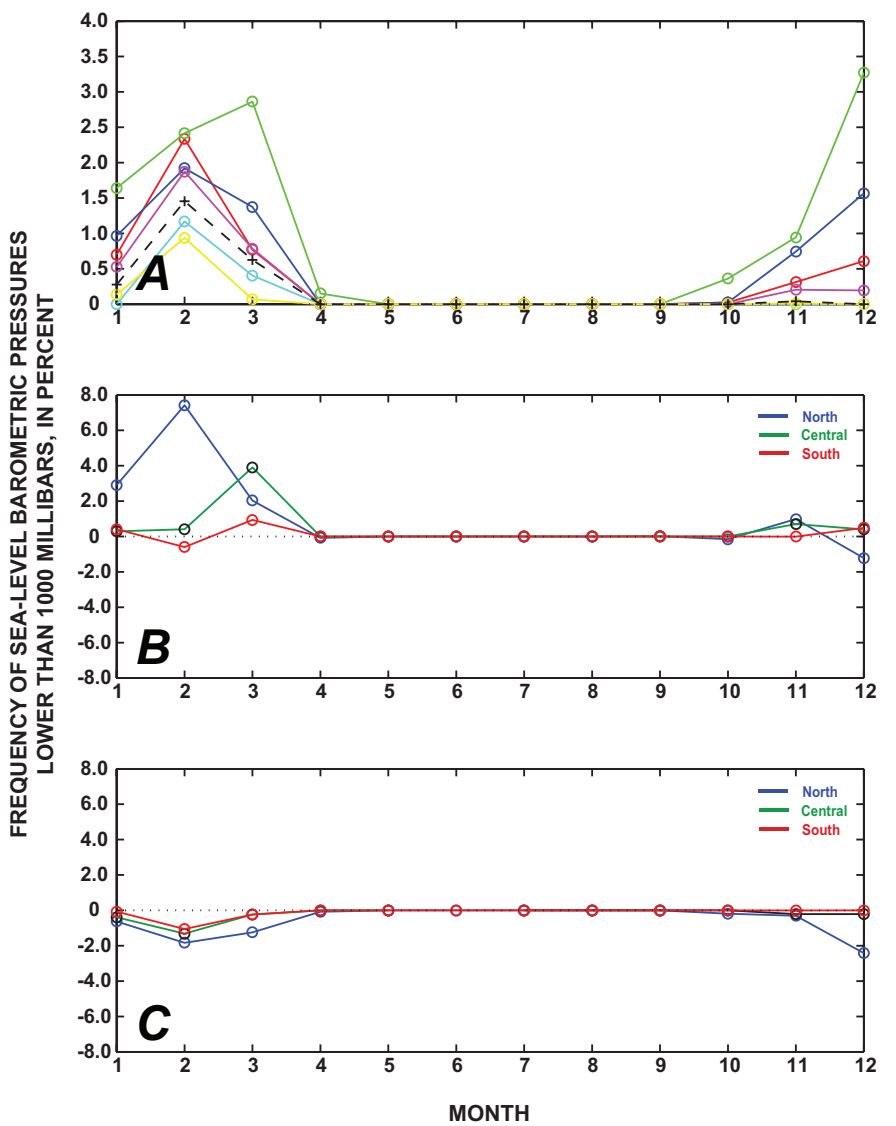

Figure 12. Monthly variation in sea-level barometric pressures $\left(S L B_{\text {pres }}\right)$ lower than 1000 mbars during all months $(A)$, during El Niño months $(B)$, and during La Niña months $(C)$ throughout study area (fig. 1) over study period (1980-2002). Colored curves in figure 12A correspond to individual buoys located in figure 1. Note that although $S L B_{\text {pres }}$ values lower than 1000 mbars are frequent during normal winter months, they are most frequent during El Niño winter months, particularly January through March, when storms are most common. 
winter (February), when as many as 1.17 percent of total monthly $S L B_{\text {pres }}$ observations are lower than 1000 mbars.

Monthly $S L B_{\text {pres }}$ values lower than 1000 mbars are 0.30 to 7.42 percent more frequent during El Niño winter months than during normal winter months (fig. 12B). In the northern part of the study area (fig. 1), they are most frequent in February, when they are 7.42 percent more frequent than average. In the central and southern parts of the study area, they are most frequent in March, when they are 3.91 percent more frequent than average in the central part and 0.94 percent more frequent than average in the southern part. Conversely, they are even less frequent during La Niña winter months than during normal winter months. In the northern part of the study area, they are least frequent in December, when they are as much as 2.42 percent less frequent than average (fig. 12C).

Over the study period, monthly $S L B_{\text {pres }}$ values lower than 990 mbars are rare (fig. 13A). During normal months, they are most frequent in the northern part of the study area (fig. 1) but so infrequent as not to be statistically significant in the southern part. They are most frequent March, when they are typically 0.50 percent more frequent than average, and in December, when they are 0.35 percent more frequent than average. During El Niño winter months, monthly $S L B$ pres values lower than 990 mbars are also most frequent in the northern part of the study area from February to March (fig. 13B), when they are as much as 1.54 percent more frequent than in normal winter months. Conversely, during La Niña winter months, monthly $S L B_{\text {pres }}$ values lower than 990 mbars are 0.17 and 0.31 percent less frequent than average in February and March, respectively, in the northern part of the study area (fig. 13C).

Although interannual events have varying effects on mean $S L B_{\text {pres }}$ values, long-term trends of mean $S L B_{\text {pres }}$ values decreased over the study period, mainly in the northern and central parts of the study area (0.044 and 0.046 $\mathrm{mbar} / \mathrm{yr}$, respectively), while the long-term trend in the southern part was not statistically significant (figs. 1, 14A). Long-term trends of $S L B_{\text {pres }}$ variation in the southern part of the study area were not statistically significant (figs. $14 B$, $14 C$ ). Long-term trends of minimum mean $S L B_{\text {pres }}$ values decreased in the northern and southern parts of the study area-almost twice as fast in the northern part as in the southern part ( 0.142 and $0.055 \mathrm{mbar} / \mathrm{yr}$, respectively, fig. $14 D)$.

Long-term trends of the frequency of monthly $S L B_{\text {pres }}$ values lower than 1000 mbars increased by 0.03 percent/ $\mathrm{yr}$ in the northern part of the study area; the long-term trend in the central and southern parts was not statistically significant (figs. 1, 15).

\section{Sea-Surface Water Temperature}

The distribution of monthly mean $W_{\text {temp }}$ values in the study area (fig. 1) is plotted in figure $16 \mathrm{~A}$ (see apps. 5,
$8-15)$. The coolest seasonal mean $W_{\text {temp }}$ values are generally during the spring and early summer months, ranging from 10.78 to $11.17^{\circ} \mathrm{C}$ in the northern part of the study area and from 12.04 to $13.45^{\circ} \mathrm{C}$ in the southern part. The coolest mean $W_{\text {temp }}$ values for all parts of the study area are at Bodega Bay, one of the north-central buoy locations. Between the spring and early summer, mean $W_{\text {temp }}$ values at Bodega Bay drop from $11.82^{\circ} \mathrm{C}$ (March) to $9.95^{\circ} \mathrm{C}$ (June), likely owing to southward advection of the water upwelled just south of Point Arena by typical winds out of the northwest. Monthly mean $W_{\text {temp }}$ values are warmest in August and September, ranging from $12.74^{\circ} \mathrm{C}$ in the northern part of the study area to $15.95^{\circ} \mathrm{C}$ in the southern part. Winter mean $W_{\text {temp }}$ values from November to February are typically the coolest of the year, averaging $11.45^{\circ} \mathrm{C}$ in the northern part of the study area and $14.18^{\circ} \mathrm{C}$ in the southern part, resulting in a spatial variation of approximately $2.73^{\circ} \mathrm{C}$

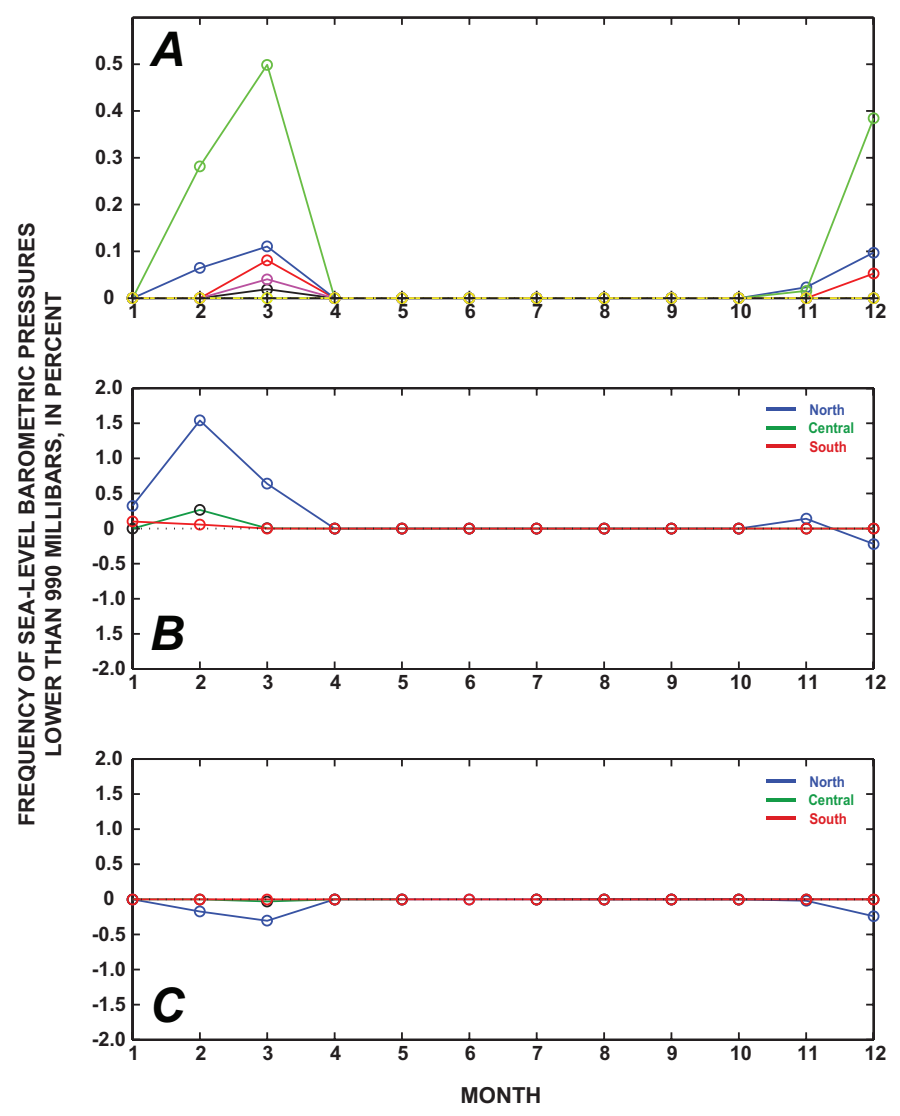

Figure 13. Monthly variation in sea-level barometric pressures (SLBpres) lower than 990 mbars during all months $(A)$, during El Niño months $(B)$, and during La Niña months $(C)$ throughout study area (fig. 1) over study period (1980-2002). Colored curves in figure 13A correspond to individual buoys located in figure 1. Note that although $S L B_{\text {pres }}$ values lower than 990 mbars are frequent during normal winter months, they are most frequent during El Niño winter months, particularly January through March, when storms are most common. 

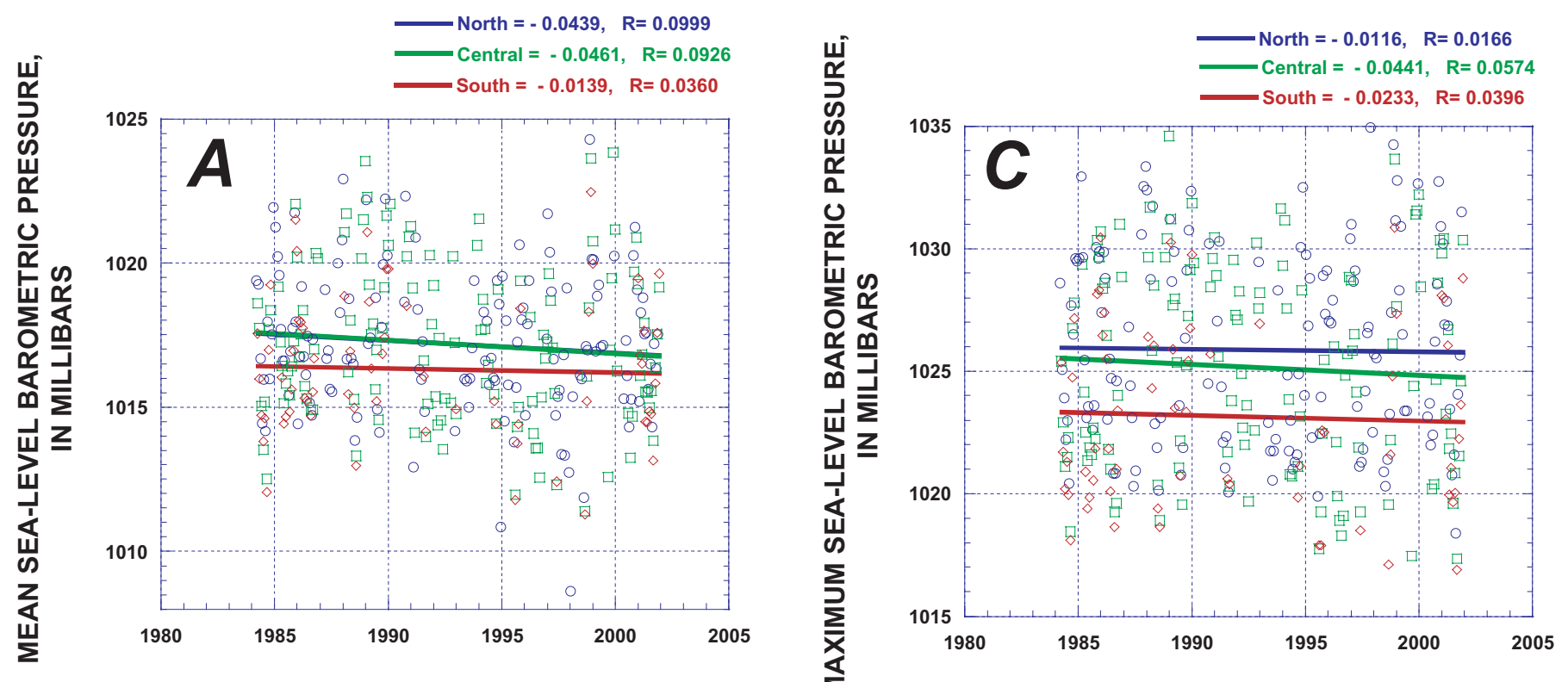

U

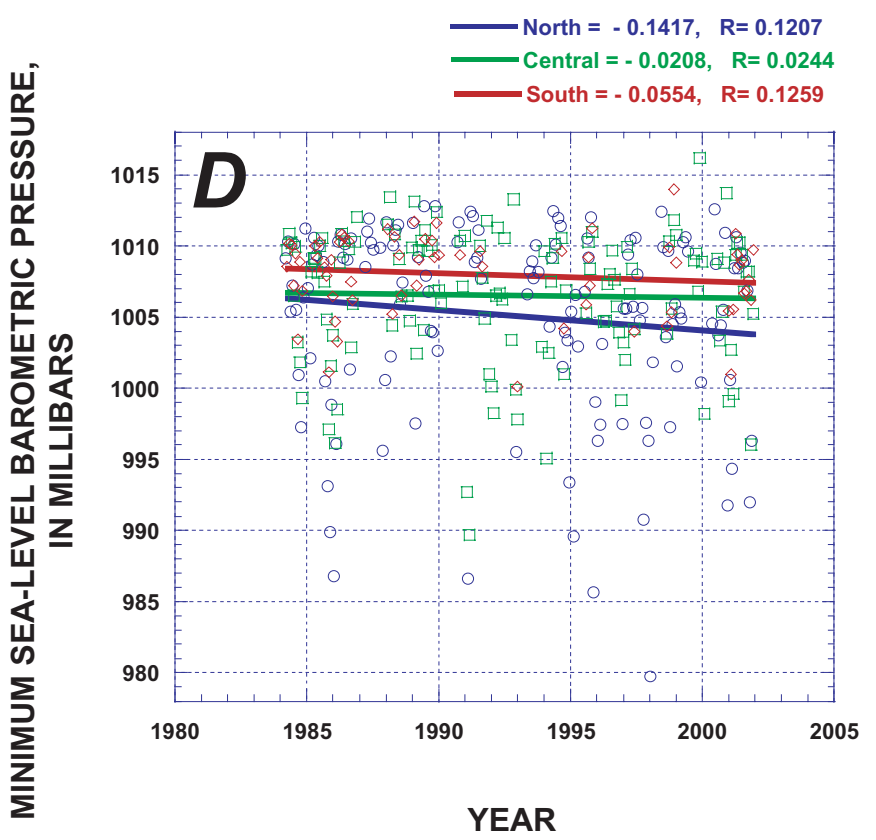

Figure 14. Long-term trends of mean sea-level barometric pressure ( $\left.S L B_{\text {pres }}\right)$ throughout study area (fig. 1) over study period (1980-2002). $A$, Mean $S L B_{\text {pres }}$ value. $B$, Standard deviation of mean $S L B_{\text {pres }}$ value. $C$, Maximum $S L B_{\text {pres }}$ value. $D$, Minimum $S L B_{\text {pres }}$ value. Note that trendlines show decreases in mean, maximum, and minimum $S L B_{\text {pres }}$ values and increasing $S L B_{\text {pres }}$ variation. 
between the northern (cooler) and southern (warmer) parts of the study area.

During El Niño months, monthly mean $W_{\text {temp }}$ values are warmer than normal year round (fig. $16 B$ ). In winter, monthly mean $W_{\text {temp }}$ values are $0.17-1.46^{\circ} \mathrm{C}$ warmer than average, and in spring and early summer $0.37-1.46^{\circ} \mathrm{C}$ warmer than average. Mean $W_{\text {temp }}$ variation in the southern part of the study area (fig. 1) is greatest in September, when mean $W_{\text {temp }}$ values are $1.19^{\circ} \mathrm{C}$ warmer than average, but in the northern and central parts is greatest from February to May, when mean $W_{\text {temp }}$ values are $1.72^{\circ} \mathrm{C}$ warmer than average in the northern part and $1.75^{\circ} \mathrm{C}$ warmer than average the central part.

In contrast to the warmer-than-average mean $W_{\text {temp }}$ values during El Niño winter months, mean $W_{\text {temp }}$ values during La Niña winter months are cooler than average. Mean $W_{\text {temp }}$ values are $0.21-0.64^{\circ} \mathrm{C}$ cooler than average in the northern part of the study area (fig. 1) and $0.49-1.20^{\circ} \mathrm{C}$ cooler than average in the southern part (fig. 16C). In addition, mean $W_{\text {temp }}$ values are coolest during the La Niña month of March, when they are $0.97-1.29^{\circ} \mathrm{C}$ cooler than average.

Long-term trends of mean $W_{\text {temp }}$ values on average increased $0.03^{\circ} \mathrm{C} / \mathrm{yr}$ in the northern part of the study area (fig. 1) but on average decreased $0.03^{\circ} \mathrm{C} / \mathrm{yr}$ in the southern part (fig. 17A). Long-term trends of the standard deviation of mean $W_{\text {temp }}$, values indicate a decrease in the mean $W_{\text {temp }}$ variation in the central and southern parts of the study area over the study period; the change in mean $W_{\text {temp }}$ varia-

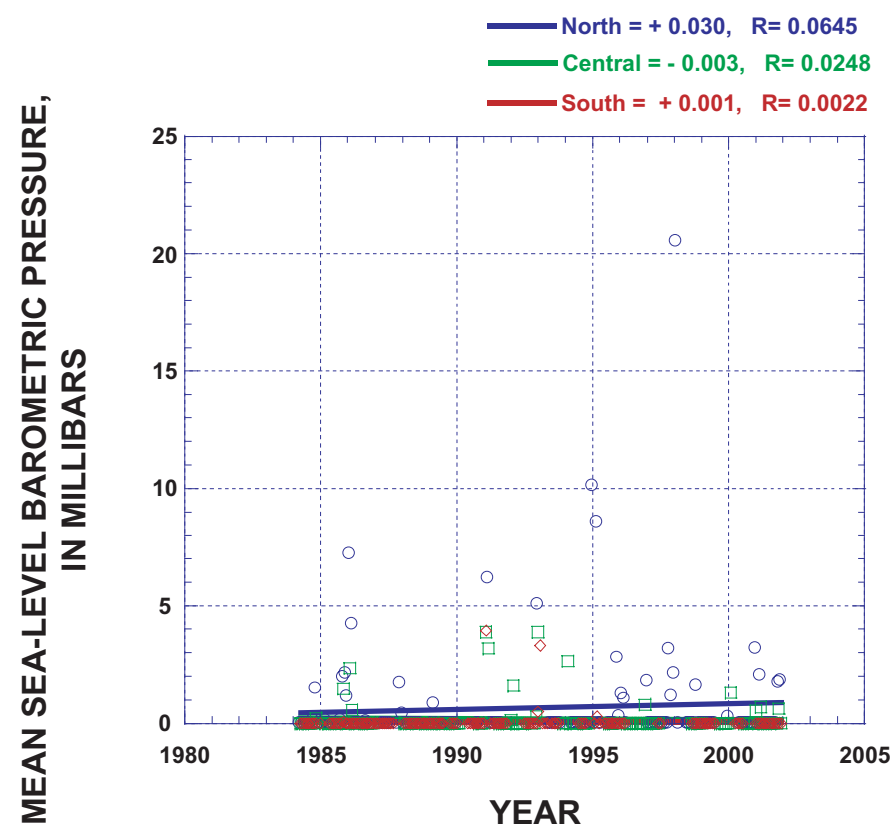

Figure 15. Long-term trends of sea-level barometric pressures ( $S L B_{\text {pres }}$ ) lower than 1000 mbars throughout study area (fig. 1) over study period (1980-2002). Trends are not statistically significant. tion in the northern part was not statistically significant (fig. 17B). Long-term trends of maximum $W_{\text {temp }}$ values also were not statistically significant (fig. 17C). In addition, long-term trends of minimum $W_{\text {temp }}$ values on average increased by $0.03^{\circ} \mathrm{C} / \mathrm{yr}$ in the northern part of the study area and on average decreased by $0.02^{\circ} \mathrm{C} / \mathrm{yr}$ in the southern part; the long-term trend in the central part was not statistically significant (fig. 17D).

\section{Windspeed}

Unlike most of the other parameters, the $W N D_{\text {spd }}$ value does not show any well-defined north-to-south trend, although the two most southerly stations generally recorded the highest $W N D_{\text {spd }}$ values (fig. 18A; see app. 6). Throughout the year, monthly mean $W N D_{\text {spd }}$ values are generally highest during the late spring and early summer (March-June) and lowest during the fall and early winter
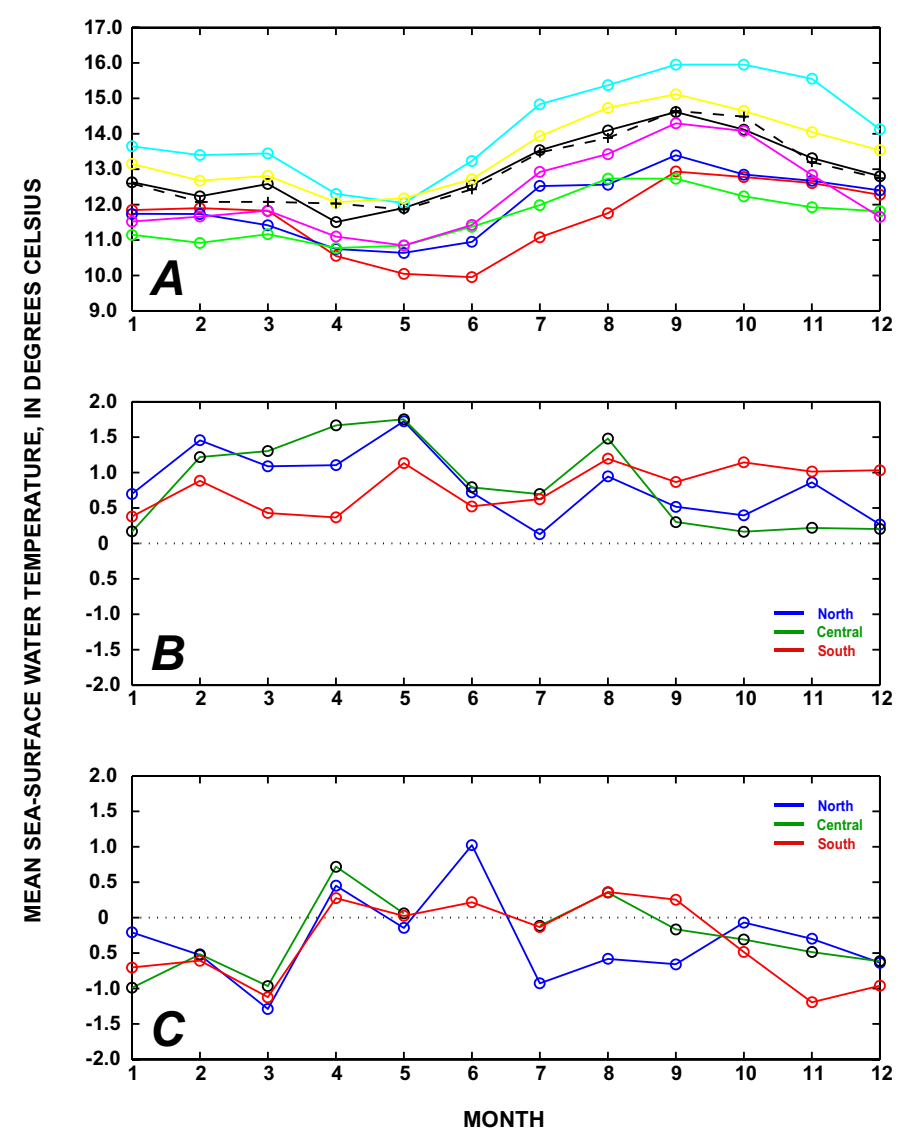

Figure 16. Monthly variation in mean sea-surface water temperature $\left(W_{\text {temp }}\right)$ during all months $(A)$, during El Niño months $(B)$, and during La Niña months $(C)$ throughout study area (fig. 1) over study period (1980-2002). Colored curves in figure $16 \mathrm{~A}$ correspond to individual buoys located in figure 1 . Note mean $W_{\text {temp }}$ values are warmer than normal year round during El Niño months and cooler than normal during La Niña winter months. 

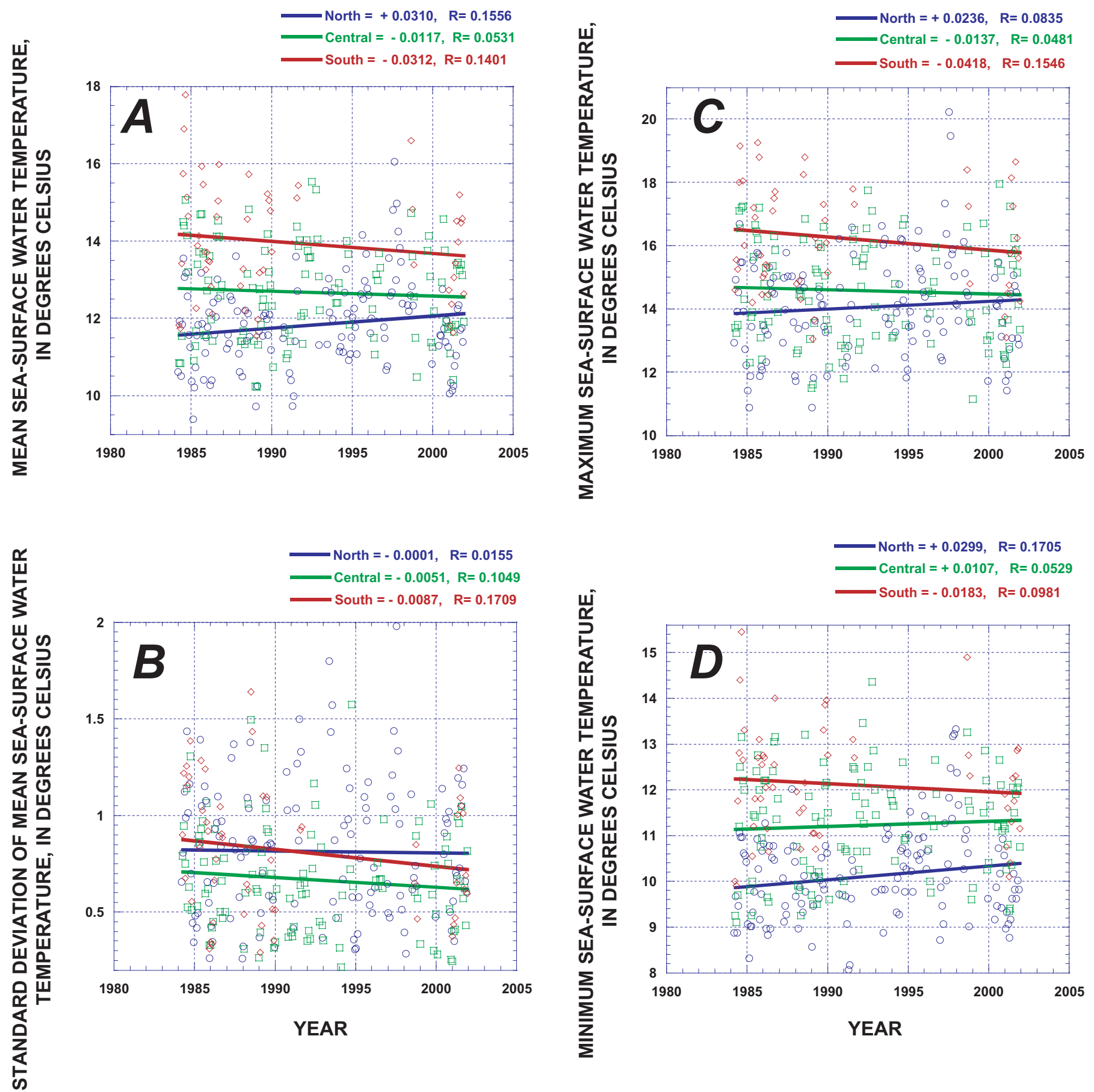

Figure 17. Long-term trends of mean sea-surface water temperature $\left(W_{\text {temp }}\right)$ throughout study area (fig. 1) over study period (1980-2002). $A$, Mean $W_{\text {temp }}$ value. $B$, Standard deviation of mean $W_{\text {temp }}$ value. $C$, Maximum $W_{\text {temp }}$ value. $D$, Minimum $W_{\text {temp }}$ value. Note that although trendlines vary between parts of study area, overall north-to-south spatial variation decreases. 
(September-December). The greatest longshore variation in mean monthly $W N D_{\text {spd }}$ values $(3.83 \mathrm{~m} / \mathrm{s})$ occurs during August, and the least $(0.77 \mathrm{~m} / \mathrm{s})$ during February.

During El Niño events, monthly mean $W N D_{\text {spd }}$ values on average are higher in the northern part of the study area and lower in the central and southern parts (fig. 1); during La Niña events, no overall general north-to-south trends in monthly mean $W N D_{\text {spd }}$ values are evident (figs. 18B, 18C). The month in which monthly mean $W N D_{\text {spd }}$ values increase the most varies throughout the study area. In the northern part, they increase the most $(1.92 \mathrm{~m} / \mathrm{s})$ during El Niño events in February; however, in the central and southern parts they increase the most during La Niña events, specifically during March $(1.09 \mathrm{~m} / \mathrm{s})$ and May $(1.11 \mathrm{~m} / \mathrm{s})$, respectively.

Long-term trends of mean $W N D_{\text {spd }}$ values increased over the north half of the study area (fig. 1): by $0.034 \mathrm{~m} / \mathrm{s} / \mathrm{yr}$ in the northern part and by $0.027 \mathrm{~m} / \mathrm{s} / \mathrm{yr}$ in the central part (fig. 19); the long-term trend in the southern part was not statistically

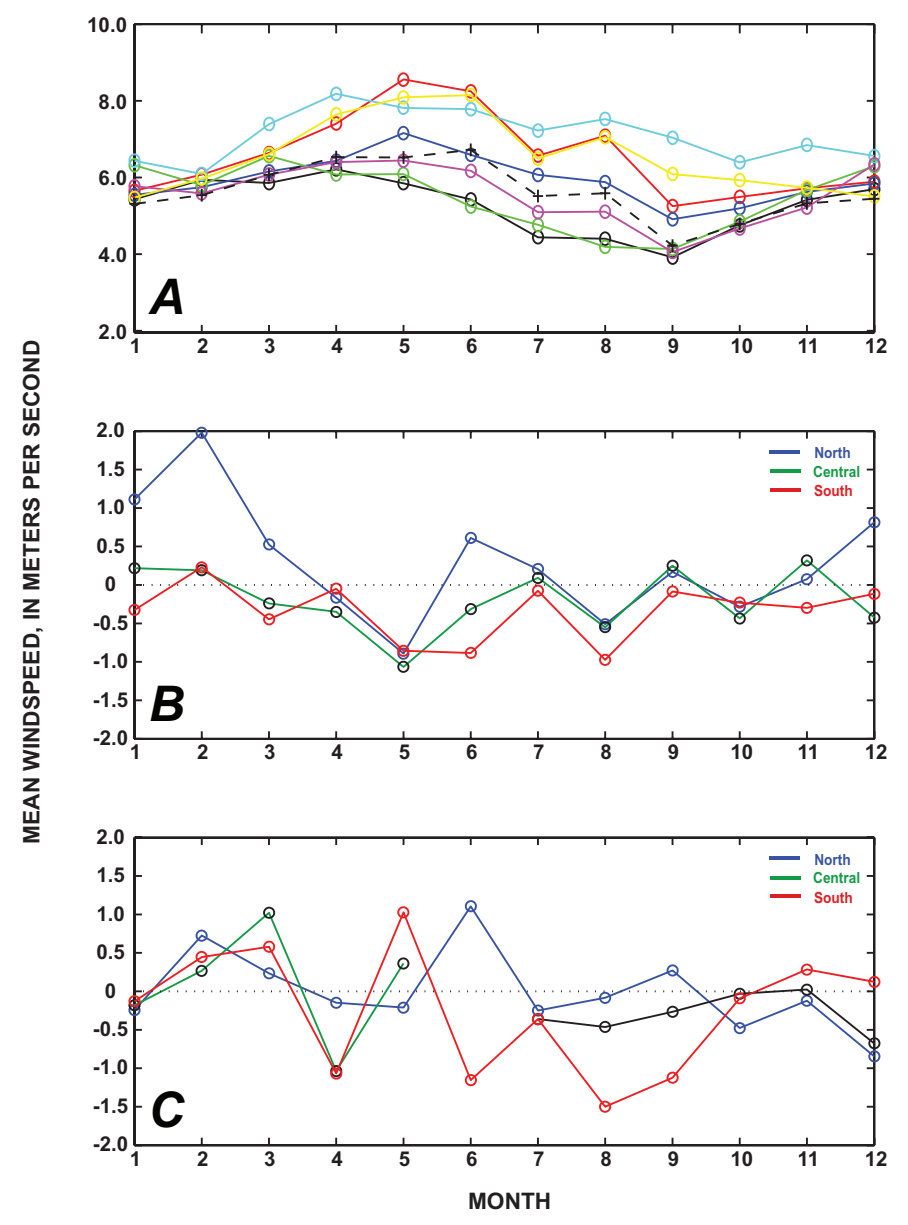

Figure 18. Monthly variation in mean windspeed $\left(W N D_{\text {spd }}\right)$ during all months $(A)$, during El Niño months $(B)$, and during La Niña months $(C)$ throughout study area (fig. 1) over study period (1980-2002). Colored curves in figure $18 A$ correspond to individual buoys located in figure 1. Note that mean $W N D_{\text {spd }}$ values are greater than normal during El Niño winter months and less than normal during La Niña winter months.

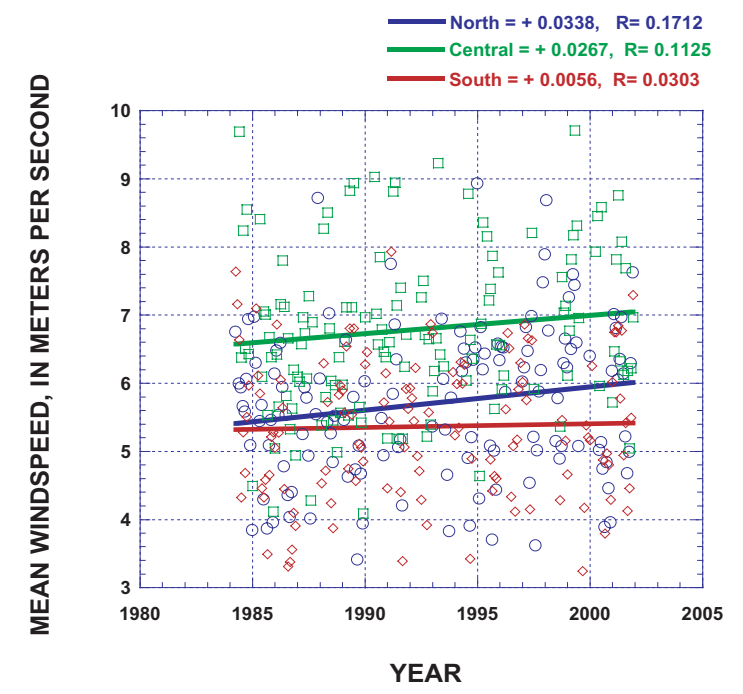

Figure 19. Long-term trends of mean wind speed $\left(W N D_{\text {spd }}\right)$ throughout study area (fig. 1) over study period (1980-2002). Note that trendlines show increases in northern and central parts of study area, suggesting increasing storm tracks through northern California.
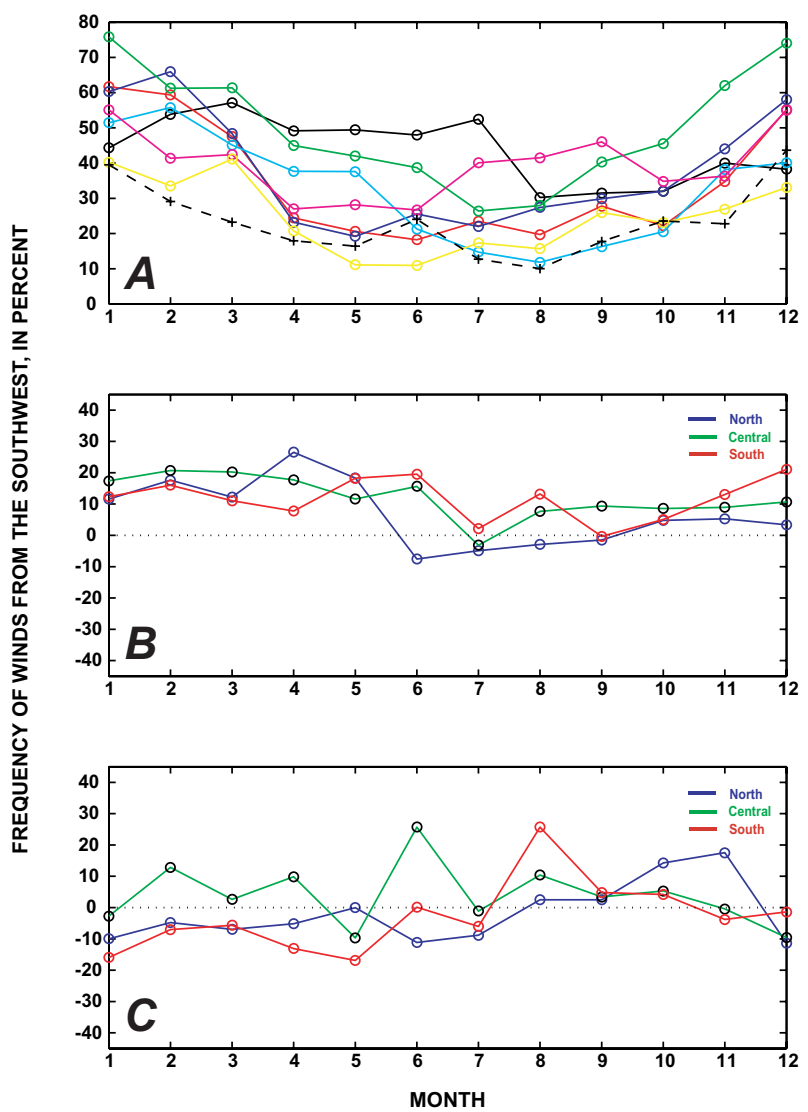

Figure 20. Monthly variation in frequency of winds from the southwest $\left(W N D_{\text {wsw }}\right)$ during all months $(A)$, during El Niño months $(B)$, and during La Niña months $(C)$ throughout study area (fig. 1) over study period (1980-2002). Colored curves in figure $20 A$ correspond to individual buoys located in figure 1. Note that $W N D_{\text {wsw }}$ values are higher than normal during El Niño months and lower than normal during La Niña months. 
significant. As these long-term trends continued over the study period, the north-to-south spatial gradient of mean $W N D_{\text {spd }}$ values increased.

\section{Frequency of Winds from the Southwest}

Throughout the year, monthly $W N D_{\text {wsw }}$ values are highest in the winter and lowest in the summer months (fig. $20 A$; see apps. 7-15). Monthly $W N D_{\text {wsw }}$ values are highest between November and February, ranging from 61.26 to 75.80 percent in the northern part of the study area (fig. 1) and from 38.17 to 55.76 percent in the southern part. During these winter months, the north-to-south spatial gradient of monthly $W N D_{\text {wsw }}$ values is greatest in December-33.99 percent greater in the northern part of the study area than in the southern part-but least in February - only 5.50 percent greater in the northern part. Monthly $W N D_{\text {wsw }}$ values are much lower in the spring and summer months than in the winter: 38.71 to 61.36 percent of monthly $W N D_{\text {wsw }}$ values in the northern part of the study area and 21.30 to 45.14 percent of monthly $W N D_{\text {wsw }}$ values in the southern part.

Monthly $W N D_{\text {wsw }}$ values are highest during El Niño winter months (fig. 20B). The month in which they are highest varies throughout the study area (fig. 1): in the southern part in early winter (December), when they are as much as 21.08 percent higher than average; in the central

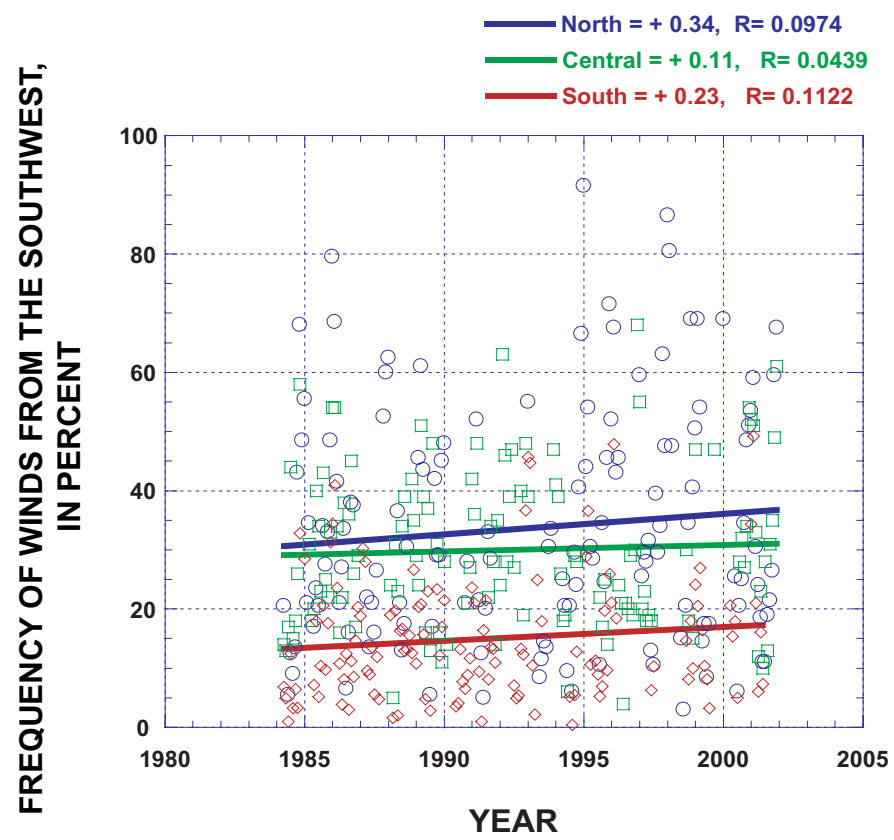

Figure 21. Long-term trends in frequency of winds from the southwest $\left(W N D_{\text {wsw }}\right)$ throughout study area (fig. 1) over study period (1980-2002). Note that trendlines show greatest increase in northern part of study area, suggesting increasing storm tracks through northern California. part during late El Niño winters (February), when they are as much as 20.25 percent higher than average; and in the northern part in April, when they are 26.50 percent higher than average.

In contrast, monthly $W N D_{\text {wsw }}$ values are typically, but not always, lower than average during La Niña winter months (fig. 20C). For example, in November, they are only 3.78 percent lower than average in the southern part of the study area (fig. 1) but 17.55 percent lower than average in the northern part. In January to March, they are 4.79 to 15.93 percent lower than average in the northern and southern parts of the study area and as much as 12.84 percent higher than average in the central part.

Long-term trends of monthly $W N D_{\text {wsw }}$ values on average increased over the study period: by $0.34 \mathrm{percent} / \mathrm{yr}$ in the northern part of the study area (fig. 1) and by 0.23 percent/yr in the southern part; the long-term trend in the central part was not statistically significant (fig. 21). As these trends continued over the study period, the north-to-south spatial gradient of monthly $W N D_{\text {wsw }}$ values increased.

\section{Directional Variations in Significant Wave Height, Dominant Wave Period, and Windspeed}

As stated above, only the Monterey Bay buoy (sta. 46042 , fig. 1) has the capability to measure $W V_{\text {dir }}$, which it gained only in 1993. Thus, to investigate the relations between directional variations in $H_{\text {sig }}, T_{\text {dom }}$, and $W N D_{\text {spd }}$, these analyses are limited to the 10 years of concurrent hourly (not monthly mean) $H_{\text {sig }}, T_{\text {dom }}$, and $W N D_{\text {spd }}$ data from 1993 to 2002. The hourly variation in $H_{\text {sig }}$ as a function of $W V_{\text {dir }}$ throughout the year is plotted in figure 22. Hourly $H_{\text {sig }}$ values are higher, and their variation is greater, in the winter months than in the summer, when $H_{\text {sig values are }}$ smaller and $W V_{\text {dir }}$ is primarily out of the northwest or south and the southwest. The hourly variation in $T_{\mathrm{dom}}$ as a function of $W V_{\text {dir }}$ throughout the year is plotted in figure 23. In the winter, $T_{\text {dom }}$ values are longer out of the northwest and shorter out of the south and southwest; and in the summer, $T_{\text {dom }}$ values are more consistently shorter out of the northwest and longer out of the south and southwest. The hourly variation in $W N D_{\text {spd }}$ as a function of $W N D_{\text {dir }}$ throughout the year is plotted in figure 24. In the winter, the variation in $W N D_{\text {dir }}$ is much greater, including a substantial number of high offshore $W N D_{\text {spd }}$ values that are not observed during the rest of the year; in the summer, $W N D_{\text {spd }}$ are commonly higher, and $W N D_{\text {dir }}$ are much more consistently out of the northwest.

Numerous observations during previous El Niño winters (Griggs and Johnson, 1983; Seymour, 1983; Storlazzi and Griggs, 2000) suggest that during intense winter storms, high waves approaching the coast of California are more out of the west and southwest than during normal (non-El Niño) winters. Although statistical analyses looking for mean hourly variations in $W V_{\text {dir }}$ for all hourly 

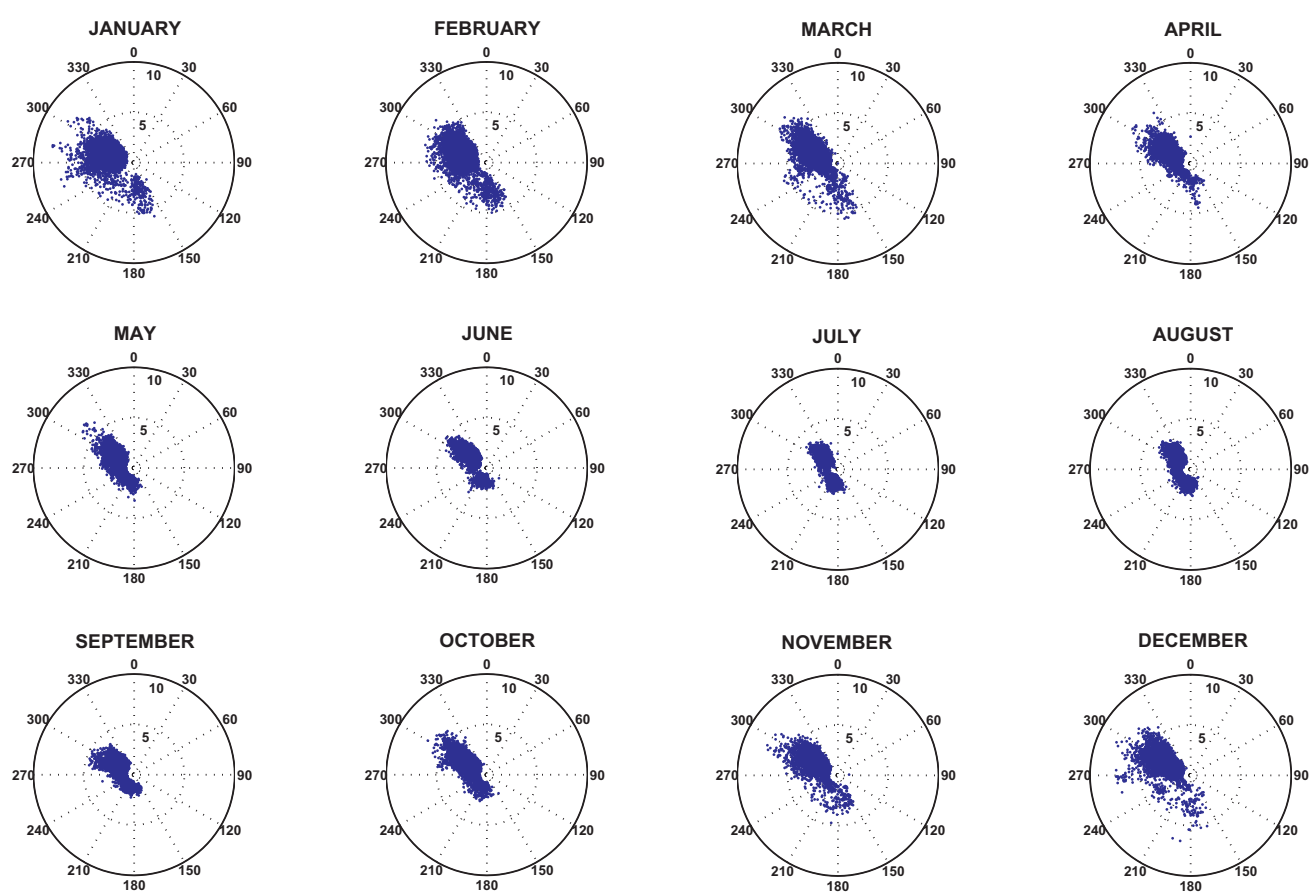

Figure 22. Compass plots of variation in hourly significant wave height $\left(H_{\text {sig }}\right)$ as a function of hourly dominant wave direction ( $W V_{\text {dir }}$ ) at Monterey Bay buoy (sta. 46042, fig. 1) during years when concurrent directional wave and wind data were available (1993-2002). Radial axis, $H_{\text {sig }}$ values (in meters) increase outward $(0-10 \mathrm{~m})$ from center of compass plot; circumferential axis, azimuth of $W V_{\text {dir }}$ values (in degrees). Note greater $H_{\text {sig }}$ and $W V_{\text {dir }}$ variations in winter than in summer.
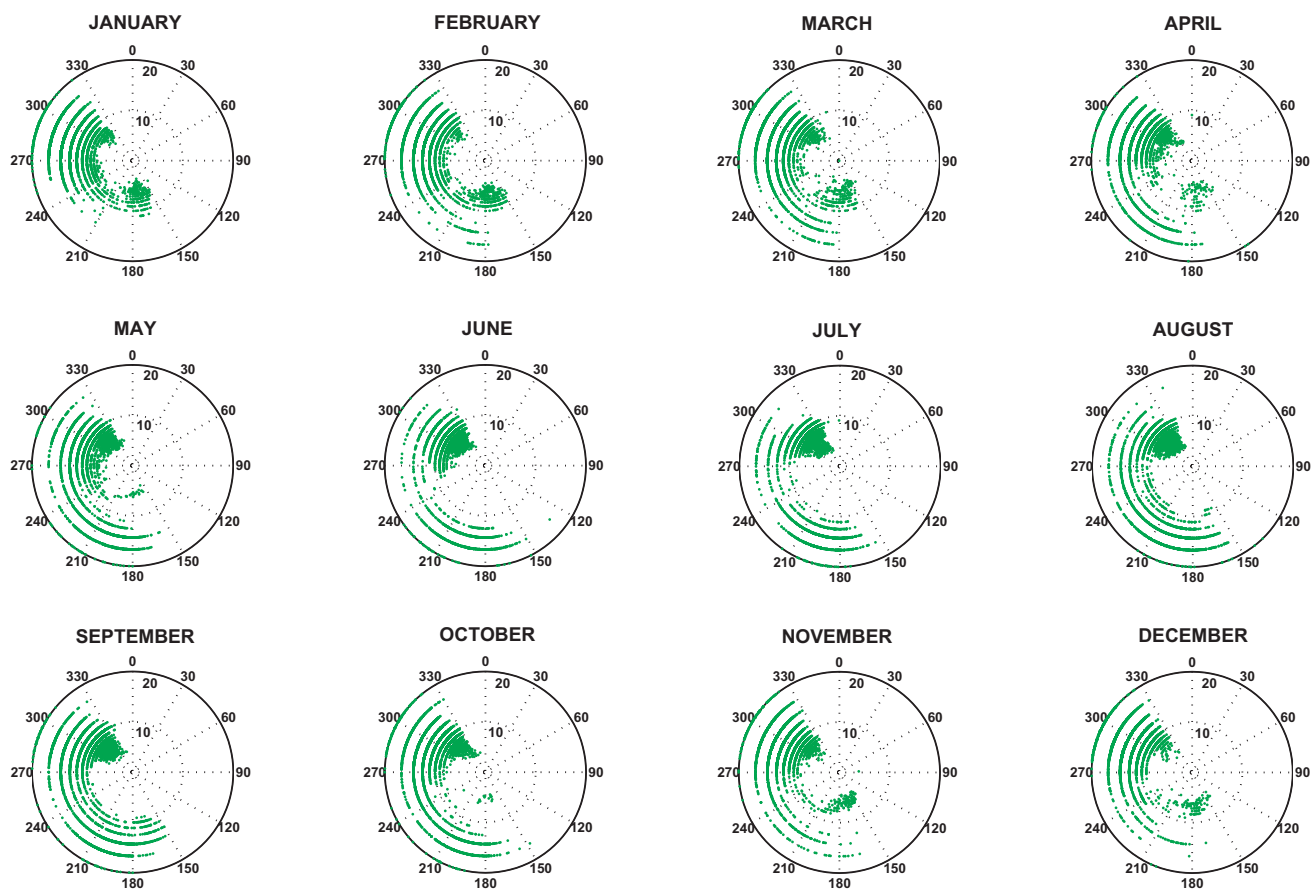

Figure 23. Compass plots of variation in hourly dominant wave period $\left(T_{\text {dom }}\right)$ as a function of hourly dominant wave direction ( $W V_{\text {dir }}$ ) at Monterey Bay buoy (sta. 46042, fig. 1) during years when concurrent directional wave and wind data were available (1993-2002). Radial axis, $T_{\text {dom }}$ values (in seconds) increase outward (0-20 s) from center of compass plot; circumferential axis, azimuth of $W V_{\text {dir }}$ value (in degrees). Note greater $T_{\text {dom }}$ and $W V_{\text {dir }}$ variation in winter, and shorter $T_{\text {dom }}$ values more consistently out of northwest and longer $T_{\text {dom }}$ values more consistently out of southwest in summer. 


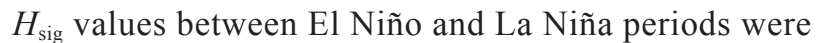
inconclusive, similar analyses for the highest 10 percent of hourly $H_{\text {sig }}$ values during El Niño and La Niña periods reveal a significant departure in hourly $W V_{\text {dir }}$ values (fig. 25). During El Niño periods, the highest 10 percent of hourly $H_{\text {sig }}$ values show a distinct shift to more southerly and southwesterly directions relative to La Niña periods, likely resulting in a more direct impact of waves on California's generally southwest facing coastline, increasing wave-induced setup, and a change in the general southerly direction of longshore sediment transport, as suggested by the USGS/UCSC/NASA/NOAA Collaborative Research Group (1998) and Storlazzi and Griggs (2000).

In an attempt to generalize wave patterns along the central California coast, we synthesized more than 2,800,000 hourly observations of $H_{\text {sig }}, T_{\text {dom }}, W V_{\text {dir }}, W N D_{\text {spd }}$, and $W N D_{\text {dir }}$ from the Monterey Bay buoy (sta. 46042, fig. 1) collected over the years 1993-2002, when concurrent directional wave and wind data were available (fig. 26). Extratropical lows and cold fronts in the North Pacific generate long- $T_{\text {dom }}$ swell that impacts the study area (fig. 1) from the west and northwest, with a general $W V_{\text {dir }}$ of azimuth $290^{\circ}$ and a $W V_{\text {dir }}$ range of azimuths $210-330^{\circ}$, which we refer to as North Pacific Swell. These waves have $H_{\text {sig }}$ values of 2 to $10 \mathrm{~m}$ and $T_{\text {dom }}$ values of 10 to $25 \mathrm{~s}$, with the largest $H_{\text {sig }}$ and longest $T_{\text {dom }}$ values during the winter (October-May). Northwest winds generated by the California High blowing over the open ocean and insolationdriven sea breezes generate short- $T_{\text {dom }}$ waves that impact the study area from the northwest, with a general $W V_{\text {dir }}$ of azimuth $310^{\circ}$ and a $W V_{\text {dir }}$ range of azimuths $280-350^{\circ}$, which we refer to as Northwest Wind Waves. These waves have $H_{\text {sig }}$ values of 1 to $4 \mathrm{~m}$ and $T_{\text {dom }}$ values of 3 to $10 \mathrm{~s}$. Although they occur throughout the year, they occur most consistently (90-95 percent of the time) from April to October and less frequently (55-65 percent of the time) in the winter. Storms in the South Pacific and off Central America generate long- $T_{\text {dom }}$ waves that impact the study area from the south and southwest, with a general $W V_{\text {dir }}$ of azimuth $290^{\circ}$ and a $W V_{\text {dir }}$ range of azimuths $150-260^{\circ}$, which we refer to as Southern Swell. These waves have $H_{\text {sig }}$ values of 0.3 to $3 \mathrm{~m}$ and $T_{\mathrm{dom}}$ values of 10 to $25 \mathrm{~s}$. Although they occur throughout the year, they occur most consistently and with the largest $H_{\text {sig }}$ values from April to October, when large storms occur in the South Pacific during the Southern Hemisphere's winter and tropical cyclones develop off Central America. Storms passing through central California generate short- $T_{\text {dom }}$ waves that can impact
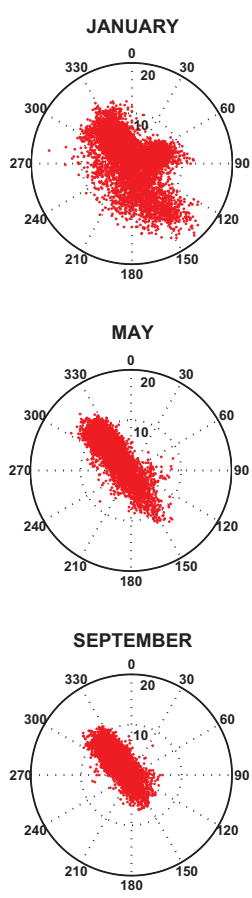
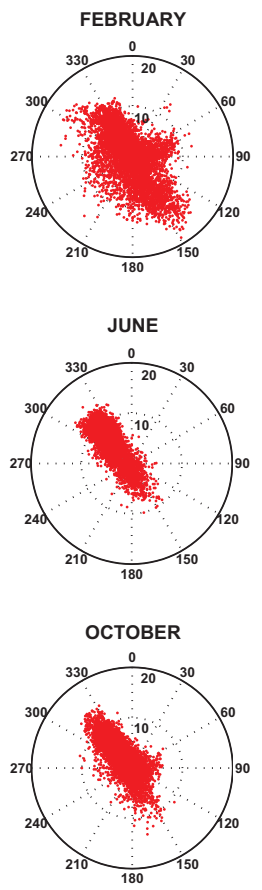
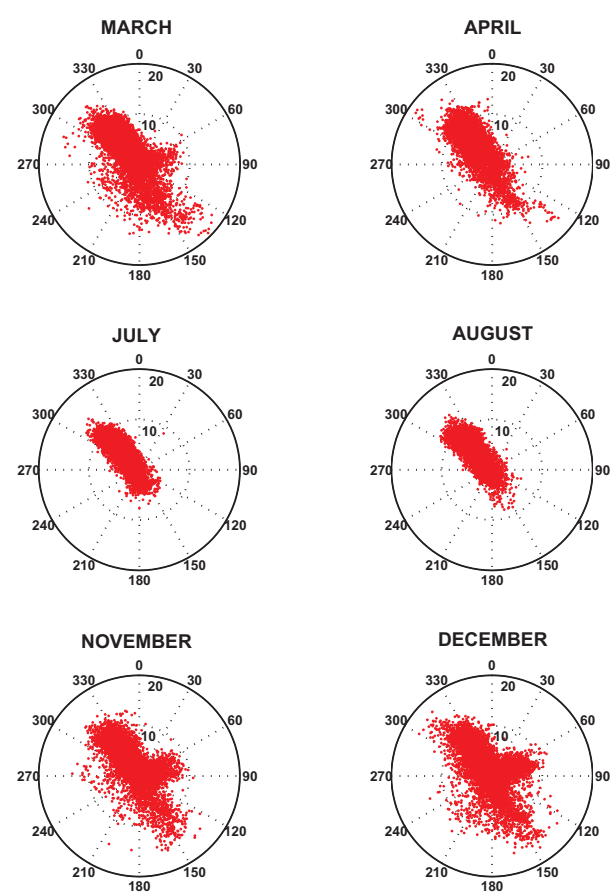

Figure 24. Compass plots of variation in hourly windspeed $\left(W N D_{\text {spd }}\right)$ as a function of hourly wind direction $\left(W N D_{\text {dir }}\right.$ ) at Monterey Bay buoy (sta. 46042, fig. 1) during years when concurrent directional wave and wind data were available (1993-2002). Radial axis, $W N D_{\text {spd }}$ values (in meters per second) increase outward $(0-20 \mathrm{~m} / \mathrm{s})$ from center of compass plot; circumferential axis, azimuth of $W V_{\text {dir }}$ value (in degrees). Note greater $W N D_{\text {spd }}$ and $W N D_{\text {dir }}$ variations in winter and $W N D_{\text {dir }}$ values more consistently out of northwest in summer. 
the study area from all orientations, depending on the latitude of the storm's track; we refer to these waves as Local

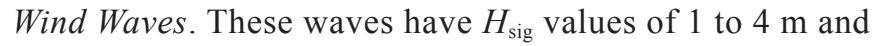
$T_{\text {dom }}$ values of 3 to $10 \mathrm{~s}$ and are most frequent in the winter months (October-May).

\section{Recurrence Intervals}

Recurrence-interval projections of maximum $H_{\text {sig }}$ values are greatest in the northern part of the study area (fig. 1), where calculated extreme values range from 9.01 $\mathrm{m}$ (on a 2-year recurrence interval) to $14.20 \mathrm{~m}$ (on a $100-$ year recurrence interval), as listed in table 2 . Recurrence interval projections of maximum $T_{\text {dom }}$ values are greatest in
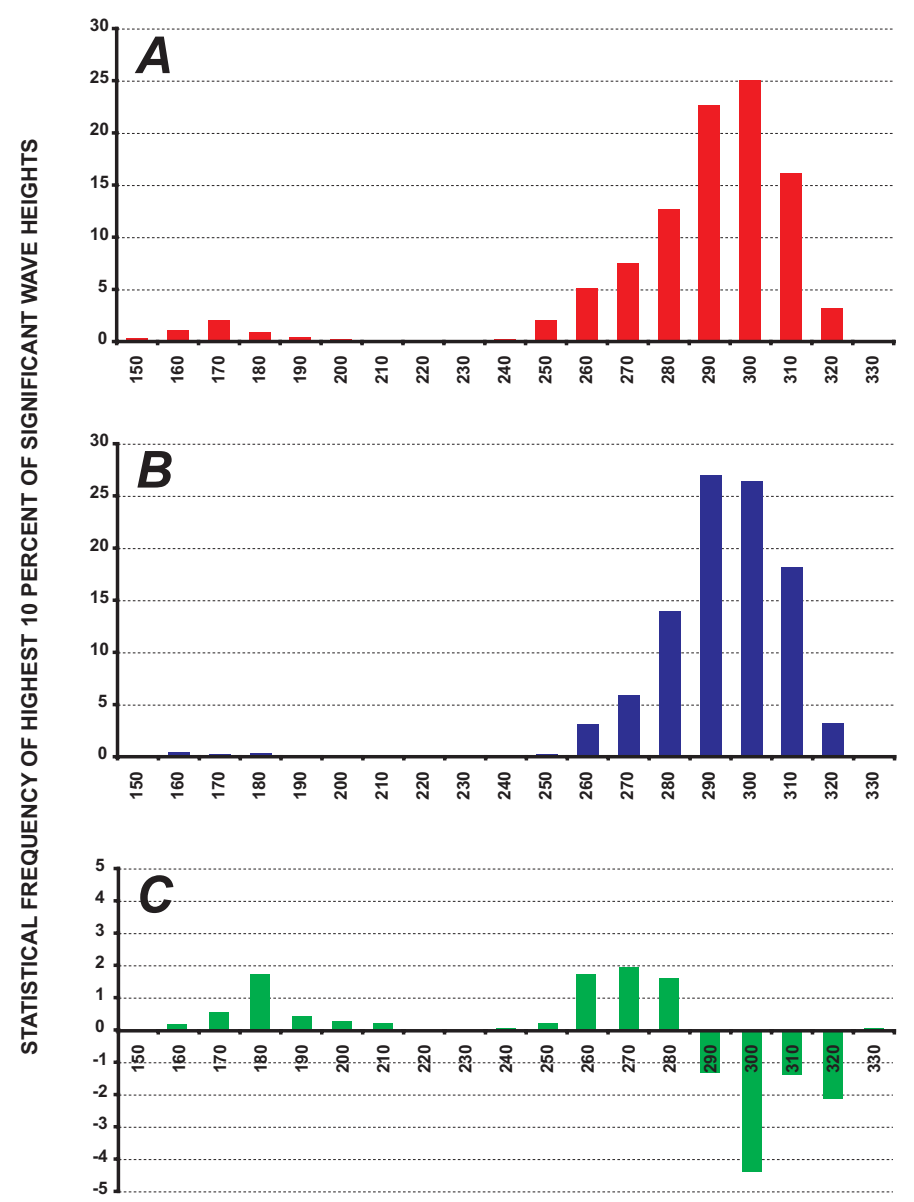

DOMINANT WAVE DIRECTION, IN DEGREES

Figure 25. Bar charts showing frequency distribution of highest 10 percent of hourly significant wave heights $\left(H_{\text {sig }}\right)$ as a function of hourly dominant wave direction $\left(W V_{\text {dir }}\right)$ during El Niño events $(A)$, La Niña events $(B)$, and the change in $W V_{\text {dir }}$ distribution between El Niño and La Niña events $(C)$, from observations at Monterey Bay buoy (sta. 46042, fig. 1) during years when directional wave data were available (1993-2002). Fewer of the largest $H_{\text {sig }}$ values are out of the northwest, and more of the largest $H_{\text {sig }}$ values are out of the west and southwest, during El Niño events than during La Niña events.
Table 2. Recurrence-interval projections of maximums of oceangraphic and meteorologic parameters.

[See figure 1 for locations]

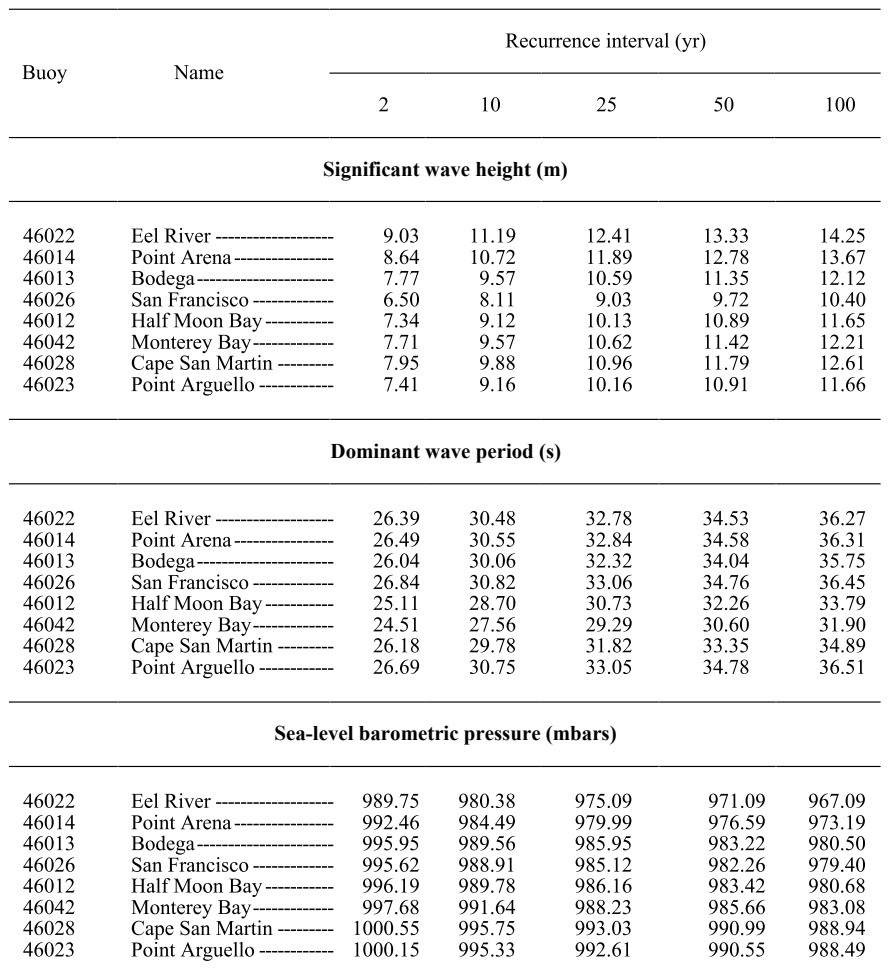

\begin{tabular}{|c|c|c|c|c|c|c|}
\hline \multicolumn{7}{|c|}{ Sea-surface water temperature $\left({ }^{\circ} \mathrm{C}\right)$} \\
\hline $\begin{array}{l}46022 \\
46014 \\
46013 \\
46026 \\
46012 \\
46042 \\
46028 \\
46023\end{array}$ & 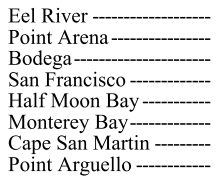 & $\begin{array}{l}17.43 \\
17.62 \\
17.18 \\
18.07 \\
18.05 \\
18.45 \\
19.06 \\
20.50\end{array}$ & $\begin{array}{l}19.70 \\
19.69 \\
19.27 \\
20.28 \\
20.05 \\
20.63 \\
21.21 \\
22.97\end{array}$ & $\begin{array}{l}20.99 \\
20.86 \\
20.45 \\
21.53 \\
21.18 \\
21.87 \\
22.42 \\
24.37\end{array}$ & $\begin{array}{l}21.96 \\
21.74 \\
21.35 \\
22.47 \\
22.03 \\
22.80 \\
23.34 \\
25.42\end{array}$ & $\begin{array}{l}22.93 \\
22.62 \\
22.24 \\
23.41 \\
22.88 \\
23.73 \\
24.26 \\
26.47\end{array}$ \\
\hline \multicolumn{7}{|c|}{ Windspeed (m/s) } \\
\hline $\begin{array}{l}46022 \\
46014 \\
46013 \\
46026 \\
46012 \\
46042 \\
46028 \\
46023\end{array}$ & 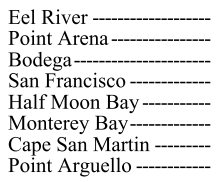 & $\begin{array}{l}25.25 \\
21.42 \\
20.74 \\
22.67 \\
21.91 \\
19.71 \\
17.94 \\
19.13\end{array}$ & $\begin{array}{l}31.72 \\
25.63 \\
24.27 \\
27.08 \\
26.78 \\
23.98 \\
21.05 \\
22.93\end{array}$ & $\begin{array}{l}35.38 \\
28.01 \\
26.27 \\
29.56 \\
29.53 \\
26.39 \\
22.80 \\
25.08\end{array}$ & $\begin{array}{l}38.14 \\
29.80 \\
27.78 \\
31.44 \\
31.61 \\
28.22 \\
24.13 \\
26.70\end{array}$ & $\begin{array}{l}40.90 \\
31.60 \\
29.28 \\
33.32 \\
33.68 \\
30.04 \\
25.45 \\
28.32\end{array}$ \\
\hline
\end{tabular}

the central part of the study area, where calculated extreme values range from $26.84 \mathrm{~s}$ (on a 2-year recurrence interval) to $36.45 \mathrm{~s}$ (on a 100-year recurrence interval). Recurrence interval projections of maximum $S L B_{\text {pres }}$ values are higher in the southern part of the study area, where calculated extreme values are 1000.35 mbars (on a 2-year recurrence interval) and 988.79 mbars (on a 100-year recurrence interval), and lower in the northern part, where calculated extreme values are 989.74 mbars (on a 2-year recurrence interval) and 967.17 mbars (on a 100-year recurrence interval). Recurrence-interval projections of maximum $W_{\text {temp }}$ 


\section{North Pacific Swell} GENERATION:

Storms in the North Pacific, mid-latitude lows, and cold fronts

OCCURRENCE:

Throughout the year; largest in October-May; largest waves to impact the region

HEIGHT: 2-10 m

PERIOD: 10-25 s

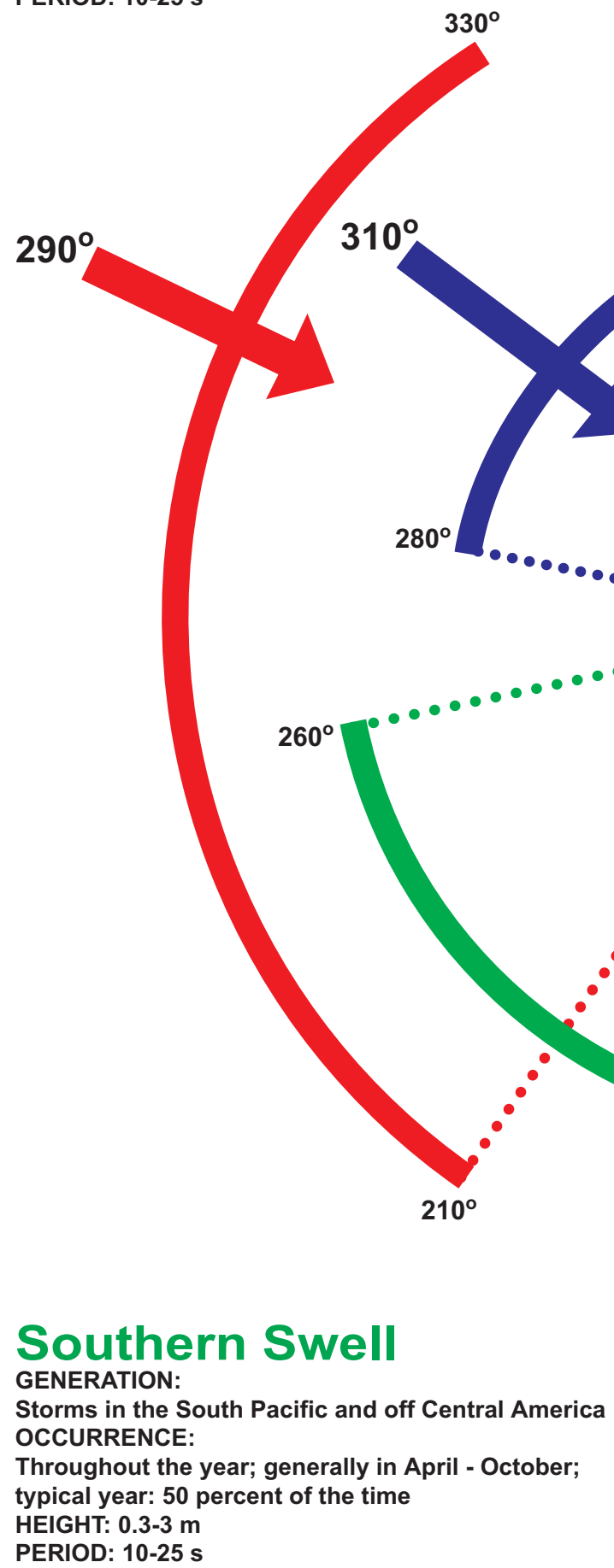

\section{Northwest Wind Waves} GENERATION:

Northwest winds generated by the California

High blowing over the open ocean; sea breezes OCCURRENCE:

Throughout the year; dominant in April-October; summer: $\mathbf{9 0 - 9 5}$ percent, winter: $55-65$ percent of the time HEIGHT: $1-4 \mathrm{~m}$

PERIOD: $3-10 \mathrm{~s}$ 
values are greater in the southern part of the study area than in the northern part, where calculated extreme values are $21.98^{\circ} \mathrm{C}$ and $18.42^{\circ} \mathrm{C}$, respectively (on a 2 -year recurrence interval), but greatest in the central part, where the calculated extreme value is $29.44^{\circ} \mathrm{C}$ (on a 100 -year recurrence interval). Finally, recurrence-interval projections of maximum $W N D_{\text {spd }}$ values are greatest in the northern part of the study area, where calculated extreme values range from $25.31 \mathrm{~m} / \mathrm{s}$ (on a 2-year recurrence interval) to $40.94 \mathrm{~m} / \mathrm{s}$ (on a 100 -year recurrence interval).

\section{Discussion}

Although many studies have documented the impacts of El Niño and La Niña events with respect to the California coastline, none has documented how these events specifically affect the "transition zone" off central California and their implications for physical and biologic processes. The results of this study indicate significant statistical trends over the study period for almost all oceanographic and meteorologic parameters. Storms during normal winter months typically track across the Northeast Pacific, resulting in larger mean $H_{\text {sig }}$ values and shorter mean $T_{\text {dom }}$ values in the northern part of the study area

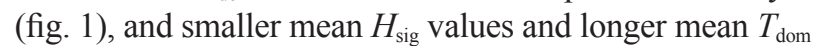
values in the southern part. In addition, $W N D_{\text {dir }}$ variation is generally greater (increased $W N D_{\text {wsw }}$ values) in the northern part of the study area, as westerly and southwesterly winds are associated with winter-storm activity (Bixby, 1962) and the relative latitude of the California High during the summer. During normal winter months, storminess tends to be greatest in December and January. The development of the California High during normal summer months results in lower mean $H_{\text {sig }}$ and $T_{\text {dom }}$ values throughout the study area, as wave conditions are milder in the summer. Spatial variation in mean $S L B_{\text {pres }}$ values is greater, as barometric pressures are higher in the northern part of the study area because of the position of the California High. The lower mean $S L B_{\text {pres }}$ values in the southern part of the study area are due not only to tropical-cyclone activity off Mexico and Central America during normal summer months but also to the Mexican monsoon, a seasonal reversal of atmospheric circulation that transports moisture from the Gulf of California to the Southwestern United States. As expected, the spatial variation in mean $W_{\text {temp }}$ values shows cooler temperatures in the northern part of the study area and warmer temperatures in the southern part year round.

During El Niño events, wind and wave behavior changes significantly throughout the "transition zone" off central California. Winter El Niño storms generally track farther to the south, striking the California coastline more directly

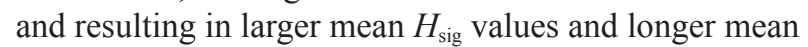
$T_{\text {dom }}$ values throughout central California, including a higher percentage of $W V_{\text {dir }}$ values from the south and southwest. In addition, lower mean $S L B_{\text {pres }}$ values, larger mean $S L B_{\text {pres }}$ variations, and higher $W N D_{\text {wsw }}$ values also suggest more frequent and bigger storms tracking throughout the study area during El Niño events. In contrast, La Niña events generally impact the "transition zone" less directly, as storm tracks are farther north, resulting in smaller mean $H_{\text {sig values and more frequent }}$ northwesterly $W V_{\text {dir }}$ values than during El Niño winter months (but sometimes still larger than during normal winter months) and smaller $S L B_{\text {pres }}$ and $W N D_{\text {wsw }}$ variations. Thus, La Niña winter months bring less frequent and earlier storminess than either El Niño or normal months, generally resulting in less coastal erosion (Storlazzi and Griggs, 2000).

Long-term trends of mean $H_{\text {sig values on average }}$ increased by $2.0 \mathrm{~cm} / \mathrm{yr}$ throughout central California (fig. 1) over the study period. These results contradict previous observations of no significant long-term increase in $H_{\text {sig }}$ values off central California (Allan and Komar, 2000). Lower mean $S L B_{\text {pres }}$ values, longer mean $T_{\text {dom }}$ values, and increasing mean $W N D_{\text {spd }}$ and $W N D_{\text {wsw }}$ values suggest increasing storminess and storm intensity over the study period, as noted by Graham and Diaz (2001). Long-term trends suggest a decreasing $W_{\text {temp }}$ variation over the study period, resulting in a smaller north-tosouth longshore temperature gradient and a more nearly homogeneous $W_{\text {temp }}$ distribution along the central California coast.

These long-term trends of increased storminess, lower mean $S L B_{\text {pres }}$ values, and cooler mean $W_{\text {temp }}$ values in the Northeast Pacific concur with the suggestions by Hare and Mantua (2002) that the Pacific Decadal Oscillation (PDO), an interdecadal change in climate, has begun to shift from a warm phase to a cool phase. Because its phases generally last 20-30 years, with the latest warm phase starting in 1977, some workers believe that a PDO phase shift occurred with the demise of the 1997/98 El Niño and the subsequent inception of the 1998/99 La Niña event, as discussed by Hare and Mantua (2002). A warm PDO phase is marked by unusually warm mean $W_{\text {temp }}$ values along the U.S. west coast and high mean $S L B_{\text {pres }}$ values over western North America, whereas a cold PDO phase exhibits cooler mean $W_{\text {temp }}$ values along the Northeast and tropical Pacific. A shift to a cool PDO phase would result in more La Niña-like conditions and thus stronger and longer La Niña events and shorter, weaker El Niño events (Hare and Mantua, 2002).

\section{Conclusions}

We have analyzed more than 20 years of hourly deepwater buoy data from off central California to investigate long-term trends and compute statistically significant probability estimates of the behavior of measured oceanographic and meteorologic parameters during different climatic regimes (table 3). Significantly different trends were observed in the datasets during El Niño and La Niña months, reinforcing longheld but relatively unsupported theories on the spatial and temporal variations in oceanographic and meteorologic forcing along the central California coast during different ENSO phases. Because storms generally track directly across California during El Niño months, mean $H_{\text {sig }}$ values are higher, with $H_{\text {sig }}$ values greater than $4 \mathrm{~m}$ as much as 30 percent more frequent than average. In addition, mean $T_{\mathrm{dom}}$ values are shorter, 
Table 3. Long-term trends of oceanographic and meteorologic parameters throughout the study area over the study period (1980-2002).

[N.S., not statistically significant]

\begin{tabular}{cccccc}
\hline Parameter & $\begin{array}{c}\text { Part of } \\
\text { study area }\end{array}$ & Mean & Minimum & Maximum & $\begin{array}{c}\text { Standard } \\
\text { deviation }\end{array}$ \\
\hline $\begin{array}{c}\text { Significant wave height } \\
\text { (cm/yr). }\end{array}$ & North & +2.0 & +0.9 & +5.7 & +0.6 \\
& Central & +2.1 & +1.1 & +6.8 & +0.8 \\
& South & +1.9 & +0.2 & +7.7 & +1.0 \\
$\begin{array}{c}\text { Dominant wave period } \\
\text { (s/yr). }\end{array}$ & North & +0.039 & +0.001 & +0.061 & +0.006 \\
& Central & +0.025 & N.S. & +0.037 & N.S. \\
Sea-level barometric & South & +0.045 & +0.030 & +0.035 & N.S. \\
pressure (mbar/yr). & Corth & -0.04 & -0.14 & N.S. & N.S. \\
& Coutral & -0.05 & N.S. & N.S. & N.S. \\
Sea-surface water tem- & North & -0.06 & N.S. & N.S. \\
perature $\left({ }^{(} \mathrm{C} /\right.$ yr). & Central & N.S. & +0.01 & +0.02 & N.S. \\
& South & -0.03 & +0.02 & N.S. & -0.01 \\
Frequency of winds from & North & +0.34 & -- & -- & -0.01 \\
the southwest & Central & N.S. & -- & -- & -- \\
(percent/yr). & South & +0.23 & -- & -- & -- \\
\hline
\end{tabular}

mean $S L B_{\text {pres }}$ values are lower, and mean $W N D_{\text {wsw }}$ values are higher, suggesting greater storminess and storm proximity.

These intense wave conditions impact the "transition zone" off central California most significantly during El Niño

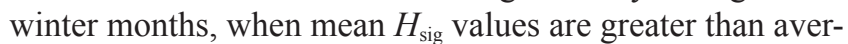
age, mean $W N D_{\text {wsw }}$ values are higher than average, and mean $W_{\text {temp }}$ values are warmer than average. In contrast, their impact is less direct during La Niña winter months, when mean $H_{\text {sig }}$ values are lower than during El Niño months and the largest storms generally strike earlier in the winter. Mean $W_{\text {temp }}$ values are cooler than average during the spring and summer as northwesterly winds predominate (decreased $W N D_{\text {wsw }}$ values).

Our study indicates that mean $H_{\text {sig }}$ and $W N D_{\text {wsw }}$ values increased, mean $T_{\text {dom }}$ and $S L B_{\text {pres }}$ values decreased, and mean $W_{\text {temp }}$ variation was smaller throughout the study area (fig. 1) over the study period. These results indicate that the "transition zone" off central California (from high-energy wave conditions in the Pacific Northwest to milder wave conditions off southern California) is actually more energetic than once believed. With the advantage of seasonal, interannual, and long-term data, our study anticipates a better understanding of the influence of spatial and temporal variations in oceanographic and meteorologic forcing on physical, geologic, and biologic processes along the central California coast.

\section{Acknowledgments}

This research is part of the USGS Central California Regional Synthesis Project and Benthic Habitats Project's effort to better understand the impact of geologic and oceanographic processes on central California's shoreline and nearshore ecosystems. We thank Jane Reid (USGS), who overextended herself in helping us with geospatial data analysis and numerous small but extremely important tasks. We also thank Bruce Richmond (USGS) and Guy Cochrane (USGS), who contributed numerous excellent suggestions and timely reviews of the manuscript. George Havach of the USGS Western Publication Group deserves special thanks for working hard with us to get this report into the correct format.

\section{References Cited}

Allan, J.C., and Komar, P.D., 2000, Are ocean wave heights increasing in the eastern North Pacific?: Eos (American Geophysical Union Transactions), v. 81, p. 561, 566-567.

Anima, R.J., Eittreim, S.L., Edwards, B.D., and Stevenson, A.J., 2002, Nearshore morphology and late Quaternary geologic framework of the northern Monterey Bay Marine Sanctuary, California: Marine Geology, v. 181, no. 1-3, p. 35-54.

Bixby, H.C., 1962, Storms causing harbor and shoreline damage through wind and waves, Monterey California: Monterey, California, Naval Postgraduate School, Masters thesis, 145 p.

Brewer, Isaac, and Jackson, P.J., 2000, A spatial and temporal analysis of Northwest Pacific coast storms 1973-1998; examining the variability of the El Niño anomaly: Oregon Academy of Science Conference, Salem, Oreg., 1999, paper.

Bromirski, P.D., Cayan, D.R., and Flick, R.E., in press, Wave spectral energy variability in the Northeast Pacific: Journal of Geophysical Research.

Carter, D.J.T., Challenor, P.G., Ewing, J.A., Pitt, E.G., Srokosz, M.A., and Tucker, M.J., 1986, Estimating wave climate parameters for engineering applications (Offshore Technology Report 86-228): London, HMSO, 130 p.

Chelton, D.B., Bernal, P.A., and McGowan, J.A., 1982, Largescale interannual physical and biological interaction in the California Current: Journal of Marine Research, v. 40, no. 4, p. 1095-1125.

Dingler, J.R., and Reiss, T.E., 2002, Changes to Monterey Bay beaches from the end of the 1982-1983 El Niño: Marine Geology, v. 181, no. 1-3, p. 249-263.

Edwards, B.D., 2002. Variations in sediment texture on the northern Monterey Bay National Marine Sanctuary continental shelf: Marine Geology, v. 181, no. 1-3, p. 83-100.

Glantz, M.H., 2001, Currents of change: Impacts of El Niño and La Niña on climate and society ( $2 \mathrm{~d}$ ed.): Cambridge, U.K., Cambridge University Press, $252 \mathrm{p}$.

Graham, N.E., and Diaz, H.F., 2001, Evidence for intensification of North Pacific winter cyclones since 1948: American Meteorological Society Bulletin, v. 82, p. 18691893.

Griggs, G.B., and Johnson, R.E., 1979, Coastal erosion, Santa Cruz County: California Geology, v. 32, no. 4, p. 67-76.

Griggs, G.B., and Johnson, R.E., 1983, Impact of 1983 storms on the coastline of Northern Monterey Bay, Santa Cruz County: California Geology, v. 36, no. 8, p. 163-174.

Hare, S.R., and Mantua, N.J., 2002, Empirical evidence for North Pacific regime shifts in 1977 and 1989: Progress in Oceanography, v. 24, p. 6-14. 
Inman, D.L., 1991, Budget of sediment and prediction of the future state of the coast, chap. 9 of State of the coast report, San Diego region, coast of California storm and tidal waves study: U.S. Army Corps of Engineers, Los Angeles District, v. 1.

Inman, D.L., and Jenkins, S.A., 1997, Changing wave climate and littoral drift, chap. 73 of Magoon, O.T., ed., Taking a look at California's ocean resources; an agenda for the future: California and World Ocean '97 Conference, San Diego, Calif., Proceedings, v. 1, p. 539-549.

Komar, P.D., 1998, El Niño and coastal erosion in the Pacific Northwest: Oregon Geology, v. 60, no. 3, p. 57-64.

Kudela, R.M., and Chavez, F.P., 2000, Modeling the impact of the 1992 El Niño on new production in Monterey Bay, California: Deep-Sea Research, pt. 2, v. 47, no. 5-6, p. 1055-1076.

Lynn, R.J., Baumgartner, T.R., Collins, C.A., García, J., Hayward, T.L., Hyrenbach, K.D., Mantyla, A.W., Murphree, Tom, Shankle, Amy, Schwing, F.B., Sakuma, K.M., and Tegner, M.T., 1998, The state of the California Current, 1997-1998; transition to El Niño conditions: California Cooperative Oceanic Fisheries Investigations Reports, v. 39, p. 25-49.

National Data Buoy Center, 2004, Northwest USA historical marine data: URL http://www.ndbc.noaa.gov/maps/ northwest_hist.shtml.

National Marine Consultants, 1960, Wave statistics for seven deep water stations along the California coast: report prepared for U.S. Army Corps of Engineers, Los Angeles and San Francisco Districts, 20 p.

National Oceanic and Atmospheric Administration, Climate Diagnostics Center, 2004, Multivariate ENSO index: URL http://www.cdc.noaa.gov/people/klaus.wolter/MEI/.

Schwing, F.B., Murphree, Tom, deWitt, Lynn, and Green, P.M., 2002, The evolution of oceanographic and atmospheric anomalies in the northeast Pacific during the El Niño and La Niña events of 1995-2001: Progress in Oceanography, v. 54, p. 459-491.
Seymour, R.J., 1983, Extreme waves in California during winter, 1983: California Department of Boating and Waterways Report, $6 \mathrm{p}$.

Seymour, R.J., Strange, R.R., Cayan, D.R., and Nathan, R.A., 1984, Influence of El Niños on California's wave climate: American Society of Civil Engineers, Coastal Engineering Conference, 19th, Houston, Tex., 1984, Proceedings, v. 1, p. 577-592.

Storlazzi, C.D., and Griggs, G.B., 2000, Influence of El NiñoSouthern Oscillation (ENSO) events on the evolution of central California's shoreline: Geological Society of America Bulletin, v. 112, no. 2, p. 236-249.

Storlazzi, C.D., McManus, M.A., and Figurski, J.D., 2003, Long-term high-frequency $\mathrm{ADCP}$ and temperature measurements along central California: Insights into upwelling and internal waves on the inner shelf: Continental Shelf Research, v. 23, p. 901-918.

Storlazzi, C.D., Wingfield, D.K., McManus, M.A., and Carr, M.H., 2004, Variability in oceanographic and meteorologic forcing along Central California and its implications on nearshore physical and biological processes [abs.]: Annual Pacific Climate Workshop on Climate Variability of the Eastern North Pacific and Western North America, 21st, Asilomar, Calif., 2004, Proceedings, p. 36.

USGS/UCSC/NASA/NOAA Collaborative Research Group, 1998, A collaborative program to investigate the impacts of the 1997-98 El Niño winter along the California coast: Shore and Beach, v. 66, no. 3, p. 24-32.

Webster, P.J., and Palmer, T.N., 1997, The past and future of El Niño: Nature, v. 390, no. 6660, p. 562-564.

Wolter, Klaus, and Timlin, M.S., 1998, Measuring the strength of ENSO - how does 1997/98 rank?: Weather, v. 53, p. 315-324.

Wright, L.D., 1987, Shelf-surfzone coupling; diabathic shoreface transport: American Society of Civil Engineers, Coastal Sediments '87, New Orleans, La., 1987, v. 1, p. 25-40. 


\section{Appendix 1. Raw and Calculated Datasets from Eight Buoys Deployed off the Central California Coast by the National Oceanic and Atmospheric Administration's National Data Buoy Center over the Study Period (1980-2002)}

\section{Hourly Raw Data}

The following data were collected from all eight buoys:

1. Wind direction (in degrees)

2. Windspeed (in meters per second)

3. Significant wave height (in meters)

4. Dominant wave period (in seconds)

5. Dominant wave direction (in degrees of azimuth)

6. Sea-level barometric pressure (in millibars)

7. Sea-level air temperature (in degrees Celsius)

8. Sea-surface water temperature (in degrees Celsius)

\section{Monthly Mean Statistics}

The following parameters were calculatedonly for those months with more than 480 hours (20 days) of data. Besides calculating the dataset for all months, data subsets were created for El Niño months, La Niña months, and non-El Niño-La Niña months, on the basis of the MEI:

1. Wind direction (in degrees): minimum, maximum, mean, and standard deviation

2. Windspeed (in meters per second): minimum, maximum, mean, and standard deviation

3. Significant wave height (in meters): minimum, maximum, mean, and standard deviation

4. Dominant wave period (in seconds): minimum, maximum, mean, and standard deviation

5. Dominant wave direction (in degrees of azimuth): minimum, maximum, mean, and standard deviation

6. Sea-level barometric pressure (in millibars): minimum, maximum, mean, and standard deviation

7. Sea-level air temperature (in degrees Celsius): minimum, maximum, mean, and standard deviation

8. Sea-surface water temperature (in degrees Celsius): minimum, maximum, mean, and standard deviation

9. Exceedance (in percent) of significant wave heights greater than 4,8 , and $8 \mathrm{~m}$

10. Exceedance (in percent) of sea-level barometric pressures lower than 1000, 990, and 980 mbars

11. Frequency (in percent) of southerly/southwesterly/westerly wave directions between azimuths $080^{\circ}$ and $270^{\circ}$

12. Frequency (in percent) of southerly/southwesterly/ westerly wave directions between azimuths $070^{\circ}$ and $250^{\circ}$

\section{Recurrence-Interval Projections and Calculated Extreme Values}

The following extreme values calculated on 2-, 10-, 25-, 50 -, and 100-year recurrence intervals are based on FisherTippet type I distributions of monthly extreme values $(n>150)$ :

1. Maximum windspeed (in meters per second)

2. Maximum significant wave height (in meters)

3. Maximum dominant wave period (in seconds)

4. Maximum sea-level barometric pressure (in millibars)

5. Maximum sea-level air temperature (in degrees Celsius)

6. Maximum sea-surface water temperature (in degrees Celsius) 


\section{Appendix 2. Mean Monthly Significant Wave Height at Eight Buoys Deployed by the National Oceanic and Atmospheric Administration's National Data Buoy Center over the Study Period (1980-2002)}

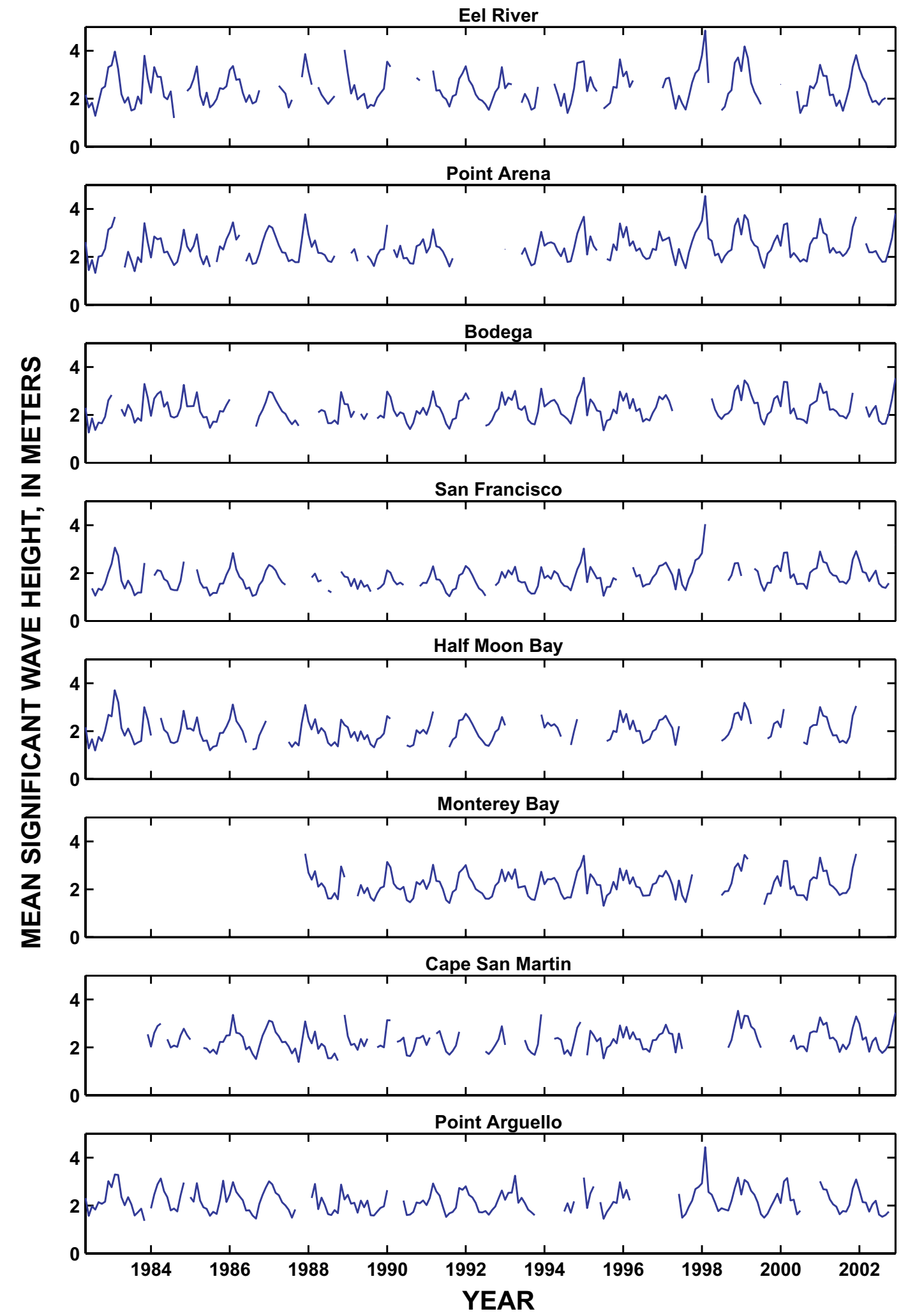


Appendix 3. Mean Monthly Dominant Wave Period at Eight Buoys Deployed by the National Oceanic and Atmospheric Administration's National Data Buoy Center over the Study Period (1980-2002)

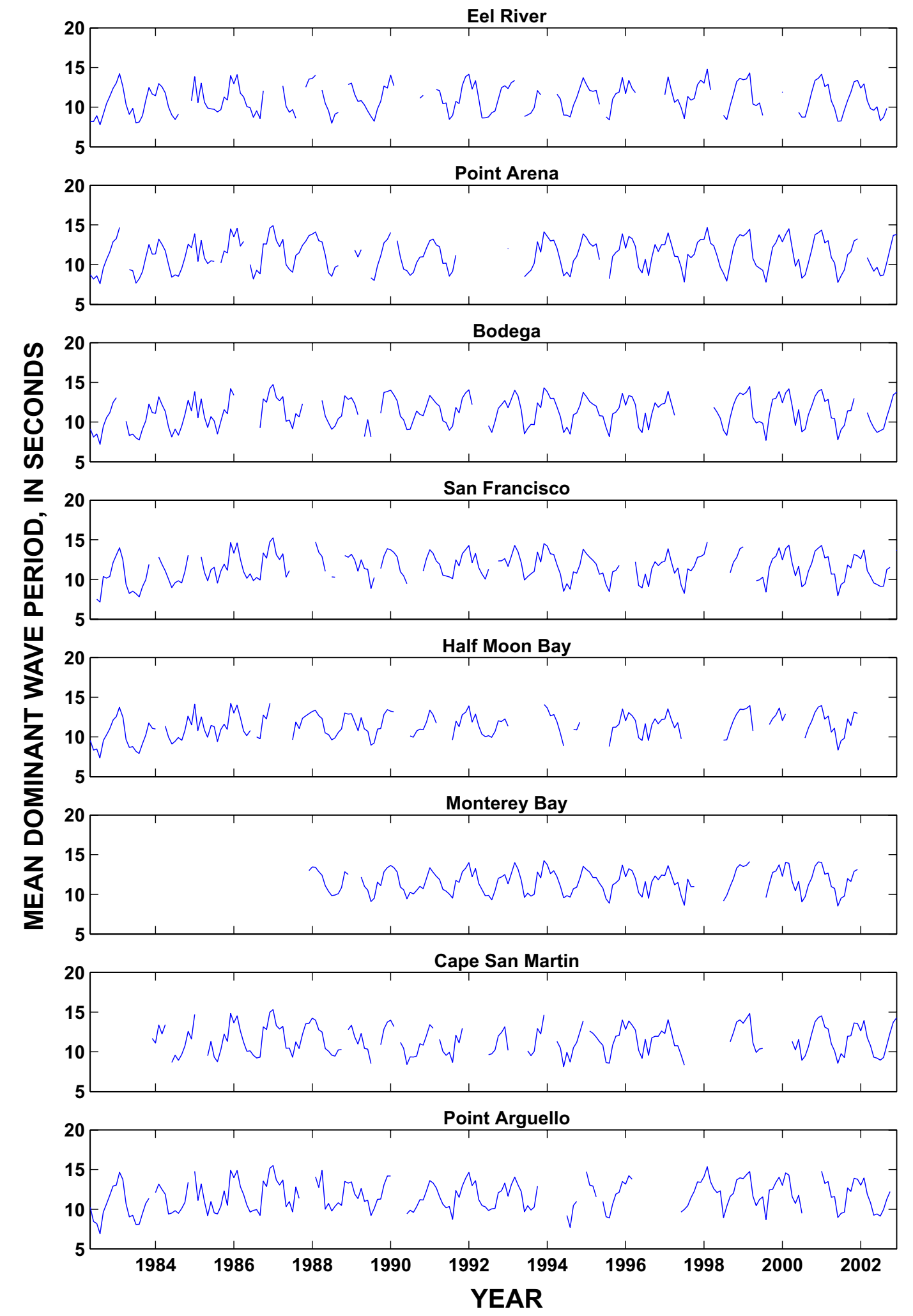


28

Spatial and Temporal Variations in Oceanographic and Meteorologic Forcing Along the Central California Coast

Appendix 4. Mean Monthly Sea-Level Barometric Pressure at Eight Buoys Deployed by the National Oceanic and Atmospheric Administration's National Data Buoy Center over the Study Period (1980-2002)

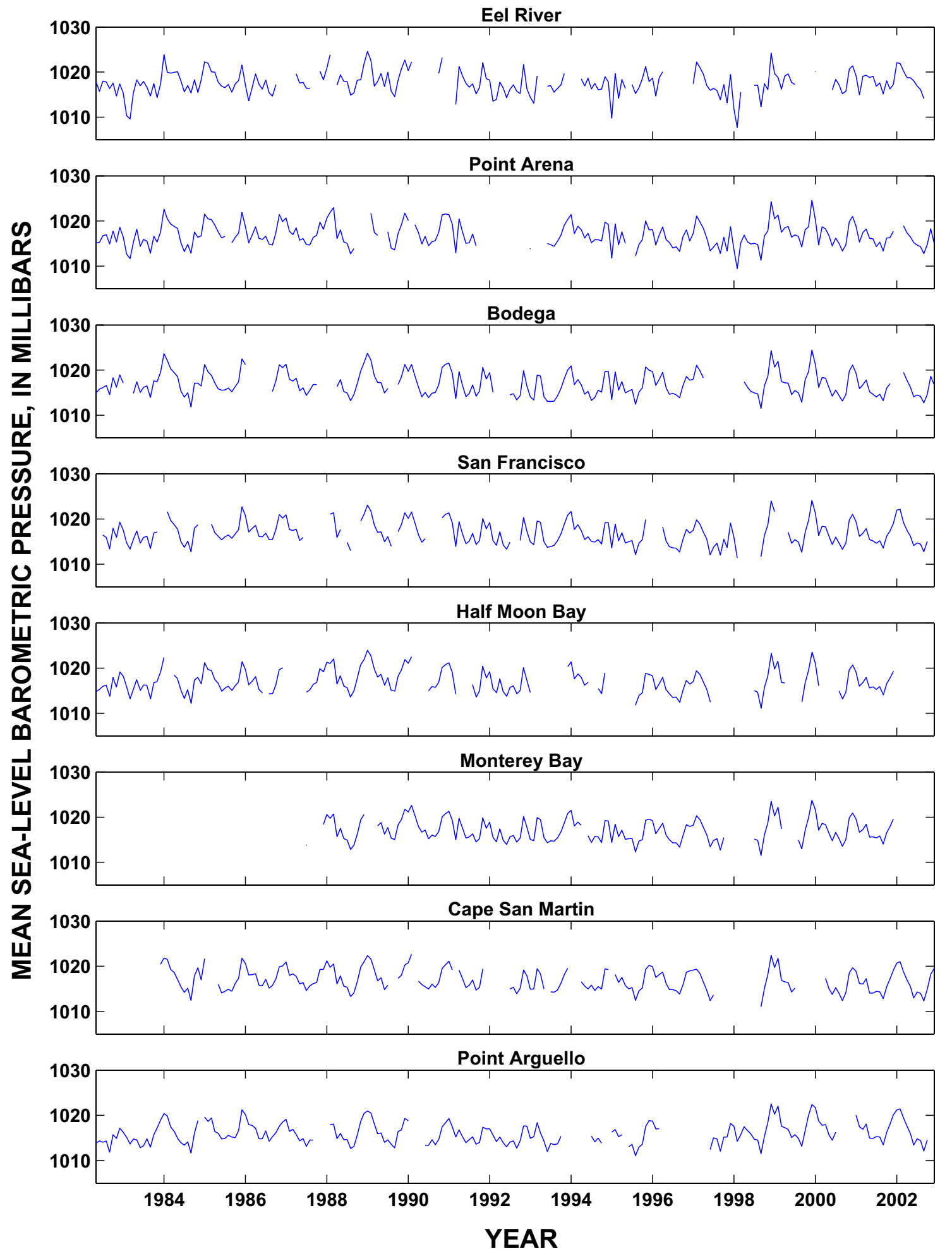


Appendix 5. Mean Monthly Sea-Surface Water Temperature at Eight Buoys Deployed by the National Oceanic and Atmospheric Administration's National Data Buoy Center over the Study Period (1980-2002)

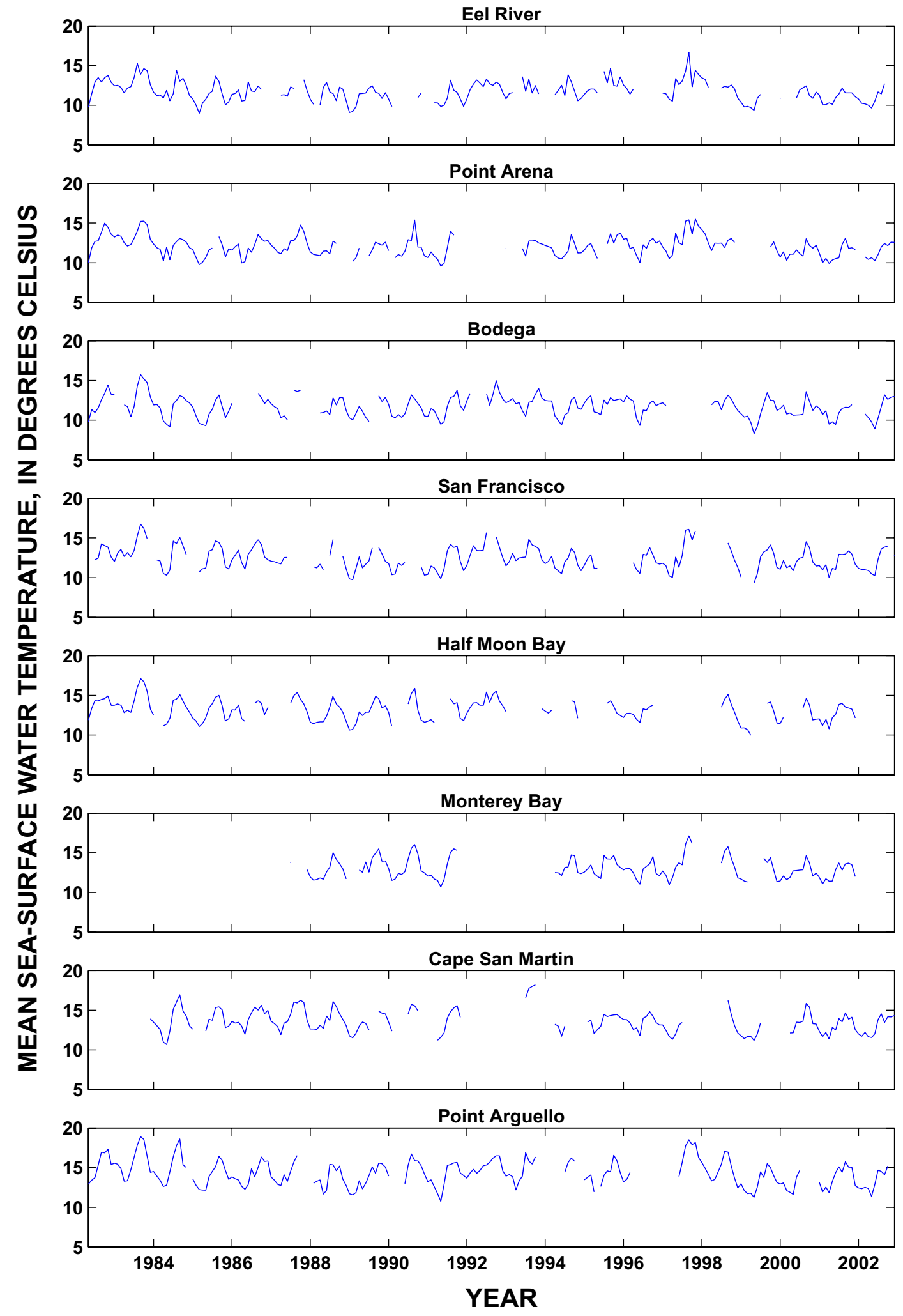




\section{Appendix 6. Mean Monthly Windspeed at Eight Buoys Deployed by the National Oceanic and Atmospheric Administration's National Data Buoy Center over the Study Period (1980-2002)}

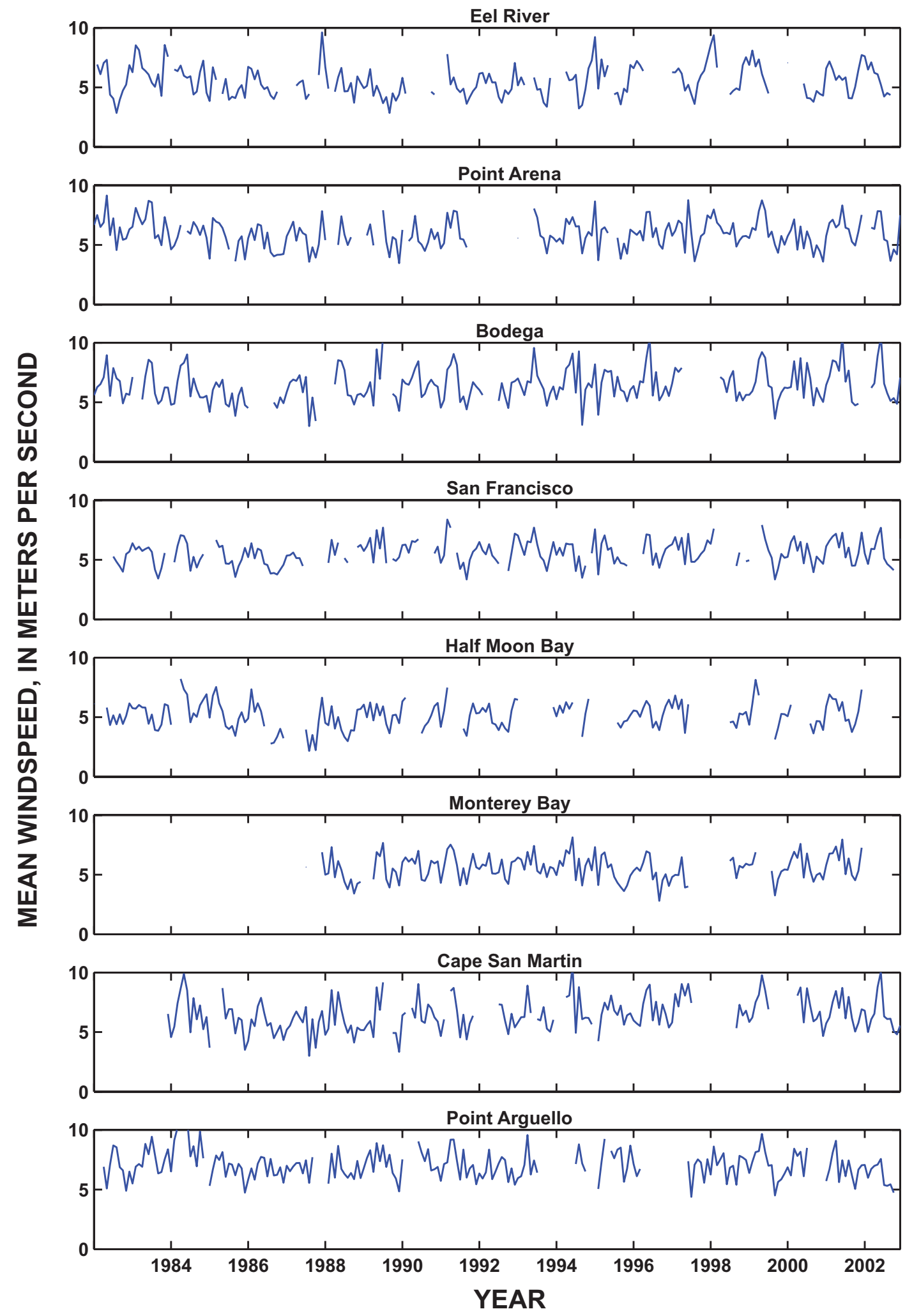


Appendix 7. Mean Monthly Frequency of Winds from the Southwest at Eight Buoys Deployed by the National Oceanic and Atmospheric Administration's National Data Buoy Center over the Study Period (1980-2002)

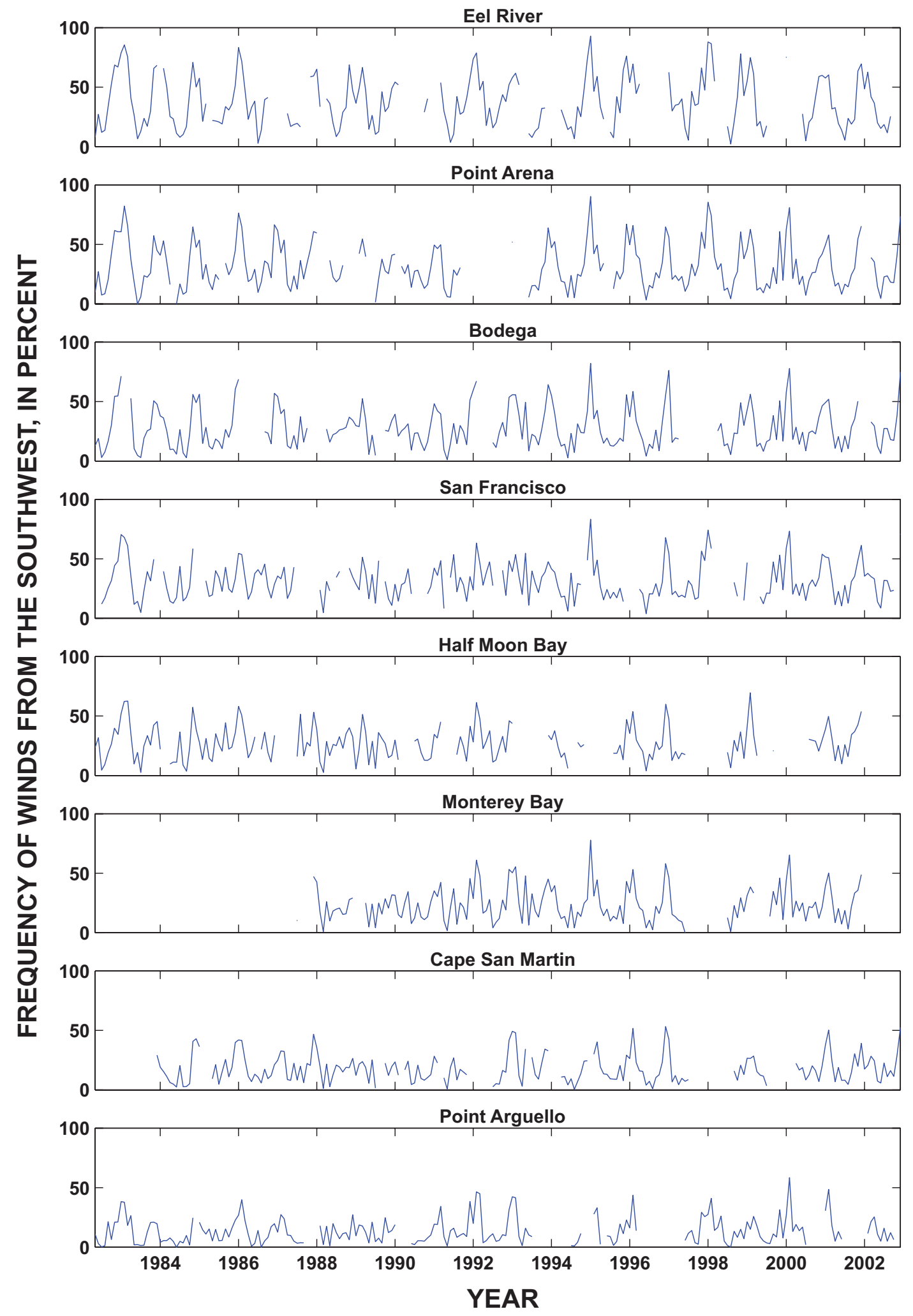


Appendix 8. Mean \pm 1 Standard Deviation Monthly Statistics of Oceanographic and Meteorologic Parameters at the Eel River Buoy (sta. 46022, fig. 1) for All Months and for El Niño and La Niña Months

\begin{tabular}{|c|c|c|c|c|c|}
\hline Month & $\begin{array}{c}\text { Significant wave } \\
\text { height } \\
(\mathrm{m})\end{array}$ & $\begin{array}{l}\text { Dominant wave } \\
\text { period } \\
\text { (sec) }\end{array}$ & $\begin{array}{l}\text { Sea-level barometric } \\
\text { pressure } \\
\text { (mbars) }\end{array}$ & $\begin{array}{c}\text { Sea-surface water } \\
\text { temperature } \\
\left({ }^{\circ} \mathrm{C}\right)\end{array}$ & $\begin{array}{l}\text { Frequency of winds } \\
\text { from the southwest } \\
\text { (pct) }\end{array}$ \\
\hline \multicolumn{6}{|c|}{ All months } \\
\hline January (1) & $3.06 \pm 0.54$ & $12.91 \pm 0.96$ & $1018.57 \pm 3.52$ & $11.22 \pm 0.40$ & $72.01 \pm 0.22$ \\
\hline February (2) & $3.09 \pm 0.40$ & $12.91 \pm 1.12$ & $1017.70 \pm 4.06$ & $11.03 \pm 0.76$ & $66.86 \pm 0.24$ \\
\hline March (3) & $2.90 \pm 0.21$ & $12.39 \pm 0.69$ & $1016.76 \pm 3.00$ & $11.03 \pm 0.67$ & $62.37 \pm 0.24$ \\
\hline April (4) & $2.43 \pm 0.28$ & $11.19 \pm 0.81$ & $1018.83 \pm 1.11$ & $10.97 \pm 0.71$ & $48.64 \pm 0.26$ \\
\hline May (5) & $2.09 \pm 0.14$ & $9.95 \pm 0.79$ & $1018.18 \pm 1.25$ & $11.18 \pm 1.05$ & $41.08 \pm 0.36$ \\
\hline June (6) & $1.99 \pm 0.25$ & $9.43 \pm 0.76$ & $1017.08 \pm 1.15$ & $11.69 \pm 0.80$ & $33.83 \pm 0.36$ \\
\hline July (7) & $1.81 \pm 0.32$ & $8.75 \pm 0.42$ & $1017.20 \pm 1.24$ & $12.14 \pm 0.86$ & $20.31 \pm 0.35$ \\
\hline August (8) & $1.66 \pm 0.22$ & $8.97 \pm 0.45$ & $1016.54 \pm 0.86$ & $12.94 \pm 0.96$ & $29.36 \pm 0.34$ \\
\hline September (9) & $1.92 \pm 0.16$ & $9.93 \pm 0.68$ & $1015.12 \pm 0.73$ & $12.75 \pm 0.97$ & $42.42 \pm 0.29$ \\
\hline October (10) & $2.33 \pm 0.33$ & $11.30 \pm 0.46$ & $1017.42 \pm 1.39$ & $12.27 \pm 1.22$ & $47.24 \pm 0.28$ \\
\hline November (11) & $2.84 \pm 0.54$ & $12.34 \pm 0.76$ & $1018.52 \pm 3.06$ & $12.06 \pm 1.23$ & $63.43 \pm 0.27$ \\
\hline December (12) & $3.22 \pm 0.59$ & $13.04 \pm 0.88$ & $1019.35 \pm 2.60$ & $11.63 \pm 1.12$ & $70.05 \pm 0.21$ \\
\hline \multicolumn{6}{|c|}{ El Niño months } \\
\hline January (1) & $3.45 \pm 0.25$ & $13.34 \pm 0.53$ & $1015.19 \pm 4.52$ & $11.77 \pm 1.17$ & $83.08 \pm 0.13$ \\
\hline February (2) & $3.86 \pm 1.04$ & $13.76 \pm 1.31$ & $1010.52 \pm 2.91$ & $12.58 \pm 0.65$ & $87.69 \pm 0.09$ \\
\hline March (3) & $2.82 \pm 0.38$ & $12.71 \pm 0.59$ & $1013.04 \pm 3.07$ & $12.39 \pm 0.24$ & $69.49 \pm 0.24$ \\
\hline April (4) & $2.30 \pm 0.21$ & $11.34 \pm 1.20$ & $1017.57 \pm 2.13$ & $12.01 \pm 1.03$ & $64.70 \pm 0.34$ \\
\hline May (5) & $1.94 \pm 0.34$ & $9.70 \pm 1.04$ & $1017.33 \pm 0.79$ & $12.41 \pm 0.87$ & $50.21 \pm 0.39$ \\
\hline June (6) & $2.04 \pm 0.14$ & $9.53 \pm 0.72$ & $1016.55 \pm 1.26$ & $12.01 \pm 1.26$ & $26.79 \pm 0.34$ \\
\hline July (7) & $1.81 \pm 0.23$ & $8.78 \pm 0.52$ & $1016.94 \pm 0.75$ & $12.53 \pm 0.94$ & $11.99 \pm 0.05$ \\
\hline August (8) & $1.66 \pm 0.26$ & $9.01 \pm 1.27$ & $1016.59 \pm 0.86$ & $13.61 \pm 1.07$ & $25.92 \pm 0.15$ \\
\hline September (9) & $1.84 \pm 0.23$ & $9.63 \pm 1.01$ & $1015.31 \pm 1.24$ & $13.39 \pm 2.26$ & $44.69 \pm 0.32$ \\
\hline October (10) & $2.28 \pm 0.36$ & $11.23 \pm 0.73$ & $1016.98 \pm 0.49$ & $12.28 \pm 0.67$ & $45.17 \pm 0.26$ \\
\hline November (11) & $2.96 \pm 0.36$ & $12.38 \pm 0.59$ & $1017.83 \pm 3.76$ & $12.55 \pm 1.76$ & $56.49 \pm 0.12$ \\
\hline December (12) & $3.40 \pm 0.31$ & $13.37 \pm 0.59$ & $1018.31 \pm 0.78$ & $11.87 \pm 1.58$ & $72.07 \pm 0.21$ \\
\hline \multicolumn{6}{|c|}{ La Niña months } \\
\hline January (1) & $2.94 \pm 0.36$ & $13.01 \pm 1.01$ & $1020.75 \pm 2.25$ & $10.83 \pm 1.13$ & $55.88 \pm 0.12$ \\
\hline February (2) & $3.10 \pm 0.65$ & $12.45 \pm 1.14$ & $1018.82 \pm 3.38$ & $10.40 \pm 1.06$ & $62.96 \pm 0.24$ \\
\hline March (3) & $3.15 \pm 0.49$ & $12.73 \pm 1.49$ & $1018.06 \pm 1.79$ & $9.70 \pm 0.48$ & $59.08 \pm 0.27$ \\
\hline April (4) & $2.31 \pm 0.45$ & $10.60 \pm 0.31$ & $1018.52 \pm 0.82$ & $10.58 \pm 1.23$ & $32.32 \pm 0.21$ \\
\hline May (5) & $2.04 \pm 0.28$ & $10.12 \pm 0.21$ & $1019.01 \pm 1.09$ & $10.54 \pm 1.07$ & $19.23 \pm 0.04$ \\
\hline June (6) & $1.97 \pm 0.00$ & $9.56 \pm 0.00$ & $1017.98 \pm 0.00$ & $12.88 \pm 0.00$ & $19.64 \pm 0.00$ \\
\hline July (7) & $1.77 \pm 0.01$ & $8.47 \pm 0.71$ & $1017.56 \pm 0.44$ & $11.52 \pm 0.23$ & $12.96 \pm 0.06$ \\
\hline August (8) & $1.85 \pm 0.14$ & $8.68 \pm 0.64$ & $1015.33 \pm 0.64$ & $11.97 \pm 0.70$ & $41.83 \pm 0.50$ \\
\hline September (9) & $2.10 \pm 0.11$ & $9.74 \pm 0.43$ & $1014.41 \pm 1.81$ & $11.96 \pm 1.25$ & $45.82 \pm 0.37$ \\
\hline October (10) & $2.36 \pm 0.00$ & $11.65 \pm 0.00$ & $1017.81 \pm 0.55$ & $12.42 \pm 0.20$ & $58.11 \pm 0.37$ \\
\hline November (11) & $2.96 \pm 0.76$ & $13.30 \pm 0.01$ & $1018.34 \pm 2.26$ & $11.67 \pm 0.68$ & $76.39 \pm 0.18$ \\
\hline December (12) & $3.20 \pm 0.82$ & $12.73 \pm 1.34$ & $1021.43 \pm 2.44$ & $11.08 \pm 0.47$ & $59.98 \pm 0.23$ \\
\hline
\end{tabular}




\section{Appendix 9. Mean \pm 1 Standard Deviation Monthly Statistics of 0ceanographic and Meteorologic Parameters at the Point Arena Buoy (sta. 46014, fig. 1) for All Months and for El Niño and La Niña}

\section{Months}

\begin{tabular}{|c|c|c|c|c|c|}
\hline Month & $\begin{array}{c}\text { Significant wave } \\
\text { height } \\
(\mathrm{m})\end{array}$ & $\begin{array}{l}\text { Dominant wave } \\
\text { period } \\
\text { (sec) }\end{array}$ & $\begin{array}{c}\text { Sea-level barometric } \\
\text { pressure } \\
\text { (mbars) }\end{array}$ & $\begin{array}{c}\text { Sea-surface water } \\
\text { temperature } \\
\left({ }^{\circ} \mathrm{C}\right)\end{array}$ & $\begin{array}{l}\text { Frequency of winds } \\
\text { from the southwest } \\
\text { (pct) }\end{array}$ \\
\hline \multicolumn{6}{|c|}{ All months } \\
\hline January (1) & $2.86 \pm 0.46$ & $13.15 \pm 1.01$ & $1018.74 \pm 2.79$ & $11.94 \pm 0.52$ & $64.62 \pm 0.23$ \\
\hline February (2) & $2.95 \pm 0.44$ & $13.20 \pm 1.16$ & $1017.78 \pm 2.30$ & $11.77 \pm 0.43$ & $63.88 \pm 0.31$ \\
\hline March (3) & $2.80 \pm 0.22$ & $12.71 \pm 0.65$ & $1017.39 \pm 2.84$ & $11.33 \pm 0.70$ & $48.74 \pm 0.25$ \\
\hline April (4) & $2.35 \pm 0.29$ & $11.64 \pm 1.01$ & $1017.98 \pm 0.96$ & $10.96 \pm 0.68$ & $31.39 \pm 0.11$ \\
\hline May (5) & $2.16 \pm 0.16$ & $9.97 \pm 0.76$ & $1016.56 \pm 1.08$ & $11.06 \pm 0.63$ & $30.56 \pm 0.10$ \\
\hline June (6) & $2.11 \pm 0.26$ & $9.23 \pm 0.96$ & $1015.46 \pm 0.77$ & $11.24 \pm 0.72$ & $24.39 \pm 0.33$ \\
\hline July (7) & $1.96 \pm 0.21$ & $8.74 \pm 0.84$ & $1015.29 \pm 1.30$ & $12.36 \pm 3.29$ & $23.08 \pm 0.25$ \\
\hline August (8) & $1.75 \pm 0.13$ & $8.86 \pm 0.43$ & $1014.88 \pm 0.99$ & $12.85 \pm 1.82$ & $25.17 \pm 0.33$ \\
\hline September (9) & $1.91 \pm 0.15$ & $10.23 \pm 0.70$ & $1014.07 \pm 1.06$ & $13.41 \pm 0.96$ & $28.10 \pm 0.22$ \\
\hline October (10) & $2.22 \pm 0.25$ & $11.60 \pm 0.68$ & $1016.58 \pm 0.96$ & $13.05 \pm 1.15$ & $37.43 \pm 0.23$ \\
\hline November (11) & $2.74 \pm 0.41$ & $12.43 \pm 0.76$ & $1018.07 \pm 2.02$ & $12.85 \pm 1.07$ & $51.43 \pm 0.23$ \\
\hline December (12) & $3.08 \pm 0.41$ & $13.33 \pm 1.02$ & $1019.47 \pm 2.22$ & $12.47 \pm 0.85$ & $58.86 \pm 0.19$ \\
\hline \multicolumn{6}{|c|}{ El Niño months } \\
\hline January (1) & $3.33 \pm 0.28$ & $13.72 \pm 0.71$ & $1016.65 \pm 4.03$ & $12.51 \pm 1.17$ & $76.22 \pm 0.18$ \\
\hline February (2) & $3.80 \pm 0.67$ & $14.12 \pm 0.94$ & $1013.26 \pm 4.15$ & $12.99 \pm 0.99$ & $74.79 \pm 0.24$ \\
\hline March (3) & $2.81 \pm 0.05$ & $12.47 \pm 0.29$ & $1014.59 \pm 2.70$ & $12.37 \pm 1.00$ & $64.68 \pm 0.26$ \\
\hline April (4) & $2.57 \pm 0.14$ & $12.77 \pm 0.57$ & $1016.88 \pm 1.61$ & $11.73 \pm 0.72$ & $56.52 \pm 0.40$ \\
\hline May (5) & $1.86 \pm 0.31$ & $10.38 \pm 0.85$ & $1016.37 \pm 1.24$ & $12.52 \pm 0.85$ & $47.59 \pm 0.41$ \\
\hline June (6) & $2.19 \pm 0.08$ & $9.45 \pm 0.57$ & $1014.81 \pm 0.89$ & $11.75 \pm 0.98$ & $22.37 \pm 0.35$ \\
\hline July (7) & $1.95 \pm 0.20$ & $8.43 \pm 0.57$ & $1015.26 \pm 0.92$ & $12.25 \pm 0.81$ & $26.61 \pm 0.33$ \\
\hline August (8) & $1.61 \pm 0.26$ & $9.45 \pm 1.51$ & $1015.64 \pm 1.15$ & $13.59 \pm 1.01$ & $23.63 \pm 0.11$ \\
\hline September (9) & $1.87 \pm 0.22$ & $10.19 \pm 1.05$ & $1014.86 \pm 1.32$ & $13.77 \pm 0.99$ & $22.49 \pm 0.09$ \\
\hline October (10) & $2.11 \pm 0.35$ & $11.82 \pm 0.93$ & $1016.80 \pm 0.77$ & $13.60 \pm 1.06$ & $42.05 \pm 0.26$ \\
\hline November (11) & $2.77 \pm 0.31$ & $12.40 \pm 0.62$ & $1017.05 \pm 3.19$ & $13.78 \pm 1.82$ & $60.07 \pm 0.25$ \\
\hline December (12) & $3.39 \pm 0.33$ & $13.66 \pm 0.60$ & $1018.29 \pm 1.67$ & $12.88 \pm 1.13$ & $66.75 \pm 0.17$ \\
\hline \multicolumn{6}{|c|}{ La Niña months } \\
\hline January (1) & $2.80 \pm 0.52$ & $13.35 \pm 0.89$ & $1019.86 \pm 1.36$ & $11.64 \pm 0.97$ & $60.23 \pm 0.20$ \\
\hline February (2) & $2.97 \pm 0.54$ & $12.78 \pm 1.26$ & $1018.39 \pm 3.29$ & $11.20 \pm 1.16$ & $54.68 \pm 0.19$ \\
\hline March (3) & $3.02 \pm 0.48$ & $13.20 \pm 1.45$ & $1018.29 \pm 1.25$ & $10.31 \pm 0.39$ & $36.79 \pm 0.14$ \\
\hline April (4) & $2.27 \pm 0.64$ & $11.33 \pm 0.80$ & $1017.66 \pm 1.20$ & $11.84 \pm 0.00$ & $25.62 \pm 0.20$ \\
\hline May (5) & $2.09 \pm 0.57$ & $10.00 \pm 0.19$ & $1018.19 \pm 0.85$ & $10.65 \pm 0.00$ & $41.88 \pm 0.50$ \\
\hline June (6) & $2.08 \pm 0.00$ & $8.98 \pm 0.00$ & $1015.36 \pm 0.00$ & $11.49 \pm 0.00$ & $22.36 \pm 0.00$ \\
\hline July (7) & $1.85 \pm 0.04$ & $8.92 \pm 0.54$ & $1016.00 \pm 1.33$ & $11.13 \pm 0.00$ & $17.79 \pm 0.01$ \\
\hline August (8) & $1.73 \pm 0.17$ & $8.49 \pm 1.03$ & $1014.44 \pm 1.96$ & $12.17 \pm 0.78$ & $18.55 \pm 0.05$ \\
\hline September (9) & $2.04 \pm 0.19$ & $10.07 \pm 0.13$ & $1013.66 \pm 1.65$ & $12.85 \pm 0.43$ & $29.36 \pm 0.06$ \\
\hline October (10) & $2.29 \pm 0.01$ & $12.16 \pm 0.04$ & $1017.41 \pm 0.96$ & $12.52 \pm 0.77$ & $48.07 \pm 0.45$ \\
\hline November (11) & $2.90 \pm 0.35$ & $13.28 \pm 0.50$ & $1018.78 \pm 1.04$ & $12.33 \pm 0.44$ & $64.72 \pm 0.26$ \\
\hline December (12) & $2.93 \pm 0.49$ & $13.42 \pm 0.86$ & $1021.65 \pm 3.66$ & $11.86 \pm 0.35$ & $49.46 \pm 0.30$ \\
\hline
\end{tabular}


Appendix 10. Mean \pm 1 Standard Deviation Monthly Statistics of Oceanographic and Meteorologic Parameters at the Bodega Buoy (sta. 46013, fig. 1) for All Months and for El Niño and La Niña Months

\begin{tabular}{|c|c|c|c|c|c|}
\hline Month & $\begin{array}{l}\text { Significant wave } \\
\text { height } \\
\text { (m) }\end{array}$ & $\begin{array}{l}\text { Dominant wave } \\
\text { period } \\
\text { (sec) }\end{array}$ & $\begin{array}{c}\text { Sea-level barometric } \\
\text { pressure } \\
\text { (mbars) }\end{array}$ & $\begin{array}{c}\text { Sea-surface water } \\
\text { temperature } \\
\left({ }^{\circ} \mathrm{C}\right)\end{array}$ & $\begin{array}{l}\text { Frequency of winds } \\
\text { from the southwest } \\
\text { (pct) }\end{array}$ \\
\hline \multicolumn{6}{|c|}{ All months } \\
\hline January (1) & $2.63 \pm 0.34$ & $13.11 \pm 1.05$ & $1019.83 \pm 2.86$ & $11.81 \pm 0.63$ & $61.68 \pm 0.24$ \\
\hline February (2) & $2.63 \pm 0.39$ & $12.74 \pm 1.02$ & $1018.73 \pm 2.87$ & $11.69 \pm 0.76$ & $58.37 \pm 0.34$ \\
\hline March (3) & $2.68 \pm 0.25$ & $12.70 \pm 0.76$ & $1017.88 \pm 2.11$ & $11.38 \pm 0.95$ & $51.20 \pm 0.31$ \\
\hline April (4) & $2.38 \pm 0.30$ & $11.39 \pm 0.90$ & $1017.70 \pm 1.15$ & $10.78 \pm 0.95$ & $28.29 \pm 0.23$ \\
\hline May (5) & $2.21 \pm 0.09$ & $9.82 \pm 0.79$ & $1016.05 \pm 1.31$ & $10.32 \pm 0.58$ & $27.29 \pm 0.25$ \\
\hline June (6) & $2.10 \pm 0.34$ & $9.39 \pm 1.22$ & $1014.96 \pm 0.56$ & $10.23 \pm 0.81$ & $24.53 \pm 0.25$ \\
\hline July (7) & $1.81 \pm 0.21$ & $9.13 \pm 0.79$ & $1014.85 \pm 0.86$ & $11.20 \pm 0.83$ & $24.13 \pm 0.24$ \\
\hline Auqust (8) & $1.71 \pm 0.17$ & $8.76 \pm 0.93$ & $1014.79 \pm 0.83$ & $12.14 \pm 0.81$ & $27.25 \pm 0.25$ \\
\hline September (9) & $1.77 \pm 0.10$ & $10.42 \pm 0.87$ & $1014.20 \pm 1.34$ & $12.94 \pm 1.09$ & $29.42 \pm 0.23$ \\
\hline October (10) & $1.98 \pm 0.24$ & $11.51 \pm 0.73$ & $1016.42 \pm 1.11$ & $12.91 \pm 1.17$ & $26.93 \pm 0.08$ \\
\hline November (11) & $2.51 \pm 0.46$ & $12.40 \pm 0.85$ & $1018.88 \pm 1.43$ & $12.50 \pm 1.16$ & $41.68 \pm 0.16$ \\
\hline December (12) & $2.72 \pm 0.39$ & $13.21 \pm 1.08$ & $1020.08 \pm 1.87$ & $12.08 \pm 0.87$ & $54.89 \pm 0.19$ \\
\hline \multicolumn{6}{|c|}{ El Niño months } \\
\hline January (1) & $3.07 \pm 0.33$ & $13.77 \pm 0.77$ & $1017.85 \pm 3.37$ & $12.46 \pm 0.52$ & $77.87 \pm 0.20$ \\
\hline February (2) & $2.79 \pm 0.20$ & $12.63 \pm 0.63$ & $1016.54 \pm 2.03$ & $12.53 \pm 1.17$ & $76.76 \pm 0.29$ \\
\hline March (3) & $2.63 \pm 0.00$ & $12.67 \pm 0.00$ & $1017.60 \pm 0.00$ & $11.44 \pm 0.00$ & $85.85 \pm 0.28$ \\
\hline April (4) & $2.58 \pm 0.34$ & $12.12 \pm 1.49$ & $1017.28 \pm 1.72$ & $11.56 \pm 0.84$ & $41.85 \pm 0.36$ \\
\hline May (5) & $2.15 \pm 0.14$ & $10.29 \pm 1.47$ & $1015.79 \pm 1.37$ & $11.71 \pm 0.81$ & $50.32 \pm 0.41$ \\
\hline June (6) & $2.13 \pm 0.19$ & $9.54 \pm 0.96$ & $1014.73 \pm 1.15$ & $10.77 \pm 1.02$ & $37.44 \pm 0.43$ \\
\hline July (7) & $1.89 \pm 0.32$ & $8.90 \pm 0.55$ & $1014.84 \pm 1.18$ & $11.65 \pm 1.09$ & $26.49 \pm 0.34$ \\
\hline August (8) & $1.57 \pm 0.17$ & $9.04 \pm 1.57$ & $1015.70 \pm 1.52$ & $12.94 \pm 1.13$ & $33.22 \pm 0.34$ \\
\hline September (9) & $1.65 \pm 0.11$ & $9.76 \pm 0.61$ & $1015.24 \pm 1.13$ & $12.98 \pm 0.61$ & $34.13 \pm 0.37$ \\
\hline October (10) & $1.79 \pm 0.23$ & $11.75 \pm 0.92$ & $1016.52 \pm 1.27$ & $13.31 \pm 0.41$ & $36.63 \pm 0.28$ \\
\hline November (11) & $2.41 \pm 0.43$ & $12.10 \pm 0.93$ & $1018.86 \pm 2.30$ & $12.57 \pm 1.58$ & $58.33 \pm 0.41$ \\
\hline December (12) & $2.87 \pm 0.42$ & $13.56 \pm 0.65$ & $1018.80 \pm 1.48$ & $12.29 \pm 0.94$ & $68.47 \pm 0.24$ \\
\hline \multicolumn{6}{|c|}{ La Niña months } \\
\hline January (1) & $2.61 \pm 0.36$ & $13.17 \pm 0.78$ & $1020.98 \pm 1.56$ & $11.32 \pm 0.70$ & $45.48 \pm 0.11$ \\
\hline February (2) & $2.80 \pm 0.54$ & $12.77 \pm 1.11$ & $1019.22 \pm 2.95$ & $11.23 \pm 1.09$ & $46.33 \pm 0.21$ \\
\hline March (3) & $2.94 \pm 0.47$ & $13.07 \pm 1.41$ & $1018.02 \pm 0.89$ & $10.58 \pm 0.59$ & $33.15 \pm 0.13$ \\
\hline April (4) & $2.84 \pm 0.00$ & $10.56 \pm 0.00$ & $1017.24 \pm 0.03$ & $10.74 \pm 1.42$ & $23.32 \pm 0.16$ \\
\hline May (5) & $2.14 \pm 0.31$ & $9.13 \pm 0.87$ & $1016.72 \pm 0.74$ & $9.57 \pm 1.43$ & $10.18 \pm 0.05$ \\
\hline June (6) & $2.15 \pm 0.00$ & $9.89 \pm 0.00$ & $1015.27 \pm 0.00$ & $11.14 \pm 0.00$ & $22.22 \pm 0.00$ \\
\hline July (7) & $1.74 \pm 0.13$ & $9.47 \pm 0.54$ & $1015.19 \pm 0.38$ & $10.76 \pm 0.06$ & $19.94 \pm 0.05$ \\
\hline August (8) & $1.63 \pm 0.04$ & $8.60 \pm 1.27$ & $1014.10 \pm 1.24$ & $12.44 \pm 0.49$ & $48.03 \pm 0.45$ \\
\hline September (9) & $1.89 \pm 0.18$ & $10.50 \pm 0.33$ & $1013.55 \pm 1.66$ & $12.92 \pm 0.68$ & $28.71 \pm 0.06$ \\
\hline October (10) & $2.00 \pm 0.33$ & $11.92 \pm 1.08$ & $1017.17 \pm 0.68$ & $12.66 \pm 0.18$ & $23.15 \pm 0.05$ \\
\hline November (11) & $2.79 \pm 0.24$ & $13.17 \pm 0.14$ & $1019.49 \pm 0.56$ & $12.10 \pm 0.71$ & $43.35 \pm 0.07$ \\
\hline December (12) & $2.68 \pm 0.35$ & $13.14 \pm 1.04$ & $1021.58 \pm 3.22$ & $11.53 \pm 0.43$ & $35.27 \pm 0.13$ \\
\hline
\end{tabular}




\section{Appendix 11. Mean \pm 1 Standard Deviation Monthly Statistics of Oceanographic and Meteorologic Parameters at the San Francisco Buoy (sta. 46026, fig. 1) for All Months and for El Niño and La Niña Months}

[N.D., no data]

\begin{tabular}{|c|c|c|c|c|c|}
\hline Month & $\begin{array}{c}\text { Significant wave } \\
\text { height } \\
(\mathrm{m})\end{array}$ & $\begin{array}{l}\text { Dominant wave } \\
\text { period } \\
\text { (sec) }\end{array}$ & $\begin{array}{c}\text { Sea-level barometric } \\
\text { pressure } \\
\text { (mbars) }\end{array}$ & $\begin{array}{c}\text { Sea-surface water } \\
\text { temperature } \\
\left({ }^{\circ} \mathrm{C}\right)\end{array}$ & $\begin{array}{l}\text { Frequency of winds } \\
\text { from the southwest } \\
\text { (pct) }\end{array}$ \\
\hline \multicolumn{6}{|c|}{ All months } \\
\hline January (1) & $2.24 \pm 0.34$ & $13.41 \pm 0.92$ & $1019.45 \pm 2.60$ & $11.35 \pm 0.59$ & $60.42 \pm 0.27$ \\
\hline February (2) & $2.28 \pm 0.36$ & $13.43 \pm 0.68$ & $1018.05 \pm 2.46$ & $11.75 \pm 0.7$ & $53.53 \pm 0.24$ \\
\hline March (3) & $2.13 \pm 0.20$ & $12.68 \pm 0.87$ & $1017.74 \pm 2.21$ & $11.91 \pm 1.14$ & $47.36 \pm 0.29$ \\
\hline April (4) & $1.83 \pm 0.22$ & $11.60 \pm 0.75$ & $1017.58 \pm 0.97$ & $11.49 \pm 0.66$ & $34.14 \pm 0.22$ \\
\hline May (5) & $1.70 \pm 0.12$ & $10.39 \pm 0.53$ & $1016.01 \pm 1.04$ & $11.32 \pm 0.46$ & $30.56 \pm 0.25$ \\
\hline June (6) & $1.67 \pm 0.26$ & $9.90 \pm 1.21$ & $1014.70 \pm 0.69$ & $11.72 \pm 1.04$ & $34.01 \pm 0.25$ \\
\hline July (7) & $1.39 \pm 0.20$ & $9.64 \pm 0.82$ & $1015.13 \pm 1.05$ & $13.04 \pm 0.84$ & $38.36 \pm 0.30$ \\
\hline August (8) & $1.29 \pm 0.19$ & $9.44 \pm 0.55$ & $1014.80 \pm 1.23$ & $13.87 \pm 0.86$ & $39.40 \pm 0.36$ \\
\hline September (9) & $1.38 \pm 0.13$ & $10.90 \pm 1.04$ & $1013.70 \pm 0.95$ & $14.39 \pm 1.16$ & $46.72 \pm 0.33$ \\
\hline October (10) & $1.59 \pm 0.25$ & $11.72 \pm 0.70$ & $1016.24 \pm 1.07$ & $14.01 \pm 1.00$ & $37.98 \pm 0.22$ \\
\hline November (11) & $1.96 \pm 0.44$ & $12.35 \pm 0.73$ & $1018.66 \pm 1.34$ & $12.87 \pm 1.13$ & $41.04 \pm 0.25$ \\
\hline December (12) & $2.22 \pm 0.47$ & $13.47 \pm 0.99$ & $1020.16 \pm 2.19$ & $11.63 \pm 0.75$ & $52.49 \pm 0.31$ \\
\hline \multicolumn{6}{|c|}{ El Niño months } \\
\hline January (1) & $2.58 \pm 0.33$ & $13.80 \pm 0.94$ & $1017.47 \pm 2.84$ & $11.79 \pm 0.29$ & $64.47 \pm 0.29$ \\
\hline February (2) & $2.88 \pm 0.87$ & $13.49 \pm 1.11$ & $1014.75 \pm 2.59$ & $12.65 \pm 0.57$ & $55.73 \pm 0.15$ \\
\hline March (3) & $2.24 \pm 0.43$ & $12.76 \pm 0.44$ & $1015.01 \pm 2.17$ & $13.13 \pm 1.13$ & $62.54 \pm 0.26$ \\
\hline April (4) & $1.84 \pm 0.29$ & $11.90 \pm 1.91$ & $1017.42 \pm 1.56$ & $12.48 \pm 0.73$ & $40.05 \pm 0.34$ \\
\hline May (5) & $1.46 \pm 0.17$ & $10.55 \pm 1.47$ & $1015.49 \pm 1.16$ & $12.82 \pm 0.42$ & $41.24 \pm 0.33$ \\
\hline June (6) & $1.62 \pm 0.30$ & $9.89 \pm 0.89$ & $1014.06 \pm 1.31$ & $12.27 \pm 0.88$ & $38.17 \pm 0.31$ \\
\hline July (7) & $1.36 \pm 0.22$ & $9.33 \pm 1.52$ & $1015.00 \pm 1.08$ & $13.34 \pm 1.22$ & $38.44 \pm 0.32$ \\
\hline August (8) & $1.14 \pm 0.12$ & $9.43 \pm 1.83$ & $1015.55 \pm 1.11$ & $14.54 \pm 1.34$ & $36.69 \pm 0.31$ \\
\hline September (9) & $1.33 \pm 0.30$ & $10.61 \pm 0.55$ & $1014.04 \pm 1.62$ & $14.80 \pm 0.90$ & $41.70 \pm 0.34$ \\
\hline October (10) & $1.51 \pm 0.32$ & $11.85+1.32$ & $1016.27 \pm 1.41$ & $14.00 \pm 0.51$ & $37.96 \pm 0.28$ \\
\hline November (11) & $2.04 \pm 0.41$ & $12.07 \pm 1.27$ & $1017.24 \pm 2.96$ & $13.32 \pm 1.97$ & $53.74 \pm 0.36$ \\
\hline December (12) & $2.39 \pm 0.46$ & $13.50 \pm 0.89$ & $1018.87 \pm 1.02$ & $11.88 \pm 0.94$ & $54.20 \pm 0.24$ \\
\hline \multicolumn{6}{|c|}{ La Niña months } \\
\hline January (1) & $2.17 \pm 0.50$ & $13.51 \pm 0.85$ & $1021.36 \pm 1.52$ & $10.62 \pm 0.79$ & $64.36 \pm 0.29$ \\
\hline February (2) & $2.16 \pm 0.62$ & $12.96 \pm 0.63$ & $1018.99 \pm 3.14$ & $11.27 \pm 1.17$ & $69.63 \pm 0.32$ \\
\hline March (3) & $2.30 \pm 0.46$ & $12.77 \pm 1.34$ & $1018.21 \pm 0.92$ & $11.19 \pm 0.37$ & $47.10 \pm 0.32$ \\
\hline April (4) & $1.33 \pm 0.00$ & $12.48 \pm 0.00$ & $1017.06 \pm 0.00$ & $12.60 \pm 0.00$ & $69.37 \pm 0.43$ \\
\hline May (5) & $1.75 \pm 0.40$ & $10.35 \pm 0.87$ & $1016.81 \pm 0.52$ & $10.58 \pm 1.10$ & $18.07 \pm 0.02$ \\
\hline June (6) & N.D. & N.D. & N.D. & N.D. & N.D. \\
\hline July (7) & $1.41 \pm 0.20$ & $10.31 \pm 0.04$ & $1015.15 \pm 0.41$ & $12.69 \pm 0.13$ & $27.75 \pm 0.09$ \\
\hline August (8) & $1.22 \pm 0.03$ & $9.66 \pm 1.07$ & $1013.97 \pm 0.96$ & $13.91 \pm 0.80$ & $36.29 \pm 0.14$ \\
\hline September (9) & $1.48 \pm 0.28$ & $11.14 \pm 0.35$ & $1013.36 \pm 2.13$ & $14.09 \pm 0.53$ & $55.07 \pm 0.31$ \\
\hline October (10) & $1.75 \pm 0.22$ & $12.40 \pm 0.30$ & $1016.77 \pm 0.52$ & $13.72 \pm 0.54$ & $49.62 \pm 0.44$ \\
\hline November (11) & $2.21 \pm 0.15$ & $13.07 \pm 0.35$ & $1019.43 \pm 0.48$ & $12.48 \pm 0.51$ & $43.08 \pm 0.10$ \\
\hline December (12) & $2.20 \pm 0.24$ & $13.66 \pm 0.57$ & $1022.55 \pm 1.73$ & $11.28 \pm 0.14$ & $45.49 \pm 0.34$ \\
\hline
\end{tabular}


Appendix 12. Mean \pm 1 Standard Deviation Monthly Statistics of Oceanographic and Meteorologic Parameters at the Half Moon Bay Buoy (sta. 46012, fig. 1) for All Months and for El Niño and La Niña Months

\begin{tabular}{|c|c|c|c|c|c|}
\hline Month & $\begin{array}{c}\text { Significant wave } \\
\text { height } \\
(\mathrm{m})\end{array}$ & $\begin{array}{l}\text { Dominant wave } \\
\text { period } \\
\text { (sec) }\end{array}$ & $\begin{array}{c}\text { Sea-level barometric } \\
\text { pressure } \\
\text { (mbars) }\end{array}$ & $\begin{array}{c}\text { Sea-surface water } \\
\text { temperature } \\
\left({ }^{\circ} \mathrm{C}\right)\end{array}$ & $\begin{array}{l}\text { Frequency of winds } \\
\text { from the southwest } \\
\text { (pct) }\end{array}$ \\
\hline \multicolumn{6}{|c|}{ All months } \\
\hline January (1) & $2.38 \pm 0.31$ & $12.80 \pm 1.12$ & $1019.78 \pm 2.53$ & $12.27 \pm 0.63$ & $48.12 \pm 0.23$ \\
\hline February (2) & $2.57 \pm 0.37$ & $12.72 \pm 0.89$ & $1018.58 \pm 2.05$ & $12.17 \pm 0.88$ & $58.27 \pm 0.38$ \\
\hline March (3) & $2.51 \pm 0.27$ & $12.46 \pm 0.37$ & $1017.36 \pm 2.38$ & $12.37 \pm 0.87$ & $61.00 \pm 0.39$ \\
\hline April (4) & $2.14 \pm 0.22$ & $11.15 \pm 0.83$ & $1017.50 \pm 0.66$ & $11.85 \pm 0.65$ & $52.17 \pm 0.43$ \\
\hline May (5) & $2.02 \pm 0.49$ & $10.25 \pm 0.84$ & $1016.34 \pm 1.24$ & $12.25 \pm 0.64$ & $50.92 \pm 0.42$ \\
\hline June (6) & $1.83 \pm 0.23$ & $9.58 \pm 1.18$ & $1015.04 \pm 0.83$ & $12.69 \pm 0.71$ & $53.28 \pm 0.41$ \\
\hline July (7) & $1.63 \pm 0.18$ & $9.72 \pm 1.07$ & $1015.31 \pm 1.40$ & $13.84 \pm 0.61$ & $51.87 \pm 0.40$ \\
\hline August (8) & $1.49 \pm 0.14$ & $9.52 \pm 0.52$ & $1016.47 \pm 1.30$ & $14.56 \pm 0.63$ & $39.30 \pm 0.32$ \\
\hline September (9) & $1.58 \pm 0.12$ & $10.77 \pm 0.98$ & $1014.73 \pm 1.23$ & $14.60 \pm 1.12$ & $36.34 \pm 0.22$ \\
\hline October (10) & $1.87 \pm 0.20$ & $11.44 \pm 0.75$ & $1016.89 \pm 1.19$ & $14.18 \pm 1.13$ & $36.23 \pm 0.22$ \\
\hline November (11) & $2.31 \pm 0.42$ & $12.22 \pm 0.71$ & $1018.72 \pm 1.25$ & $13.17 \pm 1.16$ & $39.03 \pm 0.31$ \\
\hline December (12) & $2.47 \pm 0.38$ & $12.85 \pm 1.11$ & $1019.91 \pm 1.68$ & $12.61 \pm 0.73$ & $42.80 \pm 0.14$ \\
\hline \multicolumn{6}{|c|}{ El Niño months } \\
\hline January (1) & $2.59 \pm 0.16$ & $13.23 \pm 0.68$ & $1019.60 \pm 1.57$ & $12.70 \pm 1.06$ & $69.78 \pm 0.34$ \\
\hline February (2) & $3.13 \pm 0.82$ & $12.80 \pm 1.30$ & $1015.73 \pm 0.39$ & $13.69 \pm 0.32$ & $80.88 \pm 0.22$ \\
\hline March (3) & $2.74 \pm 0.64$ & $12.66 \pm 0.29$ & $1013.89 \pm 0.96$ & $13.88 \pm 0.24$ & $77.50 \pm 0.27$ \\
\hline April (4) & $2.08 \pm 0.08$ & $10.51 \pm 1.18$ & $1016.45 \pm 1.65$ & $13.45 \pm 0.89$ & $71.51 \pm 0.39$ \\
\hline May (5) & $1.67 \pm 0.22$ & $10.27 \pm 1.56$ & $1015.89 \pm 1.37$ & $13.43 \pm 0.44$ & $59.52 \pm 0.45$ \\
\hline June (6) & $1.97 \pm 0.33$ & $9.52 \pm 0.66$ & $1013.78 \pm 1.29$ & $13.30 \pm 0.62$ & $67.76 \pm 0.41$ \\
\hline July (7) & $1.87 \pm 0.58$ & $9.36 \pm 0.83$ & $1015.67 \pm 0.69$ & $14.51 \pm 0.61$ & $47.74 \pm 0.49$ \\
\hline August (8) & $1.52 \pm 0.31$ & $9.37 \pm 1.84$ & $1022.06 \pm 12.25$ & $15.95 \pm 1.66$ & $50.42 \pm 0.41$ \\
\hline September (9) & $1.71 \pm 0.54$ & $10.30 \pm 0.68$ & $1019.04 \pm 6.40$ & $14.72 \pm 0.55$ & $54.51 \pm 0.42$ \\
\hline October (10) & $1.89 \pm 0.40$ & $11.67 \pm 0.82$ & $1018.51 \pm 6.50$ & $14.53 \pm 0.79$ & $45.95 \pm 0.37$ \\
\hline November (11) & $2.36 \pm 0.16$ & $12.16 \pm 0.67$ & $1018.76 \pm 2.06$ & $13.27 \pm 1.41$ & $40.46 \pm 0.35$ \\
\hline December (12) & $2.70 \pm 0.31$ & $13.14 \pm 0.81$ & $1019.08 \pm 0.91$ & $12.98 \pm 0.85$ & $60.50 \pm 0.31$ \\
\hline \multicolumn{6}{|c|}{ La Niña months } \\
\hline January (1) & $2.38 \pm 0.34$ & $13.09 \pm 0.91$ & $1020.57 \pm 2.00$ & $11.56 \pm 0.68$ & $29.68 \pm 0.14$ \\
\hline February (2) & $2.54 \pm 0.55$ & $12.42 \pm 0.98$ & $1018.57 \pm 3.21$ & $11.59 \pm 0.78$ & $51.30 \pm 0.32$ \\
\hline March (3) & $2.50 \pm 0.38$ & $12.47 \pm 1.30$ & $1018.23 \pm 1.62$ & $11.29 \pm 0.55$ & $57.71 \pm 0.34$ \\
\hline April (4) & $1.95 \pm 0.50$ & $11.60 \pm 1.17$ & $1017.37 \pm 0.93$ & $11.44 \pm 2.07$ & $26.50 \pm 0.14$ \\
\hline May (5) & $1.79 \pm 0.28$ & $10.50 \pm 0.74$ & $1017.65 \pm 1.37$ & $12.29 \pm 0.23$ & $40.16 \pm 0.52$ \\
\hline June (6) & $1.96 \pm 0.00$ & $10.28 \pm 0.00$ & $1016.02 \pm 0.00$ & $12.43 \pm 0.00$ & $26.09 \pm 0.00$ \\
\hline July (7) & $1.51 \pm 0.00$ & $9.64 \pm 0.00$ & $1015.69 \pm 0.00$ & $13.53 \pm 0.00$ & $62.53 \pm 0.53$ \\
\hline August (8) & $1.42 \pm 0.05$ & $9.55 \pm 0.44$ & $1014.38 \pm 1.08$ & $14.31 \pm 0.78$ & $56.25 \pm 0.38$ \\
\hline September (9) & $1.62 \pm 0.20$ & $11.01 \pm 0.40$ & $1013.43 \pm 1.95$ & $14.49 \pm 0.64$ & $29.31 \pm 0.11$ \\
\hline October (10) & $1.76 \pm 0.39$ & $11.80 \pm 0.70$ & $1016.79 \pm 1.05$ & $13.86 \pm 0.31$ & $27.80 \pm 0.10$ \\
\hline November (11) & $2.44 \pm 0.21$ & $12.92 \pm 0.16$ & $1019.45 \pm 1.04$ & $12.69 \pm 0.54$ & $32.38 \pm 0.10$ \\
\hline December (12) & $2.36 \pm 0.26$ & $13.06 \pm 0.93$ & $1021.21 \pm 2.84$ & $11.95 \pm 0.52$ & $28.72 \pm 0.10$ \\
\hline
\end{tabular}


Appendix 13. Mean \pm 1 Standard Deviation Monthly Statistics of Oceanographic and Meteorologic Parameters at the Monterey Bay Buoy (sta. 46042, fig. 1) for All Months and for El Niño and La Niña Months

[N.D., no data]

\begin{tabular}{|c|c|c|c|c|c|}
\hline Month & $\begin{array}{c}\text { Significant wave } \\
\text { height } \\
(\mathrm{m})\end{array}$ & $\begin{array}{l}\text { Dominant wave } \\
\text { period } \\
\text { (sec) }\end{array}$ & $\begin{array}{c}\text { Sea-level barometric } \\
\text { pressure } \\
\text { (mbars) }\end{array}$ & $\begin{array}{c}\text { Sea-surface water } \\
\text { temperature } \\
\left({ }^{\circ} \mathrm{C}\right)\end{array}$ & $\begin{array}{l}\text { Frequency of winds } \\
\text { from the southwest } \\
\text { (pct) }\end{array}$ \\
\hline \multicolumn{6}{|c|}{ All months } \\
\hline January (1) & $2.66 \pm 0.43$ & $13.08 \pm 1.02$ & $1019.34 \pm 2.80$ & $12.24 \pm 0.48$ & $52.97 \pm 0.08$ \\
\hline February (2) & $2.67 \pm 0.37$ & $13.07 \pm 0.42$ & $1018.44 \pm 2.39$ & $12.00 \pm 0.59$ & $51.43 \pm 0.15$ \\
\hline March (3) & $2.65 \pm 0.27$ & $13.04 \pm 0.58$ & $1017.95 \pm 2.14$ & $11.90 \pm 0.94$ & $40.69 \pm 0.15$ \\
\hline April (4) & $2.24 \pm 0.19$ & $11.84 \pm 0.56$ & $1018.08 \pm 1.12$ & $12.11 \pm 0.42$ & $34.05 \pm 0.08$ \\
\hline May (5) & $2.09 \pm 0.10$ & $10.92 \pm 0.39$ & $1016.39 \pm 0.94$ & $12.06 \pm 0.65$ & $34.12 \pm 0.19$ \\
\hline June (6) & $2.01 \pm 0.16$ & $10.02 \pm 1.03$ & $1015.21 \pm 0.82$ & $12.50 \pm 0.89$ & $31.07 \pm 0.32$ \\
\hline July (7) & $1.70 \pm 0.21$ & $9.73 \pm 0.85$ & $1015.27 \pm 1.13$ & $13.48 \pm 0.72$ & $21.84 \pm 0.06$ \\
\hline August (8) & $1.64 \pm 0.14$ & $9.79 \pm 0.37$ & $1014.98 \pm 1.26$ & $14.34 \pm 1.13$ & $18.92 \pm 0.09$ \\
\hline September (9) & $1.75 \pm 0.14$ & $11.02 \pm 0.55$ & $1014.11 \pm 0.83$ & $14.83 \pm 0.85$ & $24.70 \pm 0.05$ \\
\hline October (10) & $2.09 \pm 0.19$ & $11.67 \pm 0.50$ & $1016.04 \pm 1.18$ & $14.61 \pm 0.69$ & $27.07 \pm 0.08$ \\
\hline November (11) & $2.45 \pm 0.31$ & $12.46 \pm 0.73$ & $1019.31 \pm 0.85$ & $12.96 \pm 0.63$ & $34.03 \pm 0.11$ \\
\hline December (12) & $2.77 \pm 0.43$ & $13.22 \pm 0.79$ & $1020.16 \pm 1.50$ & $12.39 \pm 0.82$ & $40.39 \pm 0.11$ \\
\hline \multicolumn{6}{|c|}{ El Niño months } \\
\hline January (1) & $3.03 \pm 0.35$ & $13.52 \pm 0.44$ & $1017.97 \pm 3.19$ & $12.26 \pm 0.44$ & $69.79 \pm 0.33$ \\
\hline February (2) & $2.52 \pm 0.00$ & $12.23 \pm 0.00$ & $1015.57 \pm 0.00$ & N.D. & $86.98 \pm 0.23$ \\
\hline March (3) & $2.30 \pm 0.00$ & $13.26 \pm 0.00$ & $1014.56 \pm 0.00$ & N.D. & $82.63 \pm 0.30$ \\
\hline April (4) & $2.42 \pm 0.58$ & $12.27 \pm 1.30$ & $1018.46 \pm 1.46$ & N.D. & $56.07 \pm 0.51$ \\
\hline May (5) & $1.85 \pm 0.26$ & $11.30 \pm 0.63$ & $1015.50 \pm 0.61$ & $13.19 \pm 0.00$ & $55.11 \pm 0.43$ \\
\hline June (6) & $2.07 \pm 0.23$ & $9.93 \pm 0.33$ & $1014.29 \pm 0.83$ & $12.68 \pm 1.48$ & $42.57 \pm 0.46$ \\
\hline July (7) & $1.76 \pm 0.26$ & $9.67 \pm 0.70$ & $1014.94 \pm 0.77$ & $13.62 \pm 0.14$ & $21.03 \pm 0.16$ \\
\hline August (8) & $1.54 \pm 0.16$ & $10.40 \pm 1.31$ & $1015.43 \pm 0.83$ & $15.59 \pm 0.71$ & $41.81 \pm 0.51$ \\
\hline September (9) & $1.80 \pm 0.31$ & $10.49 \pm 0.68$ & $1014.06 \pm 1.91$ & $17.12 \pm 0.00$ & $56.59 \pm 0.61$ \\
\hline October (10) & $2.09 \pm 0.44$ & $11.55 \pm 0.88$ & $1015.48 \pm 0.99$ & $15.36 \pm 0.78$ & $40.47 \pm 0.40$ \\
\hline November (11) & $2.72 \pm 0.03$ & $12.44 \pm 0.56$ & $1019.56 \pm 0.40$ & $12.48 \pm 0.00$ & $58.99 \pm 0.48$ \\
\hline December (12) & $3.09 \pm 0.34$ & $13.27 \pm 0.27$ & $1018.38 \pm 0.79$ & $12.62 \pm 0.36$ & $55.20 \pm 0.31$ \\
\hline \multicolumn{6}{|c|}{ La Niña months } \\
\hline January (1) & $2.65 \pm 0.52$ & $13.00 \pm 0.89$ & $1020.21 \pm 1.06$ & $11.97 \pm 0.61$ & $49.60 \pm 0.29$ \\
\hline February (2) & $3.04 \pm 0.33$ & $13.36 \pm 0.64$ & $1018.09 \pm 2.77$ & $11.91 \pm 0.87$ & $61.36 \pm 0.24$ \\
\hline March (3) & $3.07 \pm 0.26$ & $13.58 \pm 0.77$ & $1017.76 \pm 0.77$ & $11.56 \pm 0.21$ & $44.19 \pm 0.38$ \\
\hline April (4) & $1.71 \pm 0.00$ & $12.18 \pm 0.00$ & $1018.09 \pm 0.00$ & $12.84 \pm 0.00$ & $62.48 \pm 0.53$ \\
\hline May (5) & $2.18 \pm 0.00$ & $11.00 \pm 0.00$ & $1018.81 \pm 0.00$ & $12.54 \pm 0.00$ & $52.44 \pm 0.67$ \\
\hline June (6) & $2.07 \pm 0.00$ & $10.39 \pm 0.00$ & $1015.28 \pm 0.00$ & $12.59 \pm 0.00$ & $18.25 \pm 0.00$ \\
\hline July (7) & $1.62 \pm 0.00$ & $9.84 \pm 0.00$ & $1014.95 \pm 0.00$ & $13.19 \pm 0.00$ & $59.92 \pm 0.57$ \\
\hline August (8) & $1.54 \pm 0.16$ & $9.68 \pm 0.22$ & $1014.40 \pm 1.35$ & $14.56 \pm 0.38$ & $19.76 \pm 0.06$ \\
\hline September (9) & $1.86 \pm 0.06$ & $10.82 \pm 0.64$ & $1012.78 \pm 1.14$ & $14.57 \pm 1.04$ & $24.25 \pm 0.10$ \\
\hline October (10) & $1.88 \pm 0.33$ & $11.86 \pm 0.96$ & $1016.52 \pm 0.57$ & $14.11 \pm 0.42$ & $17.40 \pm 0.06$ \\
\hline November (11) & $2.67 \pm 0.31$ & $13.16 \pm 0.33$ & $1019.49 \pm 0.51$ & $12.77 \pm 0.49$ & $28.80 \pm 0.14$ \\
\hline December (12) & $2.64 \pm 0.29$ & $13.51 \pm 0.69$ & $1022.20 \pm 1.66$ & $11.84 \pm 0.46$ & $19.88 \pm 0.08$ \\
\hline
\end{tabular}


Appendix 14. Mean \pm 1 Standard Deviation Monthly Statistics of Oceanographic and Meteorologic Parameters at the Cape San Martin Buoy (sta. 46028, fig. 1) for All Months and for El Niño and La Niña Months

\begin{tabular}{|c|c|c|c|c|c|}
\hline Month & $\begin{array}{c}\text { Significant wave } \\
\text { height } \\
(\mathrm{m})\end{array}$ & $\begin{array}{c}\text { Dominant wave } \\
\text { period } \\
\text { (sec) }\end{array}$ & $\begin{array}{c}\text { Sea-level barometric } \\
\text { pressure } \\
\text { (mbars) }\end{array}$ & $\begin{array}{c}\text { Sea-surface water } \\
\text { temperature } \\
\left({ }^{\circ} \mathrm{C}\right) \\
\end{array}$ & $\begin{array}{l}\text { Frequency of winds } \\
\text { from the southwest } \\
\text { (pct) }\end{array}$ \\
\hline \multicolumn{6}{|c|}{ All months } \\
\hline January (1) & $2.59 \pm 0.45$ & $13.27 \pm 1.40$ & $1020.28 \pm 2.33$ & $12.86 \pm 0.65$ & $51.07 \pm 0.27$ \\
\hline February (2) & $2.68 \pm 0.60$ & $13.46 \pm 0.69$ & $1019.27 \pm 2.26$ & $12.57 \pm 0.67$ & $50.00 \pm 0.28$ \\
\hline March (3) & $2.67 \pm 0.18$ & $12.65 \pm 0.49$ & $1018.30 \pm 1.20$ & $12.60 \pm 0.75$ & $53.08 \pm 0.39$ \\
\hline April (4) & $2.40 \pm 0.32$ & $11.75 \pm 0.84$ & $1017.44 \pm 1.00$ & $12.10 \pm 0.81$ & $30.79 \pm 0.25$ \\
\hline May (5) & $2.32 \pm 0.15$ & $10.24 \pm 0.49$ & $1015.98 \pm 1.07$ & $12.29 \pm 0.74$ & $25.08 \pm 0.07$ \\
\hline June (6) & $2.23 \pm 0.20$ & $9.77 \pm 1.18$ & $1014.69 \pm 0.80$ & $12.86 \pm 0.81$ & $29.65 \pm 0.08$ \\
\hline July (7) & $1.90 \pm 0.22$ & $9.53 \pm 0.83$ & $1015.01 \pm 0.87$ & $14.05 \pm 0.77$ & $20.30 \pm 0.27$ \\
\hline August (8) & $1.85 \pm 0.16$ & $9.32 \pm 0.38$ & $1014.71 \pm 0.93$ & $15.17 \pm 0.92$ & $32.43 \pm 0.27$ \\
\hline September (9) & $1.84 \pm 0.12$ & $10.60 \pm 0.91$ & $1014.00 \pm 1.22$ & $15.50 \pm 1.06$ & $30.03 \pm 0.35$ \\
\hline October (10) & $2.11 \pm 0.19$ & $11.81 \pm 0.62$ & $1015.91 \pm 1.13$ & $15.10 \pm 0.49$ & $28.18 \pm 0.26$ \\
\hline November (11) & $2.49 \pm 0.28$ & $12.69 \pm 0.87$ & $1018.81 \pm 0.94$ & $14.05 \pm 0.62$ & $31.35 \pm 0.25$ \\
\hline December (12) & $2.88 \pm 0.44$ & $13.51 \pm 1.09$ & $1019.81 \pm 1.11$ & $13.52 \pm 0.76$ & $42.24 \pm 0.12$ \\
\hline \multicolumn{6}{|c|}{ El Niño months } \\
\hline January (1) & $2.78 \pm 0.48$ & $14.78 \pm 0.76$ & $1021.08 \pm 0.20$ & $13.13 \pm 0.69$ & $76.70 \pm 0.36$ \\
\hline February (2) & $3.06 \pm 0.00$ & $13.29 \pm 0.00$ & $1017.98 \pm 0.00$ & $13.32 \pm 0.00$ & $83.17 \pm 0.34$ \\
\hline March (3) & $2.64 \pm 0.00$ & $12.87 \pm 0.00$ & $1018.30 \pm 0.00$ & $12.94 \pm 0.00$ & $83.09 \pm 0.34$ \\
\hline April (4) & $2.46 \pm 0.00$ & $13.19 \pm 0.00$ & $1018.03 \pm 0.40$ & $11.93 \pm 0.00$ & $62.34 \pm 0.52$ \\
\hline May (5) & $2.00 \pm 0.30$ & $10.61 \pm 0.23$ & $1015.26 \pm 0.75$ & $12.70 \pm 0.97$ & $58.69 \pm 0.46$ \\
\hline June (6) & $2.35 \pm 0.20$ & $9.89 \pm 0.51$ & $1014.67 \pm 2.04$ & $12.94 \pm 0.74$ & $64.07 \pm 0.45$ \\
\hline July (7) & $1.99 \pm 0.20$ & $9.46 \pm 0.71$ & $1014.67 \pm 0.78$ & $14.63 \pm 1.35$ & $28.94 \pm 0.36$ \\
\hline August (8) & $1.79 \pm 0.12$ & $9.80 \pm 1.32$ & $1015.62 \pm 1.35$ & $16.20 \pm 1.47$ & $48.20 \pm 0.47$ \\
\hline September (9) & $1.75 \pm 0.22$ & $9.94 \pm 0.55$ & $1015.57 \pm 0.73$ & $16.31 \pm 1.53$ & $33.13 \pm 0.45$ \\
\hline October (10) & $1.88 \pm 0.34$ & $12.11 \pm 0.95$ & $1016.03 \pm 0.89$ & $16.41 \pm 1.23$ & $30.44 \pm 0.34$ \\
\hline November (11) & $2.56 \pm 0.32$ & $13.01 \pm 0.51$ & $1019.39 \pm 0.06$ & $15.04 \pm 1.34$ & $39.35 \pm 0.41$ \\
\hline December (12) & $3.10 \pm 0.27$ & $14.18 \pm 0.60$ & $1019.53 \pm 0.39$ & $14.36 \pm 0.61$ & $57.47 \pm 0.35$ \\
\hline \multicolumn{6}{|c|}{ La Niña months } \\
\hline January (1) & $2.65 \pm 0.38$ & $13.80 \pm 0.80$ & $1020.52 \pm 1.45$ & $12.46 \pm 0.84$ & $39.87 \pm 0.31$ \\
\hline February (2) & $2.77 \pm 0.45$ & $13.29 \pm 0.91$ & $1019.72 \pm 2.67$ & $12.29 \pm 1.07$ & $52.22 \pm 0.35$ \\
\hline March (3) & $2.83 \pm 0.61$ & $12.90 \pm 1.91$ & $1017.40 \pm 1.63$ & $11.99 \pm 0.26$ & $55.31 \pm 0.41$ \\
\hline April (4) & $2.38 \pm 0.69$ & $11.70 \pm 0.84$ & $1016.66 \pm 0.18$ & $12.34 \pm 0.92$ & $17.11 \pm 0.02$ \\
\hline May (5) & $2.36 \pm 0.38$ & $9.95 \pm 0.46$ & $1016.62 \pm 0.75$ & $12.36 \pm 1.16$ & $9.10 \pm 0.03$ \\
\hline June (6) & $2.03 \pm 0.00$ & $10.09 \pm 0.00$ & $1015.61 \pm 0.00$ & $14.25 \pm 0.00$ & $12.80 \pm 0.00$ \\
\hline July (7) & $1.77 \pm 0.32$ & $10.00 \pm 0.62$ & $1015.25 \pm 0.10$ & $13.55 \pm 0.21$ & $12.10 \pm 0.12$ \\
\hline August (8) & $1.55 \pm 0.00$ & $9.46 \pm 0.00$ & $1013.29 \pm 0.00$ & $16.08 \pm 0.00$ & $73.05 \pm 0.47$ \\
\hline September (9) & $1.82 \pm 0.15$ & $10.59 \pm 0.57$ & $1013.19 \pm 1.90$ & $15.71 \pm 0.45$ & $39.15 \pm 0.41$ \\
\hline October (10) & $1.88 \pm 0.61$ & $11.34 \pm 1.51$ & $1015.85 \pm 1.09$ & $14.49 \pm 0.07$ & $42.37 \pm 0.50$ \\
\hline November (11) & $2.81 \pm 0.19$ & $13.78 \pm 0.01$ & $1018.84 \pm 0.88$ & $13.41 \pm 0.40$ & $36.59 \pm 0.43$ \\
\hline December (12) & $3.01 \pm 0.51$ & $13.19 \pm 1.23$ & $1020.01 \pm 2.30$ & $12.87 \pm 0.50$ & $40.51 \pm 0.35$ \\
\hline
\end{tabular}




\section{Appendix 15. Mean \pm 1 Standard Deviation Monthly Statistics of Oceanographic and Meteorologic Parameters at the Point Arguello Buoy (sta. 46023, fig. 1) for All Months and for El Niño and La Niña Months}

\begin{tabular}{|c|c|c|c|c|c|}
\hline Month & $\begin{array}{c}\text { Significant wave } \\
\text { height } \\
(\mathrm{m})\end{array}$ & $\begin{array}{l}\text { Dominant wave } \\
\text { period } \\
\text { (sec) }\end{array}$ & $\begin{array}{c}\text { Sea-level barometric } \\
\text { pressure } \\
\text { (mbars) }\end{array}$ & $\begin{array}{c}\text { Sea-surface water } \\
\text { temperature } \\
\left({ }^{\circ} \mathrm{C}\right)\end{array}$ & $\begin{array}{l}\text { Frequency of winds } \\
\text { from the southwest } \\
\text { (pct) }\end{array}$ \\
\hline \multicolumn{6}{|c|}{ All months } \\
\hline January (1) & $2.56 \pm 0.32$ & $13.79 \pm 1.03$ & $1018.88 \pm 2.22$ & $13.62 \pm 0.72$ & $38.40 \pm 0.42$ \\
\hline February (2) & $2.67 \pm 0.37$ & $13.61 \pm 0.71$ & $1018.00 \pm 2.02$ & $13.32 \pm 0.63$ & $41.48 \pm 0.39$ \\
\hline March (3) & $2.65 \pm 0.31$ & $13.22 \pm 0.69$ & $1016.98 \pm 1.47$ & $13.20 \pm 0.66$ & $35.28 \pm 0.42$ \\
\hline April (4) & $2.39 \pm 0.42$ & $11.92 \pm 1.22$ & $1016.44 \pm 0.93$ & $12.59 \pm 0.52$ & $29.32 \pm 0.41$ \\
\hline May (5) & $2.19 \pm 0.19$ & $10.43 \pm 0.74$ & $1015.34 \pm 0.92$ & $12.57 \pm 0.91$ & $29.89 \pm 0.46$ \\
\hline June (6) & $2.05 \pm 0.23$ & $10.21 \pm 1.03$ & $1014.02 \pm 0.73$ & $13.48 \pm 0.70$ & $16.55 \pm 0.35$ \\
\hline July (7) & $1.75 \pm 0.20$ & $9.68 \pm 0.72$ & $1014.53 \pm 1.01$ & $15.04 \pm 0.69$ & $11.50 \pm 0.29$ \\
\hline August (8) & $1.68 \pm 0.17$ & $9.50 \pm 0.76$ & $1014.28 \pm 1.16$ & $15.56 \pm 1.33$ & $9.29 \pm 0.29$ \\
\hline September (9) & $1.75 \pm 0.09$ & $10.92 \pm 1.08$ & $1013.21 \pm 0.86$ & $16.07 \pm 1.57$ & $13.90 \pm 0.28$ \\
\hline October (10) & $2.00 \pm 0.21$ & $11.80 \pm 0.65$ & $1015.34 \pm 1.02$ & $15.99 \pm 1.06$ & $19.70 \pm 0.29$ \\
\hline November (11) & $2.40 \pm 0.53$ & $12.68 \pm 1.12$ & $1017.64 \pm 0.65$ & $15.31 \pm 0.64$ & $38.14 \pm 0.40$ \\
\hline December (12) & $2.61 \pm 0.47$ & $13.76 \pm 0.88$ & $1019.54 \pm 1.20$ & $14.12 \pm 0.77$ & $43.75 \pm 0.38$ \\
\hline \multicolumn{6}{|c|}{ El Niño months } \\
\hline January (1) & $2.93 \pm 0.16$ & $14.40 \pm 0.91$ & $1017.26 \pm 1.17$ & $14.43 \pm 1.07$ & $39.66 \pm 0.35$ \\
\hline February (2) & $3.26 \pm 0.86$ & $14.17 \pm 1.04$ & $1015.38 \pm 0.93$ & $14.53 \pm 0.86$ & $38.14 \pm 0.08$ \\
\hline March (3) & $2.68 \pm 0.41$ & $13.47 \pm 0.30$ & $1015.11 \pm 1.46$ & $14.18 \pm 0.92$ & $25.29 \pm 0.14$ \\
\hline April (4) & $2.52 \pm 0.43$ & $12.25 \pm 1.26$ & $1015.85 \pm 1.04$ & $13.17 \pm 0.77$ & $11.63 \pm 0.10$ \\
\hline May (5) & $2.02 \pm 0.17$ & $10.83 \pm 1.34$ & $1014.76 \pm 1.06$ & $13.80 \pm 0.58$ & $26.51 \pm 0.37$ \\
\hline June (6) & $2.08 \pm 0.30$ & $10.34 \pm 1.04$ & $1013.56 \pm 1.40$ & $14.06 \pm 0.83$ & $7.27 \pm 0.04$ \\
\hline July (7) & $1.82 \pm 0.24$ & $9.51 \pm 0.97$ & $1013.99 \pm 0.68$ & $15.39 \pm 1.05$ & $7.46 \pm 0.06$ \\
\hline August (8) & $1.67 \pm 0.13$ & $9.49 \pm 2.05$ & $1014.53 \pm 0.57$ & $16.30 \pm 1.17$ & $5.75 \pm 0.05$ \\
\hline September (9) & $1.82 \pm 0.26$ & $10.40 \pm 1.00$ & $1013.47 \pm 1.49$ & $16.49 \pm 1.36$ & $8.45 \pm 0.09$ \\
\hline October (10) & $2.00 \pm 0.22$ & $11.98 \pm 1.12$ & $1015.05 \pm 0.93$ & $16.48 \pm 0.81$ & $23.36 \pm 0.38$ \\
\hline November (11) & $2.53 \pm 0.32$ & $12.71 \pm 0.86$ & $1015.82 \pm 1.37$ & $16.60 \pm 2.06$ & $51.85 \pm 0.45$ \\
\hline December (12) & $2.80 \pm 0.15$ & $13.84 \pm 0.97$ & $1017.72 \pm 0.75$ & $15.37 \pm 0.98$ & $57.82 \pm 0.40$ \\
\hline \multicolumn{6}{|c|}{ La Niña months } \\
\hline January (1) & $2.50 \pm 0.25$ & $13.98 \pm 0.67$ & $1019.98 \pm 0.75$ & $12.93 \pm 0.64$ & $19.97 \pm 0.07$ \\
\hline February (2) & $2.59 \pm 0.39$ & $13.20 \pm 1.27$ & $1019.66 \pm 2.05$ & $12.57 \pm 0.88$ & $22.98 \pm 0.16$ \\
\hline March (3) & $2.72 \pm 0.36$ & $13.50 \pm 1.4$ & $1017.92 \pm 0.93$ & $12.02 \pm 0.36$ & $19.64 \pm 0.06$ \\
\hline April (4) & $2.16 \pm 0.65$ & $12.12 \pm 0.69$ & $1016.59 \pm 0.96$ & $12.58 \pm 1.10$ & $15.09 \pm 0.04$ \\
\hline May (5) & $2.19 \pm 0.26$ & $10.21 \pm 0.92$ & $1016.34 \pm 0.49$ & $11.91 \pm 0.58$ & $5.86 \pm 0.03$ \\
\hline June (6) & $2.03 \pm 0.00$ & $10.74 \pm 0.00$ & $1014.62 \pm 0.00$ & $12.14 \pm 0.00$ & $19.69 \pm 0.00$ \\
\hline July (7) & $1.64 \pm 0.00$ & $10.67 \pm 1.25$ & $1015.18 \pm 0.77$ & $14.95 \pm 0.67$ & $7.89 \pm 0.06$ \\
\hline August (8) & $1.56 \pm 0.06$ & $9.72 \pm 0.89$ & $1013.73 \pm 1.13$ & $14.75 \pm 0.85$ & $5.86 \pm 0.03$ \\
\hline September (9) & $1.73 \pm 0.09$ & $11.31 \pm 0.90$ & $1013.25 \pm 1.51$ & $15.87 \pm 1.03$ & $12.75 \pm 0.02$ \\
\hline October (10) & $1.94 \pm 0.26$ & $11.67 \pm 1.05$ & $1015.90 \pm 0.70$ & $15.13 \pm 0.11$ & $9.62 \pm 0.02$ \\
\hline November (11) & $2.50 \pm 0.35$ & $13.49 \pm 0.16$ & $1019.26 \pm 0.82$ & $13.81 \pm 0.22$ & $20.95 \pm 0.13$ \\
\hline December (12) & $2.60 \pm 0.40$ & $13.83 \pm 0.36$ & $1021.94 \pm 1.02$ & $12.87 \pm 0.33$ & $29.93 \pm 0.40$ \\
\hline
\end{tabular}

